Prepared in cooperation with the U.S. Department of Energy, National Nuclear Security Administration Nevada Site Office, Office of Environmental Management under Interagency Agreement DE-A152-07NA28100

\title{
Strontium Isotopic Composition of Paleozoic Carbonate Rocks in the Nevada Test Site Vicinity, Clark, Lincoln, and Nye Counties, Nevada, and Inyo County, California
}

Data Series 280 



\section{Strontium Isotopic Composition of Paleozoic Carbonate Rocks in the Nevada Test Site Vicinity, Clark, Lincoln, and Nye Counties, Nevada, and Inyo County, California}

By James B. Paces, Zell E. Peterman, Kiyoto Futa, Thomas A. Oliver, and Brian D. Marshall

Prepared in cooperation with the U.S. Department of Energy National Nuclear Security Administration Nevada Site Office Office of Environmental Management under Interagency Agreement, DE-A152-07NA28100

Data Series 280 


\title{
U.S. Department of the Interior DIRK KEMPTHORNE, Secretary
}

\author{
U.S. Geological Survey \\ Mark D. Myers, Director
}

\section{U.S. Geological Survey, Reston, Virginia: 2007}

For product and ordering information:

World Wide Web: http://www.usgs.gov/pubprod

Telephone: 1-888-ASK-USGS

For more information on the USGS--the Federal source for science about the Earth, its natural and living resources, natural hazards, and the environment:

World Wide Web: http://www.usgs.gov

Telephone: 1-888-ASK-USGS

Any use of trade, product, or firm names is for descriptive purposes only and does not imply endorsement by the U.S. Government.

Although this report is in the public domain, permission must be secured from the individual copyright owners to reproduce any copyrighted materials contained within this report.

Suggested citation:

Paces, J.B., Peterman, Z.E., Futo, Kiyoto, Oliver, T.A., and Marshall, B.D., 2007, Strontium isotopic composition of paleozoic carbonate rocks in the Nevada Test Site vicinity, Clark, Lincoln, and Nye Counties, Nevada, and Inyo County, California: U.S. Geological Survey Data Series 280, 42 p. 


\section{Contents}

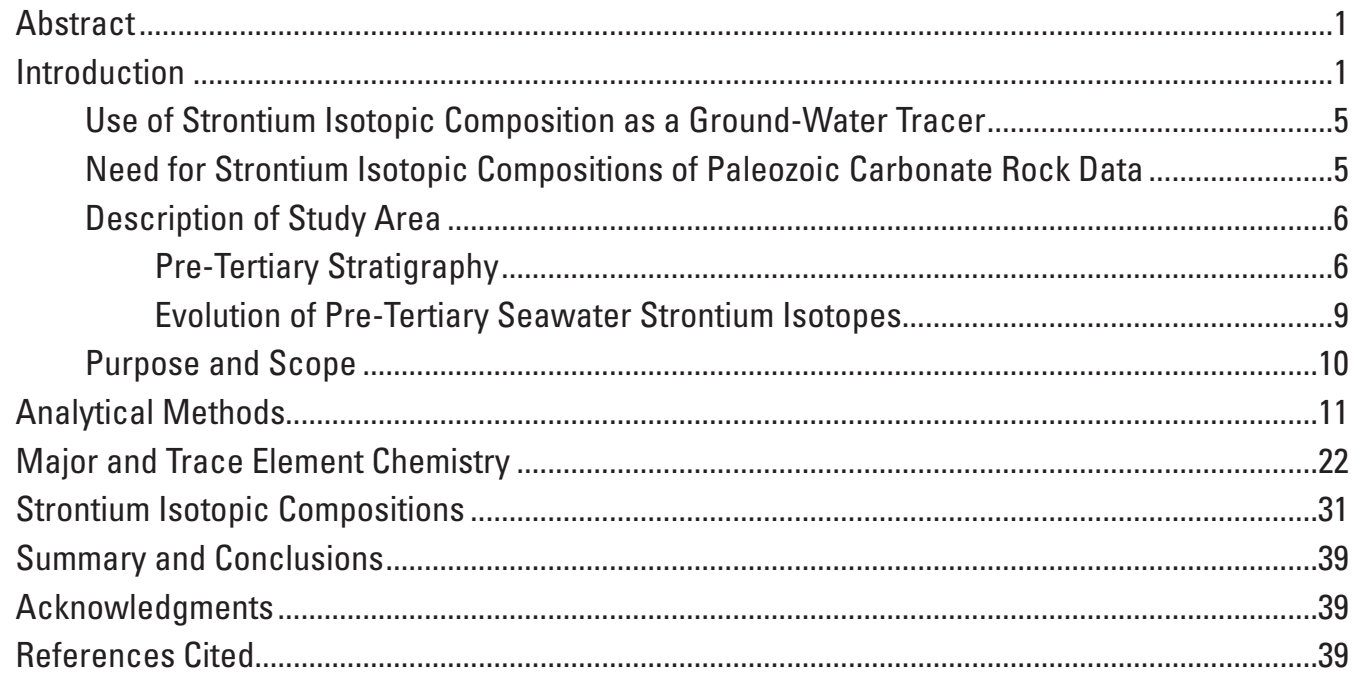

\section{Figures}

Figure 1. Maps showing location of borehole and outcrop samples from the Nevada Test Site region; in and adjacent to the Nevada Test Site; and Bare Mountain and the Funeral Mountains, Clark, Lincoln, and Nye Counties, Nevada, and Inyo County, California

Figure 2. Chart showing principal pre-Tertiary stratigraphic units and associated hydrogeologic units sampled in Nevada Test Site boreholes, Nye County, Nevada

Figure 3. Graph showing variation in strontium isotopic composition $\left({ }^{87} \mathrm{Sr} /{ }^{86} \mathrm{Sr}\right)$ of seawater during part of the Phanerozoic and Neoproterozoic based on analyses of unaltered brachiopods, belemnites, and conodonts from various locations worldwide

Figure 4. Graph showing relation between magnesium oxide $(\mathrm{MgO})$ and calcium oxide $(\mathrm{CaO})$ concentrations in acid leachates of borehole samples, Nevada Test Site, Nye County, Nevada

Figure 5. Graphs showing relation between silic on dioxide $\left(\mathrm{SiO}_{2}\right)$ and aluminum oxide $\left(\mathrm{Al}_{2} \mathrm{O}_{3}\right)$ concentrations and between silicon dioxide and mole percent calcite $\left(\mathrm{CaCO}_{3}\right)$ in acid leachates of borehole samples, Nevada Test Site, Nye County, Nevada

Figure 6. Graph and box-and-whisper plot showing relation between strontium ( $\mathrm{Sr}$ ) concentration and mole percent calcite $\left(\mathrm{CaCO}_{3}\right)$ in acid leachates of borehole samples, and distribution of strontium concentrations for acid leachates, Nevada Test Site, Nye County, Nevada

Figure 7. Graphs showing relation between rubidium $(\mathrm{Rb})$ and silicon dioxide $\left(\mathrm{SiO}_{2}\right)$ concentrations in acid leachates of borehole samples and between rubidium/strontium $(\mathrm{Rb} / \mathrm{Sr}$ ) concentration ratios and mole percent calcite $\left(\mathrm{CaCO}_{3}\right)$ in acid leachates of borehole samples, Nevada Test Site, Nye County, Nevada 


\section{Figures-Continued}

Figure 8. Graphs showing relation between strontium ( $\mathrm{Sr}$ ) and zirconium $(\mathrm{Zr})$ concentrations, strontium and rubidium $(\mathrm{Rb})$ concentrations, zirconium and rubidium concentrations for bulk-rock outcrop samples, and the frequency distribution of strontium concentrations for bulk-rock outcrop samples with zirconium concentrations less than or equal to 20 micrograms per gram, Nevada Test Site and adjacent areas, Clark, Lincoln, and Nye Counties, Nevada, and Inyo

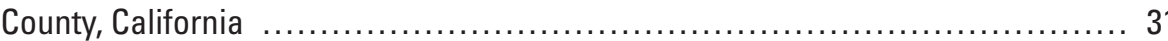

Figure 9. Frequency distribution plots for strontium isotopic compositions $\left({ }^{87} \mathrm{Sr} /{ }^{86} \mathrm{Sr}\right)$ measured in borehole and outcrop samples, Nevada Test Site and adjacent areas, Clark, Lincoln, and Nye Counties, Nevada, and Inyo County, California 33

Figure 10. Graphs showing relation between strontium isotopic compositions $\left({ }^{87} \mathrm{Sr} /{ }^{86} \mathrm{Sr}\right)$ and reciprocal strontium concentrations for acid leachates of borehole samples and ${ }^{87} \mathrm{Sr} /{ }^{86} \mathrm{Sr}$ and silicon dioxide $\left(\mathrm{SiO}_{2}\right)$ concentrations for acid leachates of borehole samples, Nevada Test Site, Nye County, Nevada

Figure 11. Graphs showing relation between ${ }^{87} \mathrm{Sr}_{t^{\prime}}$ and depositional age for acid leachates of borehole and outcrop samples, Nevada Test Site and adjacent areas, Clark, Lincoln, and Nye Counties, Nevada, and Inyo County, California

Figure 12. Maps showing spatial distribution of ${ }^{87} \mathrm{Sr}_{\mathrm{t}^{\prime}}$ values for borehole and outcrop samples from the Nevada Test Site vicinity, and in and adjacent to the eastern part of the Nevada Test Site, Clark, Lincoln, and Nye Counties, Nevada, and Inyo County, California

\section{Tables}

Table 1. Ages and seawater strontium isotopic composition $\left({ }^{87} \mathrm{Sr} /{ }^{86} \mathrm{Sr}\right)$ of stratigraphic units present in the Nevada Test Site region, southern Nevada

Table 2. Locations of boreholes from which core samples were obtained the Nevada Test Site, Nye County, Nevada

Table 3. Description of samples analyzed for strontium isotopic compositions from boreholes at the Nevada Test Site, Nye County, Nevada

Table 4. Locations, stratigraphic unit designations, and descriptions of outcrop samples analyzed for strontium isotopic compositions from the Nevada Test Site vicinity, Clark, Lincoln, and Nye Counties, Nevada, and Inyo County, California

Table 5. Oxide and elemental concentrations and strontium isotopic compositions $\left({ }^{87} \mathrm{Sr} /{ }^{36} \mathrm{Sr}\right)$ of nitric-acid leachates of core samples from boreholes at the Nevada Test Site, Nye County, Nevada

Table 6. Bulk-rock analyses of selected trace element concentrations and strontium isotopic compositions ${ }^{87} \mathrm{Sr} /{ }^{86} \mathrm{Sr}$ ) in outcrop samples collected in the early $1990 \mathrm{~s}$ from the Nevada Test Site vicinity, Clark, Lincoln, and Nye Counties, Nevada, and Inyo County, California

Table 7. Selected trace element concentrations and strontium isotopic compositions $\left({ }^{87} \mathrm{Sr} /{ }^{86} \mathrm{Sr}\right)$ in core samples from boreholes UE-25 a \#3 and UE-25 $\mathrm{p} \# 1$, Nevada Test Site, Nye County, Nevada 


\section{Conversion Factors, Datum, Definitions, and Abbreviations and Acronyms}

Conversion Factors

\begin{tabular}{lll}
\hline Multiply & \multicolumn{1}{c}{ By } & To obtain \\
\hline centimeter $(\mathrm{cm})$ & 0.3937 & inch \\
gram $(\mathrm{g})$ & 0.03527 & ounce, avoirdupois \\
kilometer $(\mathrm{km})$ & 0.6214 & mile \\
meter $(\mathrm{m})$ & 3.281 & foot \\
meter $(\mathrm{m})$ & 1.094 & yard \\
millimeter $(\mathrm{mm})$ & 0.03937 & inch \\
square kilometer $\left(\mathrm{km}^{2}\right)$ & 0.6124 & square mile \\
\hline
\end{tabular}

Temperature in degrees Celsius $\left({ }^{\circ} \mathrm{C}\right)$ may be converted to degrees Fahrenheit $\left({ }^{\circ} \mathrm{F}\right)$ as follows:

$$
{ }^{\circ} \mathrm{F}=\left(1.8 x^{\circ} \mathrm{C}\right)+32 \text {. }
$$

Datum

Horizontal coordinates convention: Horizontal coordinates, given in meters, are referenced to the Universal Transverse Mercator (UTM) system of Easting (X coordinate) and Northing ( $Y$ coordinate) distances within Zone 11 and are based on the North American datum of 1927 (NAD27).

\section{Definitions}

Isotope notation conventions: Strontium isotopic compositions are given as both atomic ratios of ${ }^{87} \mathrm{Sr} /{ }^{86} \mathrm{Sr}$ as well as delta strontium-87 $\left(\delta^{87} \mathrm{Sr}\right)$ calculated using the formula:

$$
\delta^{87} \mathrm{Sr}=\left[\left({ }^{87} \mathrm{Sr} /{ }^{86} \mathrm{Sr}_{\text {sample }}{ }^{87} \mathrm{Sr} /{ }^{86} \mathrm{Sr} r_{\text {msw }}\right)-1\right] \times 1000,
$$

where ${ }^{87} \mathrm{Sr} /{ }^{86} \mathrm{Sr}_{\text {msw }}$ is the value for modern sea water (msw) of 0.70920 , and the resulting value is in parts per thousand or per mil (\%o). In addition, delta strontium- 87 can be calculated using the value for seawater ${ }^{87} \mathrm{Sr} /{ }^{86} \mathrm{Sr}$ at the time of rock deposition and is designated as $\delta^{87} \mathrm{Sr}_{\mathrm{t}}$

Geochronological conventions: Abbreviations used to designate geologic time in this report are mega-annum (Ma) to specify a specific time in millions of years before the present, and millions of years (m.y.) to specify the duration of a remote time interval.

Units of concentration: Concentrations of chemical constituents measured in unknown rock samples are given in weight percent (parts per hundred, abbreviated by wt. \%) for major elements in the form of oxides, and micrograms per gram (parts per million, abbreviated by $\mu \mathrm{g} / \mathrm{g}$ ) for trace elements. Concentrations of acids used to digest the carbonate fraction of rock samples are given in Molarity units equal to the number of moles of a solute per liter of solvent (abbreviated as M). 
Abbreviations and Acronyms

\begin{tabular}{ll}
\hline Abbreviation & Chemical Species \\
$\mathrm{Al}_{2} \mathrm{O}_{3}$ & aluminum oxide, or alumina \\
$\mathrm{Ba}$ & barium \\
$\mathrm{CaO}$ & calcium oxide \\
$\mathrm{CaCO}$ & calcium carbonate (calcite) \\
$\mathrm{Ce}$ & cerium \\
$\mathrm{La}$ & lanthanum \\
$\mathrm{MgO}$ & magnesium oxide \\
$\mathrm{MnO}$ & manganese oxide \\
$\mathrm{Nb}$ & niobium \\
$\mathrm{SiO}$ & silicon dioxide \\
$\mathrm{Rb}$ & rubidium \\
$\mathrm{Sr}$ & strontium \\
$\mathrm{Th}$ & thorium \\
$\mathrm{U}$ & uranium \\
$\mathrm{Y}$ & yittrium \\
$\mathrm{Zr}$ & zirconium \\
\hline Acronym & Definition \\
\hline $\mathrm{DOE}$ & U.S. Department of Energy \\
ICP-MS & Inductively coupled plasma mass spectrometry \\
LCA & lower carbonate aquifer \\
$\mathrm{NTS}$ & Nevada Test Site \\
$\mathrm{SRM}$ & Standard Reference Material \\
USGS & U.S. Geological Survey \\
XRF & X-ray fluorescence \\
\hline & \\
\hline
\end{tabular}




\title{
Strontium Isotopic Composition of Paleozoic Carbonate Rocks in the Nevada Test Site Vicinity, Clark, Lincoln, and Nye Counties, Nevada, and Inyo County, California
}

\author{
By James B. Paces, Zell E. Peterman, Kiyoto Futa, Thomas A. Oliver, and Brian D. Marshall
}

\begin{abstract}
Ground water moving through permeable Paleozoic carbonate rocks represents the most likely pathway for migration of radioactive contaminants from nuclear weapons testing at the Nevada Test Site, Nye County, Nevada. The strontium isotopic composition $\left({ }^{87} \mathrm{Sr} /{ }^{86} \mathrm{Sr}\right)$ of ground water offers a useful means of testing hydrochemical models of regional flow involving advection and reaction. However, reaction models require knowledge of ${ }^{87} \mathrm{Sr} /{ }^{86} \mathrm{Sr}$ data for carbonate rock in the Nevada Test Site vicinity, which is scarce. To fill this data gap, samples of core or cuttings were selected from 22 boreholes at depth intervals from which water samples had been obtained previously around the Nevada Test Site at Yucca Flat, Frenchman Flat, Rainier Mesa, and Mercury Valley. Dilute acid leachates of these samples were analyzed for a suite of major- and trace-element concentrations $\left(\mathrm{MgO}, \mathrm{CaO}, \mathrm{SiO}_{2}, \mathrm{Al}_{2} \mathrm{O}_{3}, \mathrm{MnO}, \mathrm{Rb}, \mathrm{Sr}\right.$, $\mathrm{Th}$, and $\mathrm{U}$ ) as well as for ${ }^{87} \mathrm{Sr} /{ }^{86} \mathrm{Sr}$. Also presented are unpublished analyses of 114 Paleozoic carbonate samples from outcrops, road cuts, or underground sites in the Funeral Mountains, Bare Mountain, Striped Hills, Specter Range, Spring Mountains, and ranges east of the Nevada Test Site measured in the early 1990 's. These data originally were collected to evaluate the potential for economic mineral deposition at the potential high-level radioactive waste repository site at Yucca Mountain and adjacent areas (Peterman and others, 1994). Samples were analyzed for a suite of trace elements $(\mathrm{Rb}, \mathrm{Sr}, \mathrm{Zr}, \mathrm{Ba}, \mathrm{La}$, and $\mathrm{Ce}$ ) in bulk-rock powders, and ${ }^{87} \mathrm{Sr} /{ }^{86} \mathrm{Sr}$ in partial digestions of carbonate rock using dilute acid or total digestions of silicaterich rocks. Pre-Tertiary core samples from two boreholes in the central or western part of the Nevada Test Site also were analyzed. Data are presented in tables and summarized in
\end{abstract}

graphs; however, no attempt is made to interpret results with respect to ground-water flow paths in this report. Present-day ${ }^{87} \mathrm{Sr} r{ }^{86} \mathrm{Sr}$ values are compared to values for Paleozoic seawater present at the time of deposition. Many of the samples have ${ }^{87} \mathrm{Sr} /{ }^{86} \mathrm{Sr}$ compositions that remain relatively unmodified from expected seawater values. However, rocks underlying the northern Nevada Test Site as well as rocks exposed at Bare Mountain commonly have elevated ${ }^{87} \mathrm{Sr} /{ }^{86} \mathrm{Sr}$ values derived from post-depositional addition of radiogenic Sr most likely from fluids circulating through rubidium-rich Paleozoic strata or Precambrian basement rocks.

\section{Introduction}

The Nevada Test Site (NTS), occupying approximately $3,500 \mathrm{~km}^{2}$ in southern Nevada (fig. 1), has been the primary site for underground testing of nuclear weapons by the United States since the late 1950's. Radioactive byproducts have been emplaced above and below the regional water table as a result of this testing (Laczniak and others, 1996, p. 2). In an effort to understand the movement of these radioactive contaminants (radionuclides) away from areas of underground testing, the U.S. Department of Energy (DOE) has established an Environmental Restoration Program to investigate the hydrologic pathways and travel times associated with regional ground-water flow beneath the NTS and vicinity (U.S. Department of Energy, 1991, p. 2). Fractures in Middle Cambrian through Devonian limestones and dolomites constituting the regional lower carbonate aquifer (LCA) are the most likely pathways for the transport of radioactive nuclides (Winograd and Thordarson, 1975, p. 119; Laczniak and others, 1996, p. 15). 


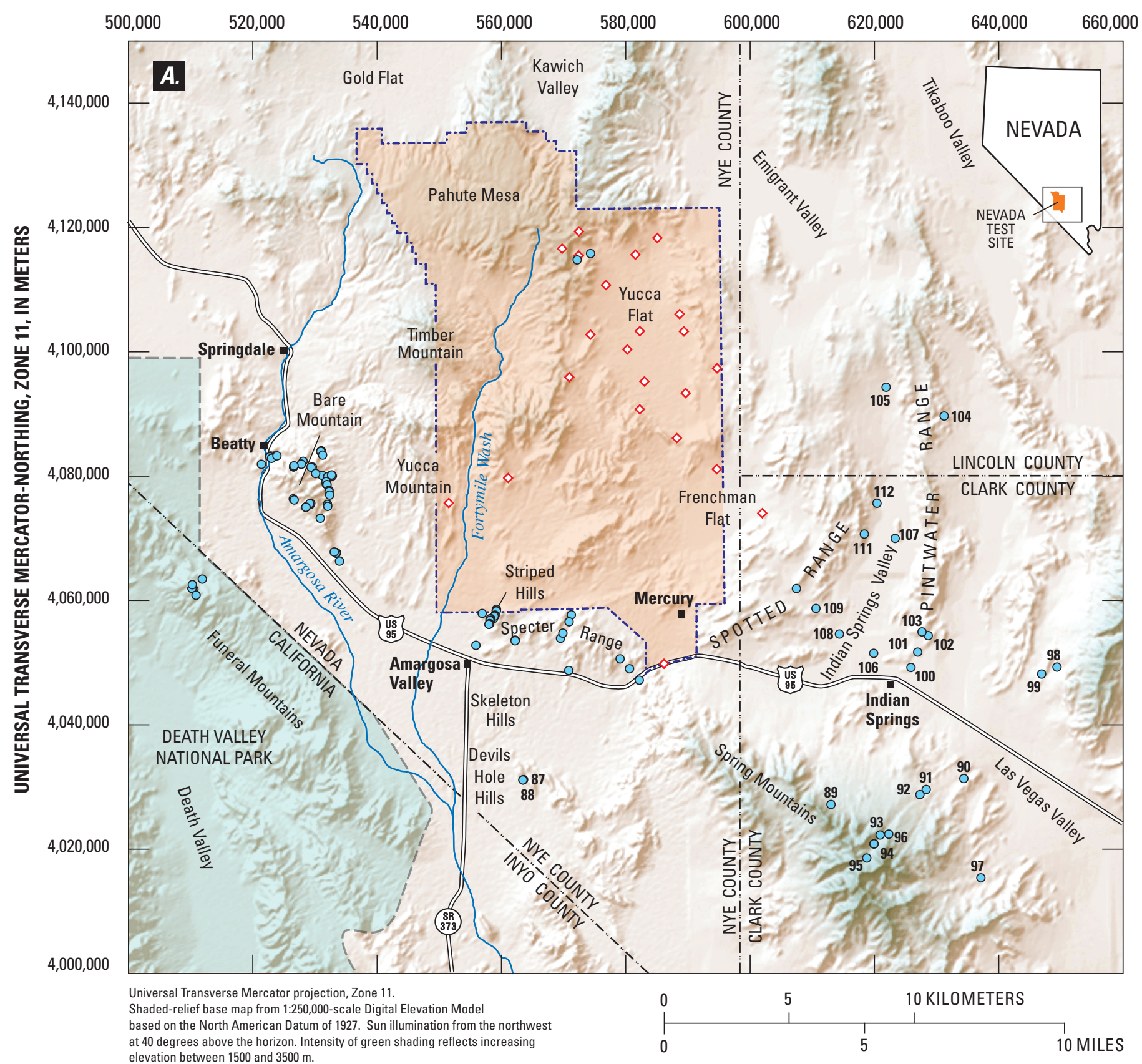

UNIVERSAL TRANSVERSE MERCATOR-EASTING, ZONE 11, IN METERS

\section{EXPLANATION}

- - - Nevada Test Site boundary

$\diamond$ Borehole (with or without borehole identification No.)

${ }_{89}{ }^{\circ}$ Outcrop (with or without borehole identification No.)

Figure 1. Location of borehole and outcrop samples from $(A)$ the Nevada Test Site region; $(B)$ in and adjacent to the Nevada Test Site; and $(C)$ Bare Mountain and the Funeral Mountains, Clark, Lincoln, and Nye Counties, Nevada, and Inyo County, California. Boreholes and outcrop sites without labels in figure $1 A$ are identified in figures $1 B$ or $1 C$. Map numbers for outcrop samples are keyed to tables 4 and $\underline{6}$. 


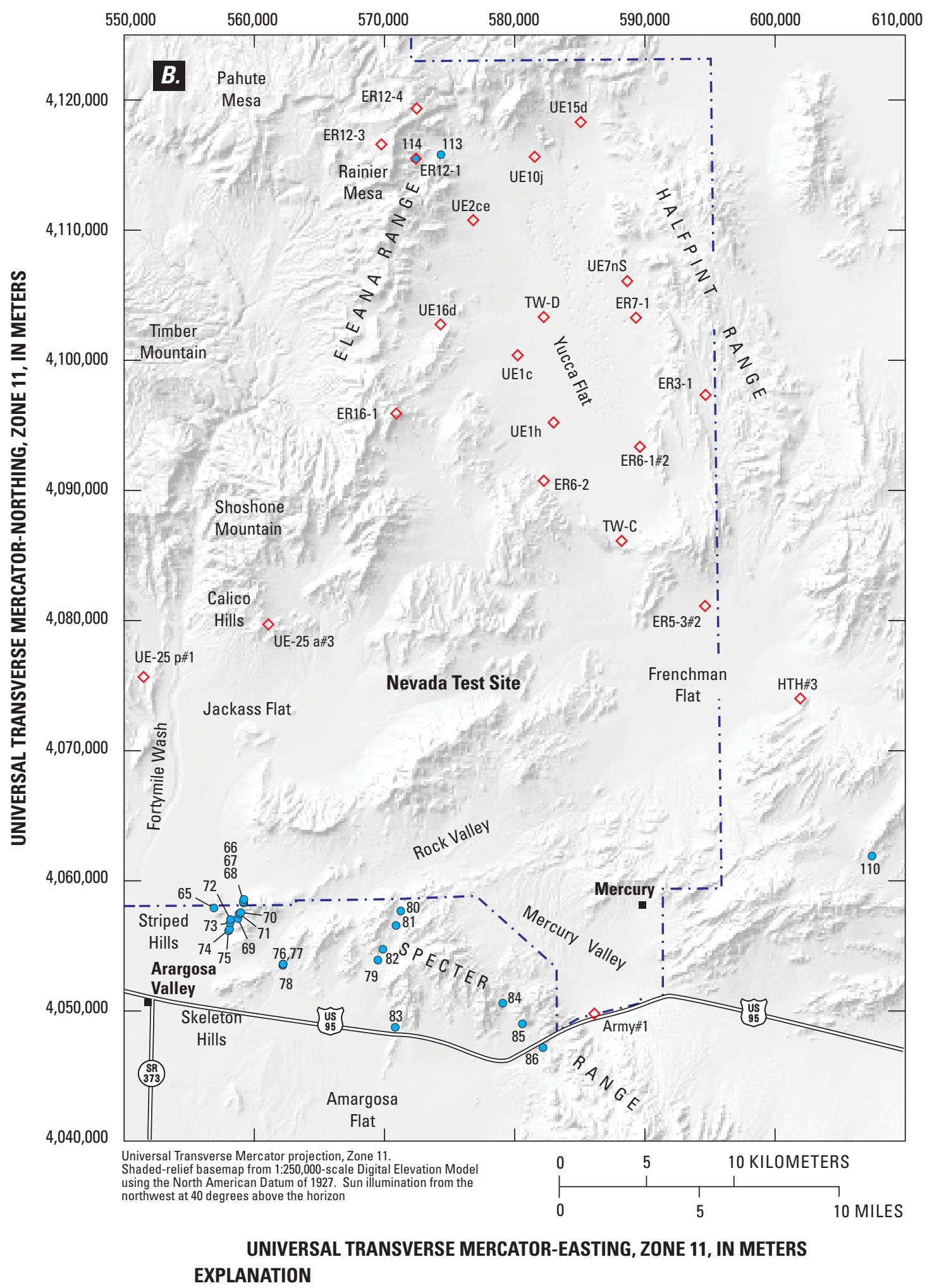

- . - Nevada Test Site boundary

TW-C $\diamond$ Borehole (with borehole identification No.)

${ }_{89} \mathrm{O}$ Outcrop (with map No.)

Figure 1. Continued. 


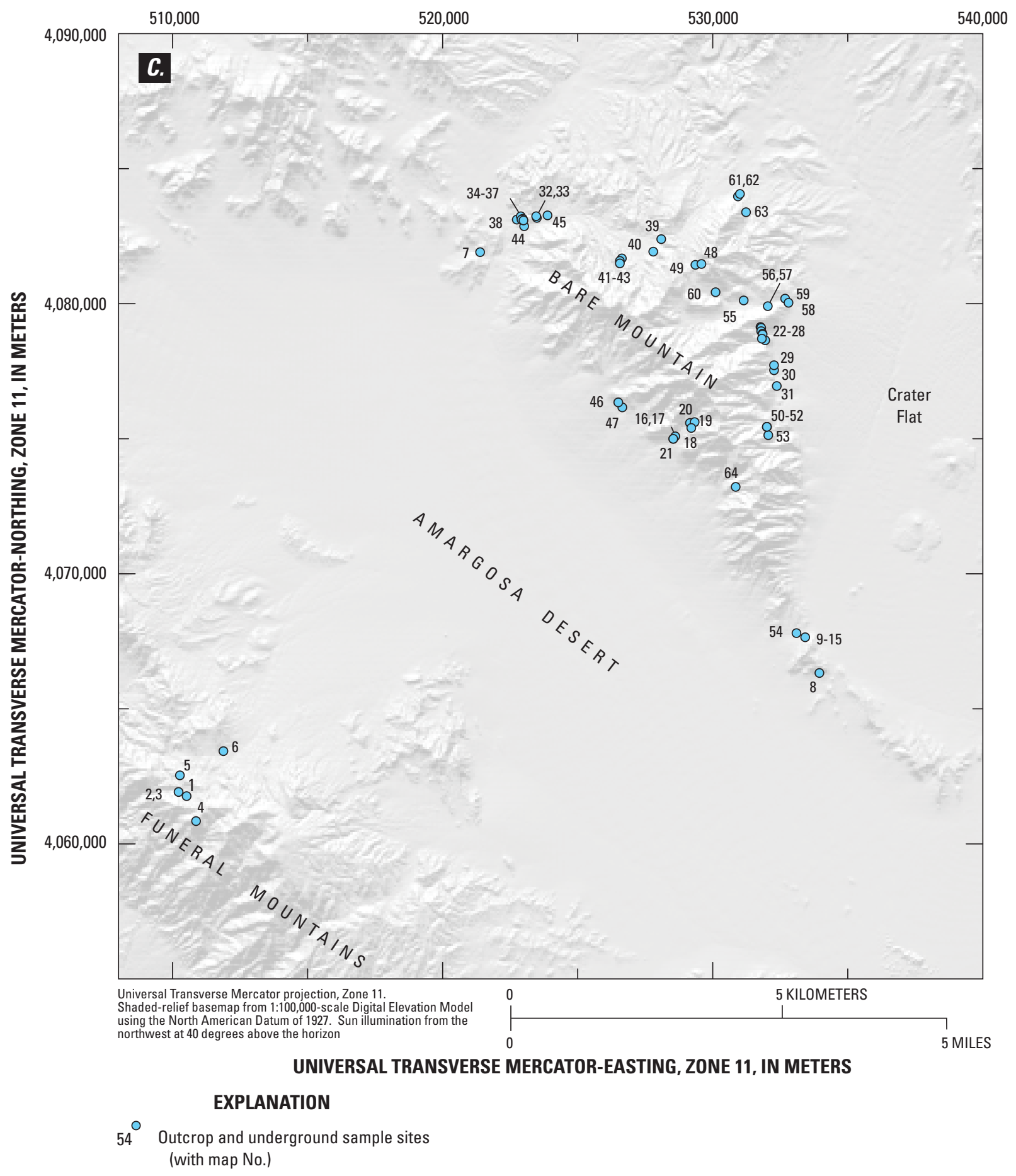

Figure 1. Continued. 
Geochemical and isotopic data from ground-water samples are being used to evaluate possible ground-water flow paths in the DOE Environmental Restoration Program (Thomas and others, 2002; Hershey and others, 2005; Rose and others, 2006; Farnham and others, 2006). Conservative tracers (isotopes or elements that undergo negligible modification by water-rock interaction) typically are used to delineate ground-water flow paths and evaluate mixing of water masses from upgradient sources. These tracers are combined with other dissolved constituents in advectionreaction geochemical modeling (NETPATH, PHREEQC) to evaluate chemical evolution along postulated ground-water flow paths. However, to understand the potential contributions of rock and mineral constituents, chemical compositions of aquifer components are required as inputs in geochemical models. Isotope tracers of geochemical processes can help discriminate between alternative flow models whose solutions may remain non-unique based on chemical concentrations alone. Like other chemical constituents, an understanding of the range of compositions in both water and rock is required for constraining flow paths and for evaluating possible aquiferwater interactions.

\section{Use of Strontium Isotopic Composition as a Ground-Water Tracer}

The isotopic composition of strontium $\left({ }^{87} \mathrm{Sr} /{ }^{86} \mathrm{Sr}\right)$ can be used as a natural tracer of ground-water flow because the strontium ion $\left(\mathrm{Sr}^{+2}\right)$ is soluble in aqueous solutions at levels allowing high-precision isotope measurement, because variations in rubidium-to-strontium $(\mathrm{Rb} / \mathrm{Sr})$ ratios in rocks of different type and petrogenetic origin result in distinctive ${ }^{87} \mathrm{Sr} /{ }^{86} \mathrm{Sr}$ ground-water signatures, and because fractionation of heavy radiogenic isotopes ${ }^{87} \mathrm{Sr}$ from ${ }^{86} \mathrm{Sr}$ ) is negligible for geologic processes (Peterman and Stuckless, 1992; McNutt, 2000). However, unlike conservative tracers, ${ }^{87} \mathrm{Sr} /{ }^{86} \mathrm{Sr}$ values can be modified along ground-water flow paths by reaction with the aquifer rock. Studies have shown that $\mathrm{Sr}$ dissolved in ground water may not be in isotopic equilibrium with the aquifer through which it flows (Peterman and Stuckless, 1992, and references therein). This disequilibrium commonly provides important insight into the ground-water flow system for which conceptual models may otherwise be oversimplified. For example, in several carbonate aquifer studies, ${ }^{87} \mathrm{Sr} /{ }^{86} \mathrm{Sr}$ ratios in ground-water samples are larger than those of the aquifer rock (Chaudhuri and others, 1987; Banner and others, 1989, p. 396; McKenna and others, 1992; Peterman and others, 1992, p. 827; Frost and Toner, 2004). This disequilibrium requires ground-water contributions from associated Precambrian rocks having higher ${ }^{87} \mathrm{Sr} /{ }^{86} \mathrm{Sr}$ signatures, but which typically were considered to be impermeable.
The behavior of $\mathrm{Sr}$ and ${ }^{87} \mathrm{Sr} /{ }^{86} \mathrm{Sr}$ in ground-water flow systems depends on numerous factors including length of flow path, water-to-rock mass ratio, chemical reaction rates, $\mathrm{Sr}$ concentration and ${ }^{87} \mathrm{Sr} /{ }^{86} \mathrm{Sr}$ in solid and fluid phases, flow velocity, advective fluid mixing, dispersion, and ion exchange (Johnson and DePaolo, 1994, 1997). In aquifers dominated by fracture flow, the $\mathrm{Sr}$ isotopic composition of water is less likely to be modified by changes in rock ${ }^{87} \mathrm{Sr} /{ }^{86} \mathrm{Sr}$ values along a flow path than in aquifers dominated by matrix flow because of faster flow velocities, larger water-to-rock mass ratios, and slower reaction rates (Johnson and others, 2000). Therefore, in aquifers dominated by fracture flow or high permeability matrix flow, such as alluvium, $\mathrm{Sr}$ may be useful as a tracer of water from upgradient sources (Johnson and DePaolo, 1994, p. 1576), at least at path lengths commensurate with the scale of the NTS.

Chemical processes resulting in nonconservative behavior of $\mathrm{Sr}$ in ground water affect $\mathrm{Sr}$ concentrations to a greater extent than ${ }^{87} \mathrm{Sr} r{ }^{86} \mathrm{Sr}$ values. Losses of $\mathrm{Sr}$ from solution due to sorption and mineral precipitation will not change the ${ }^{87} \mathrm{Sr} /{ }^{86} \mathrm{Sr}$ ratio in the remaining fluid. Furthermore, desorption or cation exchange from reactive mineral surfaces along flow paths may not significantly affect ${ }^{87} \mathrm{Sr} /{ }^{86} \mathrm{Sr}$ values if the dynamics of flow and sources of $\mathrm{Sr}$ have remained unchanged over long periods (steady-state flow conditions). In contrast, rock dissolution can add $\mathrm{Sr}$ containing very different isotopic compositions to solution, particularly if ground water that is unsaturated, with respect to calcite or dolomite, flows into the LCA.

\section{Need for Strontium Isotopic Compositions of Paleozoic Carbonate Rock Data}

Use of ${ }^{87} \mathrm{Sr} /{ }^{86} \mathrm{Sr}$ as a tracer in advection-reaction geochemical models of ground-water flow in the LCA requires knowledge of rock $\mathrm{Sr}$ concentrations and ${ }^{87} \mathrm{Sr} /{ }^{86} \mathrm{Sr}$ compositions. The structures of minerals constituting marine carbonate deposits result in rocks with relatively high $\mathrm{Sr}$ concentrations and low $\mathrm{Rb}$ concentration. Therefore, the ${ }^{87} \mathrm{Sr} /{ }^{86} \mathrm{Sr}$ values inherited from seawater will not change appreciably with time due to the decay of ${ }^{87} \mathrm{Rb}$. However, previous studies demonstrated that at least some Paleozoic carbonate rocks in the NTS vicinity have nonmarine ${ }^{87} \mathrm{Sr} /{ }^{86} \mathrm{Sr}$ compositions indicating that radiogenic ${ }^{87} \mathrm{Sr}$ from crustal sources was introduced into the carbonate rocks at some time in the past (Peterman and others, 1994; J. Kenneally, Lawrence Livermore National Laboratory, written commun., 1995). These studies indicate that Paleozoic carbonate rocks at the NTS can have a much wider range of ${ }^{87} \mathrm{Sr} /{ }^{86} \mathrm{Sr}$ values that are more radiogenic than values derived from a seawater origin. 
Ground water flowing through the LCA on the east side of the NTS commonly has ${ }^{87} \mathrm{Sr} /{ }^{86} \mathrm{Sr}$ values that are greater than values expected from seawater sources (Hershey and others, 2005; Farnham and others, 2006). Advection-reaction geochemical models of ground-water evolution between sample sites commonly require small amounts of mineral dissolution that would likely affect the ${ }^{87} \mathrm{Sr} /{ }^{86} \mathrm{Sr}$ of dissolved $\mathrm{Sr}$ in the water. However, because ${ }^{87} \mathrm{Sr} /{ }^{86} \mathrm{Sr}$ compositions of most carbonate rocks on the NTS generally are not available, the influence of water-rock reaction during chemical evolution along flow paths cannot be evaluated effectively. Therefore, it is necessary to better constrain rock ${ }^{87} \mathrm{Sr} /{ }^{86} \mathrm{Sr}$ values present along potential flow paths to more reliably utilize ${ }^{87} \mathrm{Sr} /{ }^{86} \mathrm{Sr}$ as a ground-water tracer.

\section{Description of Study Area}

Because ground-water flow through the LCA represents the most likely scenario for transporting radionuclides beyond the eastern and southern boundaries of the NTS, characterization of ${ }^{87} \mathrm{Sr} /{ }^{86} \mathrm{Sr}$ in Paleozoic carbonate rocks constitutes the focus of this study. A small number of older carbonate rocks as well as a few samples of Paleozoic silicate rocks are also included. Most rocks constituting the LCA were deposited as chemical precipitates from Paleozoic seawater. Because this reservoir is well mixed on a global scale by vertical and lateral circulation patterns, its $\mathrm{Sr}$ isotope evolution has been well documented by examining samples from many other areas. Both the stratigraphy of pre-Tertiary rocks and the evolution of seawater ${ }^{87} \mathrm{Sr} /{ }^{86} \mathrm{Sr}$ are described in the following sections.

\section{Pre-Tertiary Stratigraphy}

Pre-Tertiary rocks of southeastern Nevada consist of a thick sequence of older (Neoproterozoic to Devonian in age) shallow-water marine sediments deposited in a miogeoclinal (passive continental shelf) environment and younger (Devonian to Mississippian in age) marine sediments deposited in a foreland basin along the Cordilleran continental margin. A generalized stratigraphic succession of the approximately 11,500-m-thick sequence of preTertiary rocks present on the NTS is shown in figure 2. The summary presented below is compiled from more detailed descriptions presented by Burchfiel (1964), Barnes and Christiansen (1967), Stewart and Poole (1974), Winograd and Thordarson (1975), Monsen and others (1992), Laczniak and others (1996), Trexler and others (1996; 2003), Slate and others (1999), and Page and others (2005). Age estimates for stratigraphic units from the NTS and surrounding areas are listed in table 1.
The oldest sedimentary rocks on the NTS consist of a 2,800-m-thick series of Neoproterozoic and lower Cambrian deposits dominated by marine clastic sediments (quartzite, arkose, siltstone, and shale/argillite). Silty carbonate units, such as the Noonday Dolomite and dolomitic units in the Wood Canyon and Johnnie Formations, are present locally in this sequence. The well-cemented to moderately metamorphosed rocks of this sequence generally are considered to be poor transmitters of ground-water flow and constitute the lower clastic confining unit of Winograd and Thordarson (1975). The Lower-to-Middle Cambrian Carrara Formation contains siltstone and shale with thin, but persistent, limestone beds that become more common upsection. These time-transgressive lithologic changes reflect the regional transition to a depositional environment dominated by marine carbonate sedimentation.

The 5,200-m-thick section of Middle Cambrian through Devonian rocks is composed of marine limestones and dolomites with minor interbeds of sandy or silty clastic units (Barnes and Christiansen, 1967; Stewart and Poole, 1974; Trexler and others, 1996, 2003; Slate and others, 1999). Aquifer tests indicate very high degrees of water transmissivity through these units due to extensive secondary permeability along a well-connected network of solutionenhanced fractures, faults, and breccias (Winograd and Thordarson, 1975, p. 117; Laczniak and others, 1996). Collectively, these rocks constitute the LCA and provide the main pathways for ground-water flow between Tertiary basins. Because the few clastic units within this sequence (Dunderberg Shale Member of the Nopah Formation, the Ninemile Formation of the Pogonip Group, and the Eureka Quartzite) are thin and structurally disrupted, they do not constitute regionally effective confining units, though they may impede flow locally (Laczniak and others, 1996, p. 15).

Mississippian strata overlying Devonian and older carbonates of the LCA are mostly clastic rocks (conglomeritic sandstone, siltstone, shale, bioclastic limestone, and rare quartzite) to the west of Yucca Flat and carbonate to the east of the NTS (Winograd and Thordarson, 1975, p. 9; Trexler and others, 1996, 2003). These rocks reflect a change from sedimentation along a passive continental margin to clastic-dominated depositional environments in foreland basins associated with convergent tectonics of the Antler orogeny (Poole, 1974; Cole and others, 1997; Cole and Cashman, 1999; Trexler and others, 2003). Up to 3,000 m of predominantly synorogenic siliciclastic rocks constitute the Late Devonian to Middle Mississippian Eleana Formation and laterally equivalent Gap Wash Formation as well as the overlying Late Mississippian Chainman Shale/Captain Jack Formations (Cole and Cashman, 1999; Trexler and others, 2003). 


\begin{tabular}{|c|c|c|c|c|}
\hline Rock system & \multicolumn{2}{|c|}{ Stratigraphic unit } & Abbreviation & Hydrogeologic unit \\
\hline \multirow{2}{*}{ Tertiary } & \multicolumn{3}{|c|}{ Valley-fill deposits } & Alluvial aquifer \\
\hline & \multicolumn{3}{|c|}{ Volcanic rocks } & Volcanic aquifers and confining units \\
\hline Lower Permian \& Pennsylvanian & \multicolumn{2}{|c|}{ Tippipah Limestone } & PPt & Upper carbonate-rock aquifer \\
\hline \multirow[b]{2}{*}{ Mississippian and upper Devonian } & \multicolumn{2}{|c|}{ Chainman Shale } & Mc & \\
\hline & \multicolumn{2}{|c|}{$\begin{array}{l}\text { Gap Wash Formation } \\
\text { Eleana Formation }\end{array}$} & $\begin{array}{l}\mathrm{MDg} \\
\mathrm{MDe}\end{array}$ & Upper clastic confining unit \\
\hline \multirow{3}{*}{ Devonian } & \multicolumn{2}{|c|}{ Guilmette Formation } & $\mathrm{Dg}$ & \multirow{17}{*}{ Lower carbonate-rock aquifer } \\
\hline & \multicolumn{2}{|c|}{ Simonson Dolomite } & Dsi & \\
\hline & \multicolumn{2}{|c|}{ Sevy Dolomite } & Dsv & \\
\hline Devonian and Silurian & \multicolumn{2}{|c|}{ Lone Mountain Dolomite } & DSIm & \\
\hline \multirow{2}{*}{ Silurian } & \multicolumn{2}{|c|}{ Roberts Mountains Formation } & $\mathrm{Sr}$ & \\
\hline & \multicolumn{2}{|c|}{ Laketown Dolomite } & SI & \\
\hline \multirow{5}{*}{ Ordovician } & \multicolumn{2}{|c|}{ Ely Springs Dolomite } & Oes & \\
\hline & \multicolumn{2}{|c|}{ Eureka Quartzite } & Oeq & \\
\hline & \multirow{3}{*}{ Pogonip Group } & Antelope Valley Limestone & Op-av & \\
\hline & & Ninemile Formation & Op-n & \\
\hline & & Goodwin Limestone & Op-g & \\
\hline \multirow{7}{*}{ Cambrian } & \multirow{3}{*}{ Nopah Formation } & Smoky Member & $€ n-s$ & \\
\hline & & Halfpint Member & $€ n-h$ & \\
\hline & & Dunderberg Shale Member & $€ n-d$ & \\
\hline & \multirow{2}{*}{$\begin{array}{l}\text { Bonanza King } \\
\text { Formation }\end{array}$} & Banded Mountain Member & $€ b b$ & \\
\hline & & Papoose Lake Member & $€ b p$ & \\
\hline & \multirow{2}{*}{ Carrara Formation } & Upper part & $€ c-u$ & \\
\hline & & Lower part & $€ c-1$ & \multirow{4}{*}{ Lower clastic confining unit } \\
\hline Cambrian and Neoproterozoic & Wood C & anyon Formation & $€ Z w$ & \\
\hline \multirow{3}{*}{ Neoproterozoic } & \multicolumn{2}{|c|}{ Stirling Quartzite } & Zs & \\
\hline & \multicolumn{2}{|c|}{ Johnnie Formation } & $\mathrm{Zj}$ & \\
\hline & \multicolumn{2}{|c|}{ Noonday Dolomite } & $\mathrm{Zn}$ & Not classified \\
\hline
\end{tabular}

Figure 2. Principal pre-Tertiary stratigraphic units and associated hydrogeologic units sampled in Nevada Test Site boreholes, Nye County, Nevada. 
Table 1. Ages and seawater strontium isotopic composition $\left({ }^{87} \mathrm{Sr} /{ }^{86} \mathrm{Sr}\right)$ of stratigraphic units present in the Nevada Test Site region, southern Nevada.

[Stratigraphic units and epochs are from the U.S. Geological Survey Geologic Names Lexicon database (http://ngmdb.usgs.gov/Geolex/geolex home.html). Age assignments are based on the time scale of Young and Laurie (1996), which McArthur and others (2001) used to construct the Paleozoic seawater curve (fig. 3). Maximum, minimum, and mean Sr isotopic compositions are determined from values shown in figure 3 averaged over the time period given. Age ranges are given in millions of years before present (m.y.)]

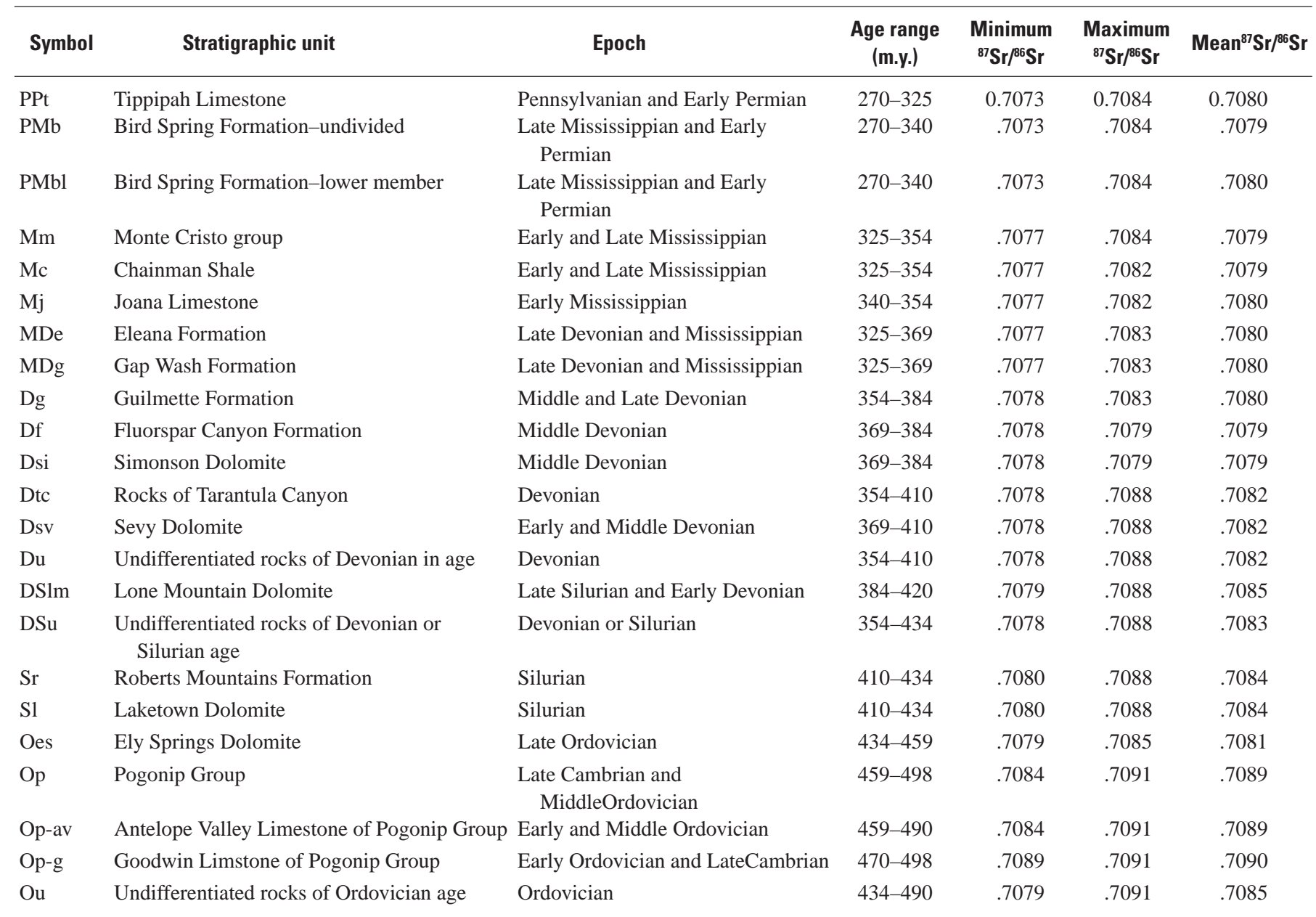

Although silty carbonate beds present in the Late Mississippian Captain Jack Formation (and, to a lesser extent, Chainman Shale) reflect a return to shallow-water marine environments, the thick siliciclastic sediments have low permeability and form the upper clastic confining unit in western Yucca Flat and Jackass Flat that isolates most regional ground-water flow in the LCA (Winograd and Thordarson, 1975, p. 43). Approximately $1,100 \mathrm{~m}$ of Pennsylvanian to early Permian Tippipah Limestone are preserved in two localities in the central NTS that unconformably overlie muddy shelf deposits of the Chainman Shale (Cole and Cashman, 1999). Winograd and Thordarson (1975, p. 30) included these rocks in the upper-carbonate-rock aquifer, but recognized their restricted distribution within the saturated zone and the limited role of the upper carbonate aquifer in regional ground-water movement. East of the NTS, the upper clastic confining unit is not present and Paleozoic carbonate rocks, regardless of age, form a single regional carbonate-rock aquifer (Laczniak and others, 1996, p. 15). 
Table 1. Ages and seawater strontium isotopic composition $\left({ }^{87} \mathrm{Sr} /{ }^{86} \mathrm{Sr}\right)$ of stratigraphic units present in the Nevada Test Site region, southern Nevada.-Continued

[Stratigraphic units and epochs are from the U.S. Geological Survey Geologic Names Lexicon (GEOLEX) database (http://ngmdb.usgs.gov/Geolex/geolex home.html). Age assignments are based on the time scale of Young and Laurie (1996), which McArthur and others (2001) used to construct the Paleozoic seawater curve (fig. 3). Maximum, minimum, and mean $\mathrm{Sr}$ isotopic compositions are determined from values shown in figure 3 averaged over the time period given. Age ranges are given in millions of years before present (m.y.)]

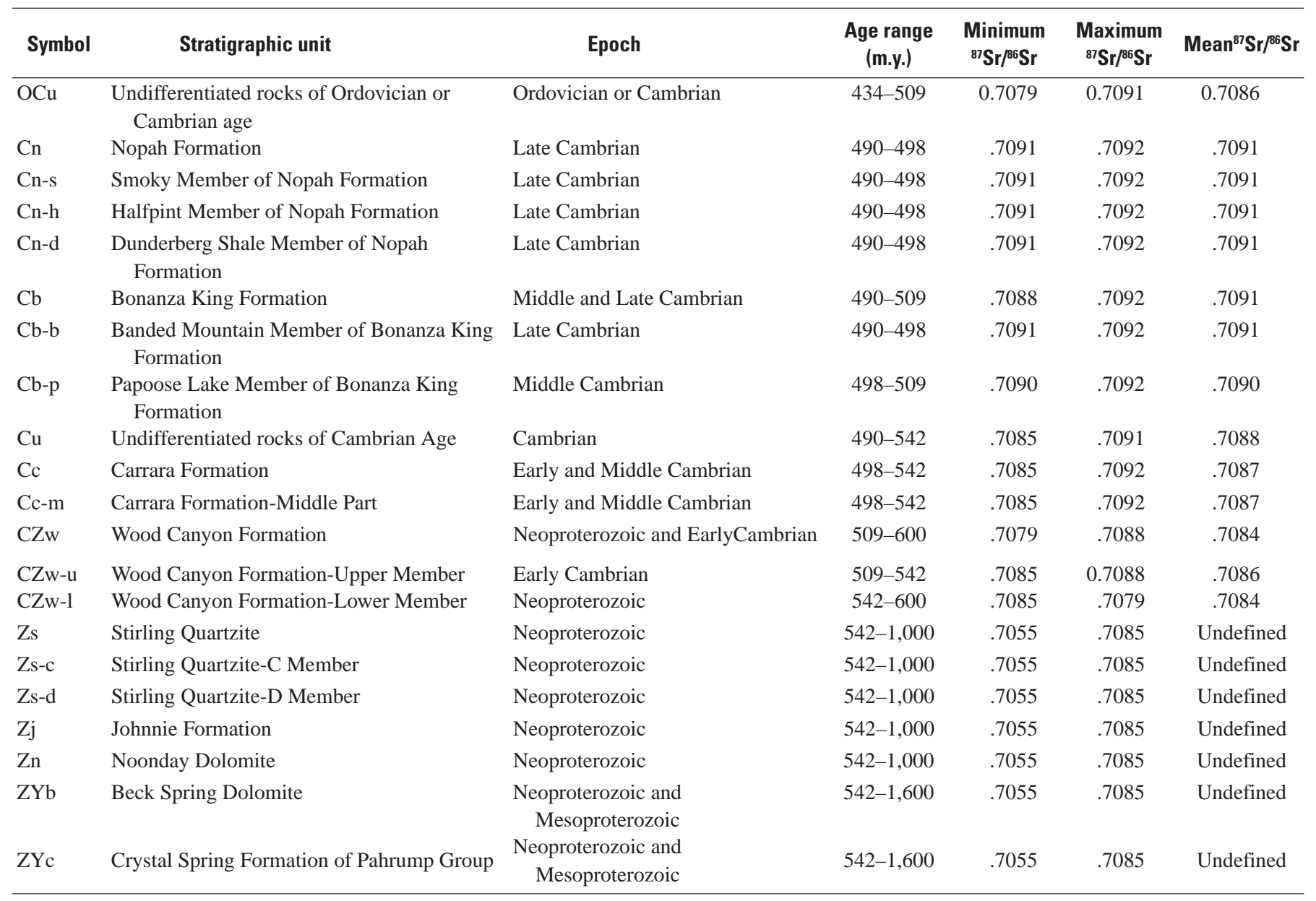

\section{Evolution of Pre-Tertiary Seawater Strontium Isotopes}

The isotopic composition of seawater has evolved through time due to the balance of fluxes from continental (fluvial inputs), mantle (volcanic and hydrothermal activity at mid-ocean spreading centers), and continental shelf (diagenesis and dolomitization of marine carbonate) sources (Peterman and others, 1970; Burke and others, 1982; Faure,
1986; Peterman and Stuckless, 1992; Veizer and others, 1999, Faure and Mensing, 2005, p. 440). Determination of the seawater ${ }^{87} \mathrm{Sr} /{ }^{86} \mathrm{Sr}$ evolution curve is possible because $\mathrm{Sr}$ concentrations in biogenic carbonate are high ( $\mathrm{Sr}$ readily substitutes for $\mathrm{Ca}$, especially in the aragonite crystal structure) whereas radioactive ${ }^{87} \mathrm{Rb}$ [the parent isotope for ${ }^{87} \mathrm{Sr}$ with a half-life of 48.8 million years (m.y.)] is excluded. Therefore, seawater $\mathrm{Sr}$ is incorporated into the crystal structure of marine calcite or aragonite and remains unchanged with time in 
rocks and carbonate fossils that have remained unmodified by secondary processes. Values of ${ }^{87} \mathrm{Sr} /{ }^{86} \mathrm{Sr}$ for Triassic through Cambrian brachiopods, belemnites, and conodonts and Neoproterozoic carbonate rocks from many locations around the world have been compiled to define the Paleozoic seawater ${ }^{87} \mathrm{Sr} /{ }^{86} \mathrm{Sr}$ evolution curve, shown in figure 3 along with bounding curves that represent probable uncertainties for mean seawater compositions at any one time period. Seawater ${ }^{87} \mathrm{Sr} /{ }^{86} \mathrm{Sr}$ values fluctuated from a high of around 0.7092 during the late Cambrian Period to a low of around 0.7070 in the late Permian Period with numerous fluctuations in between.

Post-depositional modification of ${ }^{87} \mathrm{Sr} /{ }^{86} \mathrm{Sr}$ can occur by several mechanisms including (1) accumulation of ${ }^{87} \mathrm{Sr}$ from the radioactive decay of small amounts of ${ }^{87} \mathrm{Rb}$ incorporated in the rock, especially in finely dispersed clay particles, (2) exchange of Sr with fluids during diagenesis or dolomitization, or (3) introduction of exotic strontium by hydrothermal fluids carrying radiogenic ${ }^{87} \mathrm{Sr}$ derived from basement sources (Peterman and others, 1994). These processes typically drive rock ${ }^{87} \mathrm{Sr} /{ }^{86} \mathrm{Sr}$ compositions toward higher (more radiogenic) values. Dolomites with low Sr concentrations may be particularly susceptible to subsequent introduction of exotic Sr.

\section{Purpose and Scope}

The purpose and scope of this report are to present chemical and ${ }^{87} \mathrm{Sr} /{ }^{86} \mathrm{Sr}$ data from cuttings and core samples of Paleozoic carbonate rocks from NTS boreholes (table 2) where ground-water data are available. Paleozoic rock samples from 20 boreholes in the Yucca Flat, Rainier Mesa, Frenchman Flat, and Mercury Valley were collected in 2005 and 2006 from zones within the LCA that produced water. In addition to these recently acquired data, chemical and isotopic data acquired from the same laboratory also are reported for rock samples obtained in the early and middle 1990s. These samples are from outcrops located outside the NTS and from two boreholes in the southwestern part of the NTS. These data are discussed in Peterman and others (1994), but were not published previously. Data in this report are presented in geospatial, tabular, and graphic forms, and are discussed in terms of the degree to which the compositions may have been modified by post-depositional chemical processes. However, no attempt is made to interpret these data with respect to water-rock interactions, reactive-transport mechanisms, or ground-water flow-path identification.

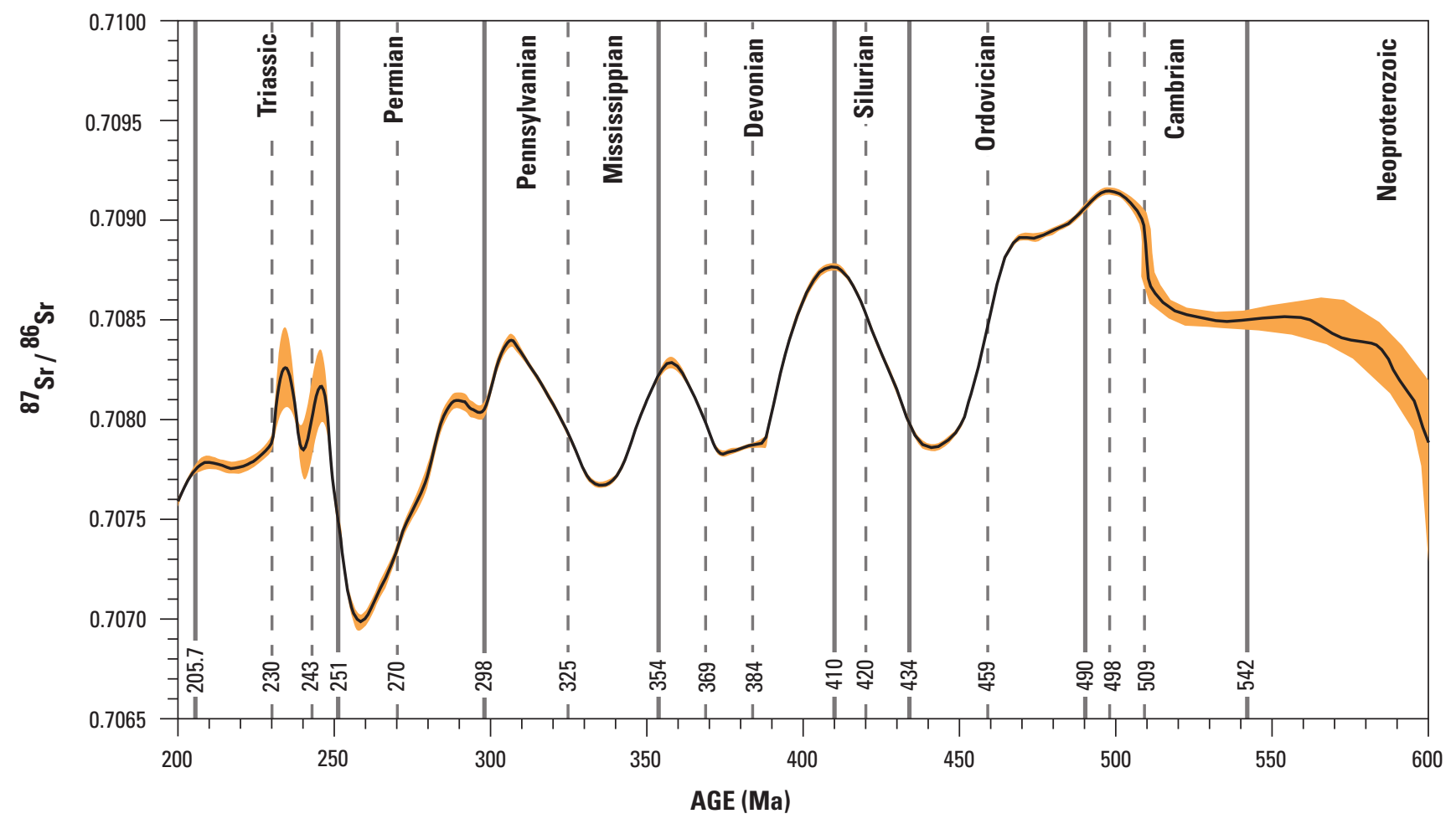

Figure 3. Variation in strontium isotopic composition $\left({ }^{87} \mathrm{Sr} /{ }^{86} \mathrm{Sr}\right)$ of seawater during part of the Phanerozoic and Neoproterozoic based on analyses of unaltered brachiopods, belemnites, and conodonts from various locations worldwide. Dark curve represents the best-fit value for ages and ${ }^{87} \mathrm{Sr} /{ }^{86} \mathrm{Sr}$ values for data regressed by McArthur and others (2001) along with the 95-percent confidence level estimates (orange-shaded area). Solid vertical lines represent Period boundaries and dashed vertical lines represent Epoch boundaries based on the timescale of Young and Laurie (1996) as given in McArthur and others (2001), table 1. 
Table 2. Locations of boreholes from which core samples were obtained at the Nevada Test Site, Nye County, Nevada.

[Location of sampling sites are shown in figure 1B. Additional information on these and other boreholes associated with the Department of Energy weapons testing program at the Nevada Test Site is available at http://nevada.usgs.gov/mercury/core.html. Abbreviations: DOE, U.S. Department of Energy; USGS, U.S Geological Survey; m, meter; UTM, Universal Transverse Mercator]

\begin{tabular}{|c|c|c|c|c|c|c|c|}
\hline $\begin{array}{c}\text { DOE borehole } \\
\text { identification No. }\end{array}$ & $\begin{array}{c}\text { Borehole } \\
\text { identification } \\
\text { No. }\end{array}$ & $\begin{array}{c}\text { USGS site } \\
\text { identification } \\
\text { No. }\end{array}$ & $\begin{array}{l}\text { UTM- } \\
\text { Easting, } \\
\text { zone } 11 \\
\text { (m) }\end{array}$ & $\begin{array}{l}\text { UTM- } \\
\text { Northing, } \\
\text { zone } 11 \\
\text { (m) }\end{array}$ & $\begin{array}{l}\text { Land } \\
\text { surface } \\
\text { elevation } \\
\text { (m) }\end{array}$ & $\begin{array}{c}\text { Date } \\
\text { constructed }\end{array}$ & $\begin{array}{c}\text { Borehole } \\
\text { depth } \\
\text { (m) }\end{array}$ \\
\hline Army \#1 Water Well & Army \#1 & 363530116021401 & 586,120 & $4,049,800$ & 961.1 & $07-15-62$ & 595.3 \\
\hline ER-3-1 & ER3-1 & 370116115561301 & 594,658 & $4,097,339$ & $1,343.2$ & 05-20-94 & 855.6 \\
\hline ER-5-3 \#2 & ER5-3 \#2 & 365223115561801 & 594,624 & $4,081,120$ & $1,016.3$ & $03-20-01$ & $1,732.2$ \\
\hline ER-6-2 & ER6-2 & 365740116043501 & 582,236 & $4,090,745$ & $1,289.7$ & 07-21-94 & $1,045.5$ \\
\hline ER-7-1 & ER7-1 & 370424115594301 & 589,315 & $4,103,275$ & $1,294.2$ & 02-09-03 & 762.0 \\
\hline ER-12-1 & ER12-1 & 371106116110401 & 572,412 & $4,115,493$ & $1,773.1$ & $11-24-92$ & $1,093.6$ \\
\hline ER-12-3 & ER12-3 & 371142116125102 & 569,748 & $4,116,592$ & $2,250.9$ & $04-28-05$ & $1,496.0$ \\
\hline ER-12-4 & ER12-4 & 371311116105902 & 572,473 & $4,119,346$ & $2,097.9$ & $06-01-05$ & $1,132.3$ \\
\hline UE-7nS & UE7nS & 370556116000901 & 588,644 & $4,106,091$ & $1,331.0$ & $07-14-76$ & 672.1 \\
\hline UE-10j & UE10j & 371108116045301 & 581,527 & $4,115,645$ & $1,394.1$ & $02-24-93$ & 796.4 \\
\hline UE-15d Water Well & UE15d & 371230116021501 & 585,061 & $4,118,301$ & $1,397.9$ & $04-17-62$ & $1,829.1$ \\
\hline UE-16d Eleana Water Well & UE16d & 370412116095101 & 574,301 & $4,102,761$ & $1,427.7$ & $03-03-81$ & 914.4 \\
\hline $\mathrm{UE}-25 \mathrm{p} \# 1$ & UE25p \#1 & 364938116252102 & 551,509 & $4,075,663$ & $1,113.9$ & $05-24-83$ & $1,805.0$ \\
\hline UE-25 a \#3 & UE25a \#3 & 365147116185301 & 561,079 & $4,079,703$ & $1,385.6$ & $10-10-78$ & 771.1 \\
\hline USGS HTH \#3 & HTH \#3 & 364830115512601 & 601,932 & $4,074,016$ & $1,062.0$ & $05-09-62$ & 566.9 \\
\hline USGS Test Well C (WW-C) & TW-C & 365508116003501 & 588,208 & $4,086,130$ & $1,194.8$ & $03-30-61$ & 518.2 \\
\hline USGS Test Well D & TW-D & 370418116044501 & 582,224 & $4,103,327$ & $1,265.1$ & $01-08-61$ & 594.4 \\
\hline
\end{tabular}

\section{Analytical Methods}

Core and cutting samples of Paleozoic rock core were obtained in 2006 from material archived at the U.S. Geological Survey (USGS) Core Library and Data Center in Mercury, Nevada. Intervals corresponding to water-producing zones were examined and samples were selected based on availability, representation of macroscopic features, and location in the stratigraphic section. Borehole intervals, sample types, stratigraphic units, and sample descriptions are given in table 3. Where only cuttings were available, samples with the largest fragment size were selected preferentially. In a few cases, special features were targeted, such as secondary calcite veins or altered breccia zones, to evaluate the differences between primary and secondary ${ }^{87} \mathrm{Sr} /{ }^{86} \mathrm{Sr}$ signatures; however, most samples were collected to evaluate unaltered, bulk-rock compositions. Stratigraphic units were assigned to samples using lithologic logs from borehole completion reports to DOE, which have been compiled recently by the U.S. Geological Survey (2006). Other sources include Maldonado and others, (1979) for borehole UE-25 a \#3, and Carr and others, (1986) for borehole UE-25 p \#1. These assignments were made by correlations with known stratigraphic sections or through biostratigraphic assignments, most commonly using conodonts (typically evaluated and reported as unpublished data by A. Harris, U.S. Geological Survey). 


\section{Strontium Isotopic Composition of Paleozoic Carbonate Rocks, Nevada Test Site Vicinity, Nevada and California}

Table 3. Description of samples analyzed for strontium isotopic compositions from boreholes at the Nevada Test Site, Nye County, Nevada.

[Stratigraphic units are from lithology logs included in borehole completion reports to U.S. Department of Energy (see U.S. Geological Survey, 2006, for compilation of data and references, as well as Maldonado and others [1979], and Carr and others [1986]). Stratigraphic unit symbols are defined in table 1. Core and cutting samples were obtained in 2006 except for samples from boreholes UE-25 a \#3 and UE-25 p \#1, which were obtained in the early 1990s. Borehole depths are measured in feet below land surface. Abbreviations: DOE, Department of Energy; m, meter; mm, millimeter; >, greater than; <, less than; \pm , plus or minus]

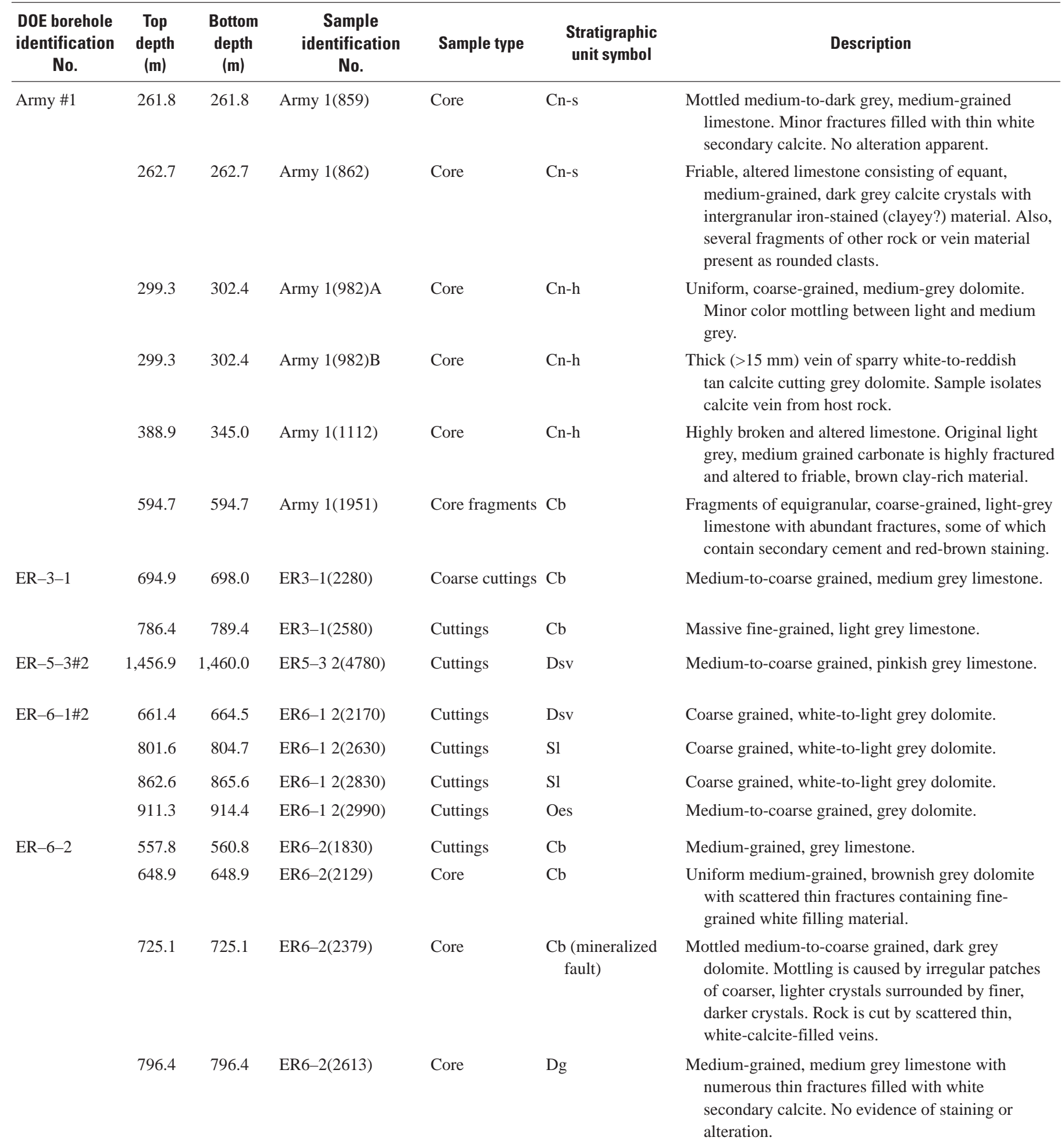


Table 3. Description of samples analyzed for strontium isotopic compositions from boreholes at the Nevada Test Site, Nye County, Nevada.-Continued

[Stratigraphic units are from lithology logs included in borehole completion reports to U.S. Department of Energy (see U.S. Geological Survey, 2006, for compilation of data and references, as well as Maldonado and others [1979], and Carr and others [1986]). Stratigraphic unit symbols are defined in table 1. Core and cutting samples were obtained in 2006 except for samples from boreholes UE-25 a \#3 and UE-25 p \#1, which were obtained in the early 1990s. Borehole depths are measured in feet below land surface. Abbreviations: DOE, Department of Energy; m, meter; mm, millimeter; >, greater than; <, less than; \pm , plus or minus]

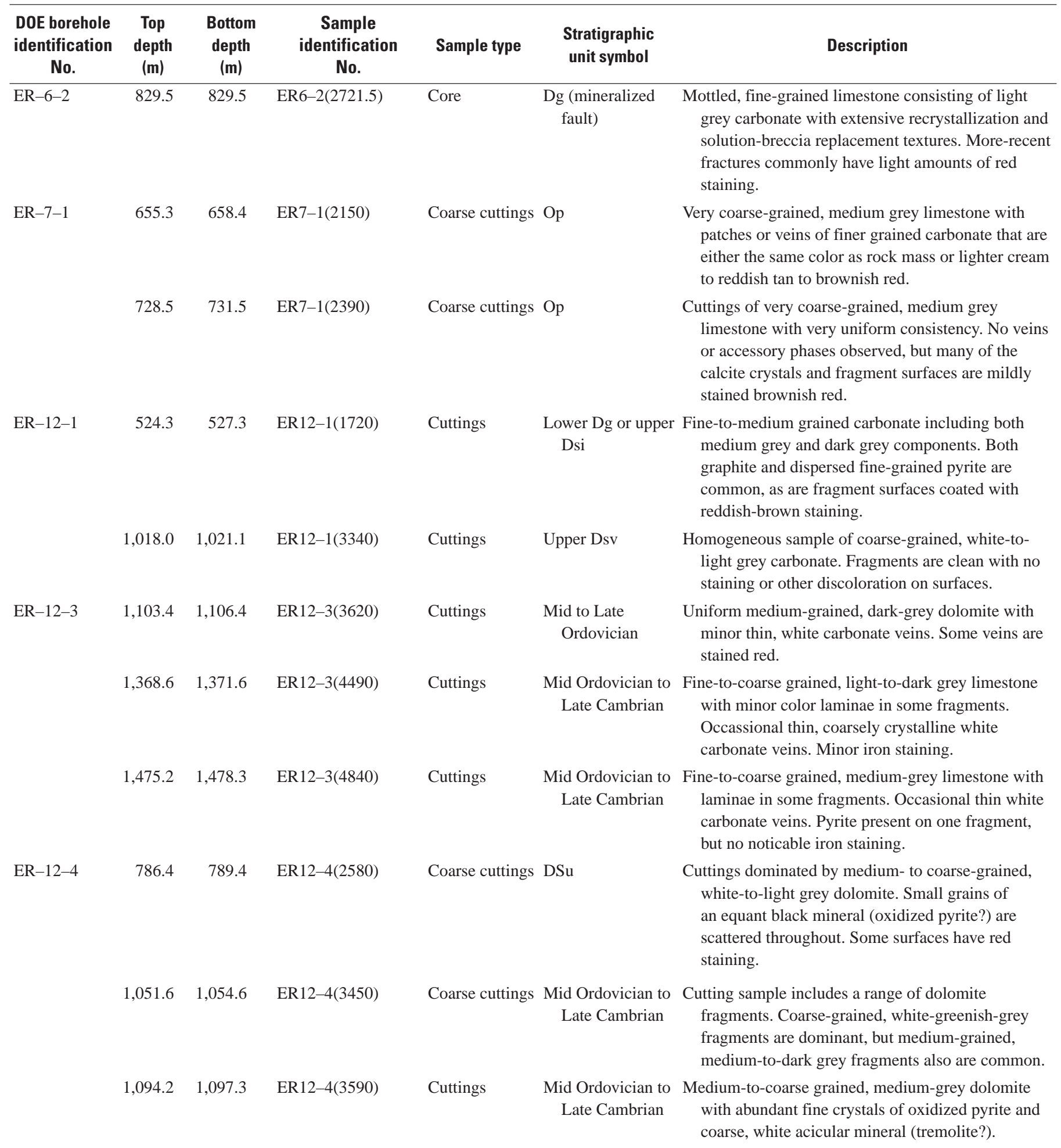


Table 3. Description of samples analyzed for strontium isotopic compositions from boreholes at the Nevada Test Site, Nye County, Nevada.-Continued

[Stratigraphic units are from lithology logs included in borehole completion reports to U.S. Department of Energy (see U.S. Geological Survey, 2006, for compilation of data and references, as well as Maldonado and others [1979], and Carr and others [1986]). Stratigraphic unit symbols are defined in table 1. Core and cutting samples were obtained in 2006 except for samples from boreholes UE-25 a \#3 and UE-25 p \#1, which were obtained in the early 1990s. Borehole depths are measured in feet below land surface. Abbreviations: DOE, Department of Energy; m, meter; mm, millimeter; >, greater than; <, less than; \pm , plus or minus]

\begin{tabular}{|c|c|c|c|c|c|c|}
\hline $\begin{array}{l}\text { DOE borehole } \\
\text { identification } \\
\text { No. }\end{array}$ & $\begin{array}{l}\text { Top } \\
\text { depth } \\
(\mathrm{m})\end{array}$ & $\begin{array}{l}\text { Bottom } \\
\text { depth } \\
(\mathrm{m})\end{array}$ & $\begin{array}{c}\text { Sample } \\
\text { identification } \\
\text { No. }\end{array}$ & Sample type & $\begin{array}{c}\text { Stratigraphic } \\
\text { unit symbol }\end{array}$ & Description \\
\hline ER-16-1 & $1,079.0$ & $1,082.0$ & ER16-1(3540) & Cuttings & $\mathrm{Dg}$ & $\begin{array}{l}\text { Cuttings are dominated by fine-grained, black } \\
\text { carbonate with graphite-like sheen on surfaces. } \\
\text { Other lithologies are present, but were excluded } \\
\text { from sample. }\end{array}$ \\
\hline HTH-3 & 563.9 & 566.9 & HTH-3(1850) & Core fragments & Op & $\begin{array}{l}\text { Fragments of equigranular, coarse-grained, medium- } \\
\text { grey dolomite with abundant fractures, some } \\
\text { of which contain micro-breccia and fine, white } \\
\text { secondary cement } \pm \text { brown staining. }\end{array}$ \\
\hline TW-C & 446.6 & 446.6 & TW-C(1463.5) & Core & $\mathrm{Dg}$ & $\begin{array}{l}\text { Coarse-grained, mottled grey limestone with } \\
\text { extensive secondary veining and recrystallization } \\
\text { that yields solution-breccia textures in areas. } \\
\text { Secondary calcite is white to brownish red. }\end{array}$ \\
\hline TW-D & 540.4 & 541.6 & TW-D(1773) & Cuttings & Cn-d & $\begin{array}{l}\text { Massive, fine-to-medium-grained, grey limestone. } \\
\text { Coarse cuttings have spotty, clay-like coating on } \\
\text { fragment surfaces. }\end{array}$ \\
\hline UE-2ce & 438.9 & 442.0 & UE2ce(1440) & Cuttings & $\mathrm{Cn}$ or $\mathrm{Cb}$ & Coarse grained, white-to-light grey dolomite. \\
\hline \multirow[t]{2}{*}{ UE-7nS } & 625.5 & 625.5 & UE7nS(2052.2) & Core & Op-av & $\begin{array}{l}\text { Mottled limestone consisting of medium-to-coarse } \\
\text { grained, light-brown limestone with irregular } \\
\text { patches of fine-grained, brownish-red alteration } \\
\text { product. }\end{array}$ \\
\hline & 667.5 & 667.5 & $\mathrm{UE7nS}(2190)$ & Core & Op-av & $\begin{array}{l}\text { Mottled coarse-grained limestone. Patches of coarse, } \\
\text { light grey limestone are separated by lenses and } \\
\text { veins of finer-grained, iron-stained material. }\end{array}$ \\
\hline UE-10j & 393.2 & 394.7 & UE10j(1290) & Coarse cuttings & $\mathrm{Cn}-\mathrm{s}$ & $\begin{array}{l}\text { Massive, fine-to-medium-grained grey dolomite. } \\
\text { Rock is highly fractured with very thin white, clay- } \\
\text { like material commonly present in fractures. }\end{array}$ \\
\hline
\end{tabular}


Table 3. Description of samples analyzed for strontium isotopic compositions from boreholes at the Nevada Test Site, Nye County, Nevada.-Continued

[Stratigraphic units are from lithology logs included in borehole completion reports to U.S. Department of Energy (see U.S. Geological Survey, 2006, for compilation of data and references, as well as Maldonado and others [1979], and Carr and others [1986]). Stratigraphic unit symbols are defined in table 1. Core and cutting samples were obtained in 2006 except for samples from boreholes UE-25 a \#3 and UE-25 p \#1, which were obtained in the early 1990s. Borehole depths are measured in feet below land surface. Abbreviations: DOE, Department of Energy; m, meter; mm, millimeter; >, greater than; <, less than]

\begin{tabular}{|c|c|c|c|c|c|c|}
\hline $\begin{array}{l}\text { DOE borehole } \\
\text { identification } \\
\text { No. }\end{array}$ & $\begin{array}{l}\text { Top } \\
\text { depth } \\
(\mathrm{m})\end{array}$ & $\begin{array}{l}\text { Bottom } \\
\text { depth } \\
(\mathrm{m})\end{array}$ & $\begin{array}{l}\text { Sample } \\
\text { identification } \\
\text { No. }\end{array}$ & Sample type & $\begin{array}{l}\text { Stratigraphic } \\
\text { unit symbol }\end{array}$ & Description \\
\hline UE-10j & 656.5 & 656.5 & UE10j(2154) & Core & $\mathrm{Cb}-\mathrm{b}$ & $\begin{array}{l}\text { Massive coarse-grained, white-to-light grey dolomite. } \\
\text { Minor fractures contain light brown staining. }\end{array}$ \\
\hline $\mathrm{UE}-15 \mathrm{~d}$ & $1,827.0$ & $1,827.0$ & UE15d(5994) & Core & $\mathrm{Zj}$ or $\mathrm{Zn}$ & $\begin{array}{l}\text { Fine-grained, medium-grey dolomite with light- } \\
\text { colored spots of coarser carbonate. Scattered } \\
\text { fractures are filled with white secondary carbonate. }\end{array}$ \\
\hline \multirow[t]{2}{*}{ UE-16d } & 311.0 & 313.9 & UE16d(1020) & Cuttings & PPt & Massive, fine-to-medium-grained, grey limestone. \\
\hline & 472.4 & 475.5 & UE16d(1550) & Cuttings & MDe & $\begin{array}{l}\text { Very coarse, white-to-light grey limestone } \\
\text { concentrated from heterogeneous lithologies } \\
\text { (including volcanic and fine-grained carbonates) in } \\
\text { cuttings sample by extensive hand picking. }\end{array}$ \\
\hline \multirow{8}{*}{ UE-25 a \#3 } & 435.9 & 436.0 & UE25a3-1430 & Core & Mc or MDg & Light tannish-grey, thermally altered shale/argillite. \\
\hline & 525.0 & 525.1 & UE25a3-1722 & Core & Mc or MDg & Light grey, thermally altered shale/argillite. \\
\hline & 562.5 & 562.6 & UE25a3-1846 & Core & Mc or MDg & Light grey, thermally altered shale/argillite. \\
\hline & 637.8 & 637.9 & UE25a3-2093 & Core & Mc or MDg & Light grey, coarse-grained metasandstone. \\
\hline & 697.2 & 697.3 & UE25a3-2287 & Core & Mc or MDg & Light greenish-grey, calcareous argillite. \\
\hline & 741.1 & 741.2 & UE25a3-2432 & Core & $\mathrm{Du}$ & Dark orange-yellow, ferruginous clay seam. \\
\hline & 759.6 & 759.7 & UE25a3-2492 & Core & $\mathrm{Du}$ & White calcitic marble. \\
\hline & 766.4 & 766.5 & UE25a3-2514 & Core & $\mathrm{Du}$ & Light grey, laminated marble. \\
\hline \multirow[t]{3}{*}{ UE-25 p \#1 } & $1,277.9$ & $1,278.0$ & HD-622 & Core & DSIm & Light grey, massive, pelloidal dolomite. \\
\hline & $1,284.1$ & $1,284.2$ & HD-621 & Core & DSIm & Light grey, fine-grained, massive dolomite. \\
\hline & $1,798.3$ & $1,798.4$ & UE25p 1-5900 & Core & $\mathrm{Sr}$ & Dark grey, fine-grained dolomite with thin lamellae. \\
\hline
\end{tabular}


Samples from road cuts or outcrops were collected between 1989 and 1994 as part of a study to evaluate the usefulness of strontium isotopes as indicators of epithermal mineralization in areas surrounding Yucca Mountain, Nevada, the potential site for a geologic repository for high-level radioactive waste (Peterman and others, 1994). Samples of mineralized and unmineralized Paleozoic carbonate rocks were analyzed to represent geologic map units in several areas to the west, south, and east of the NTS (table 4; fig. 1). In addition, core samples from Paleozoic strata underlying the Tertiary volcanic rocks constituting Yucca Mountain (borehole UE-25 p \#1) were included.

Samples of NTS core were split and representative fragments were selected for further processing. Samples of cuttings were examined under a binocular microscope and fragments of foreign material likely representing down-hole contamination by rock fragments from overlying lithologic units were removed. Final samples of cuttings and core fragments weighed between 3 and 50 grams (g). Outcrop samples were trimmed as much as possible in the field to remove weathering rinds or coatings of pedogenic carbonate and were subsampled further in the laboratory using a small diamond core drill (1.3-centimeter outside diameter). Resulting unweathered core samples ranged from 10 to $20 \mathrm{~g}$. All samples were crushed and then pulverized to less than 0.075 millimeters using a steel shatterbox. All rock preparation and analyses were done by USGS Yucca Mountain Project Branch personnel in Denver, Colorado, between 1990 and 2006.

Analyses of the recently acquired NTS borehole samples were made on partial digestions (leachates) obtained by adding approximately 20 milliliters of 0.2 molar nitric acid to $0.1 \mathrm{~g}$ of rock powder. Acid solutions were allowed to react with rock powders in a $50^{\circ} \mathrm{C}$ incubator oven for 12 to 24 hours. Acid volumes were sufficient to maintain low $\mathrm{pH}$ in the final leachate solutions. Leachates then were analyzed for a selected suite of major and trace constituents $\left(\mathrm{MgO}, \mathrm{CaO}, \mathrm{SiO}_{2}, \mathrm{Al}_{2} \mathrm{O}_{3}\right.$, $\mathrm{MnO}, \mathrm{Rb}, \mathrm{Sr}$, $\mathrm{Th}$, and $\mathrm{U}$ ) by inductively coupled plasma mass spectrometry (ICP-MS). Strontium was purified from the same leachates using Eichrom Sr-SPEC ${ }^{\mathrm{TM}}$ resin and ${ }^{87} \mathrm{Sr} /{ }^{86} \mathrm{Sr}$ isotopic compositions were measured using a Finnigan MAT $262^{\mathrm{TM}}$ multiple-collector thermal-ionization mass spectrometer operating in static mode. The instrument was calibrated using the USGS rock standard EN-1 (calcite from a modern Tridacna shell from Enewetok Lagoon in the western Pacific Ocean; Ludwig and others, 1988). To correct for instrument drift and eliminate small interlaboratory biases (Faure and Mensing, 2005, p. 78), measured ${ }^{87} \mathrm{Sr} /{ }^{86} \mathrm{Sr}$ values for samples in each magazine were normalized to the value obtained from the EN-1 standard measured in the same magazine and adjusted to an assigned value of 0.70920 for modern mean ocean water (Elderfield, 1986, p. 77). Replicate ${ }^{87} \mathrm{Sr} /{ }^{86} \mathrm{Sr}$ analyses of the uncorrected EN-1 standard varied by less than \pm 0.00005 ( 0.007 percent) at the 95 -percent confidence level (2-sigma). Results for the National Institute of Standards and Technology strontium carbonate standard, SRM 987, (accepted ${ }^{87} \mathrm{Sr} /{ }^{86} \mathrm{Sr}$ value of 0.71025 ; Faure and Mensing, 2005, p. 79) analyzed between 1997 and 2006 yielded a weighted average ${ }^{87} \mathrm{Sr} /{ }^{86} \mathrm{Sr}$ value of $0.710270 \pm 0.000011$ (95percent confidence limit) indicating that estimates of accuracy and precision are similar. Sr contributions from the chemical procedure (blank) were approximately $2 \times 10^{-9} \mathrm{~g}$, which are 5-7 orders of magnitude lower than the total amount of $\mathrm{Sr}$ contributed from the samples.

Rock powders from outcrop samples were analyzed before ICP-MS capabilities became available. Instead, selected elements ( $\mathrm{Rb}, \mathrm{Sr}, \mathrm{Y}, \mathrm{Zr}, \mathrm{Nb}, \mathrm{Ba}, \mathrm{La}$, and $\mathrm{Ce}$ ) were analyzed by energy-dispersive XRF (X-ray fluorescence) spectroscopy on bulk rock powders. Results for the rock-forming constituents $\mathrm{MgO}$ and $\mathrm{CaO}$ are not available. ${ }^{87} \mathrm{Sr} /{ }^{86} \mathrm{Sr}$ was analyzed in the carbonate fraction by dissolving subgram powdered aliquots in 1 molar hydrochloric acid followed by purification of Sr using cation exchange resins. ${ }^{87} \mathrm{Sr} /{ }^{86} \mathrm{Sr}$ values were measured using either the instrument described in the previous paragraph, or on one of two single collector instruments (National Bureau of Standards instrument or VG Isomass 54E) operating in peakhopping mode. The measurements were treated identically to those described above using results of EN-1 to normalize unknown ${ }^{87} \mathrm{Sr} /{ }^{86} \mathrm{Sr}$ values. Samples of drill core obtained in the early 1990's from UE-25 p \#1 (fig. 1B) were processed in the same manner as outcrop samples. Samples of Gap Wash Formation siliciclastic rocks (Eleana Formation equivalent; Trexler and others, 2003) from UE-25 a \#3 (fig. 1B) as well as two of the outcrop samples (HD-1107 and HD-1114 with respective Map No. 4 and 5 in table 4) were digested using hydrofluoric and sulfuric acids prior to $\mathrm{Sr}$ purification.

To emphasize small but significant variations in ${ }^{87} \mathrm{Sr} /{ }^{86} \mathrm{Sr}$, data also are reported as per mil (\%o) deviations from modern seawater $\left({ }^{87} \mathrm{Sr} /{ }^{86} \mathrm{Sr}=0.70920\right)$ using the equation

$$
\delta^{87} \mathrm{Sr}=\left(\frac{{ }^{87} \mathrm{Sr} /{ }^{86} \mathrm{Sr}_{\text {unknown }}}{0.70920}-1\right) \times 1,000 .
$$

Analytical uncertainties in $\delta^{87} \mathrm{Sr}$ values are typically less than \pm 0.07 per mil at the 95 -percent confidence level. Although modern seawater provides a useful reference point for comparative purposes, it is desirable to know whether present-day ${ }^{87} \mathrm{Sr} /{ }^{86} \mathrm{Sr}$ compositions of the marine carbonate rocks have been modified from seawater ${ }^{87} \mathrm{Sr} /{ }^{86} \mathrm{Sr}$ compositions that were present at the time of deposition. Therefore, $\delta^{87} \mathrm{Sr}_{t}$ values are computed using stratigraphic age assignments and paleoseawater ${ }^{87} \mathrm{Sr} /{ }^{86} \mathrm{Sr}$ compositions using the equation,

$$
\delta^{87} \mathrm{Sr}_{\mathrm{t}}=\left(\frac{{ }^{87} \mathrm{Sr} /{ }^{86} \mathrm{Sr}_{\text {unknown }}}{{ }^{87} \mathrm{Sr} /{ }^{86} \mathrm{Sr}_{\text {paleoseawater }}}-1\right) \times 1,000,
$$

where ${ }^{87} \mathrm{Sr} /{ }^{86} \mathrm{Sr}_{\text {paleoseawater }}$ is derived from figure 3 and the stratigraphic ages listed in table 1. Explicit uncertainties for $\delta^{87} \mathrm{Sr}_{\mathrm{t}}$ are not given in this report because of the difficulty in defining uncertainties to the age assignments. However, they are expected to be as much as an order of magnitude larger than those for $\delta^{87} \mathrm{Sr}$. 
Table 4. Locations, stratigraphic unit designations, and descriptions of outcrop samples analyzed for strontium isotopic compositions from the Nevada Test Site vicinity, Clark, Lincoln, and Nye Counties, Nevada, and Inyo County, California.

[Map numbers are used to locate sites in figure 1. Stratigraphic units are from geologic maps listed in the text. Stratigraphic unit symbols are defined in table 1. Abbreviations: cm, centimeter; m, meter; UTM, Universal Transverse Mercator]

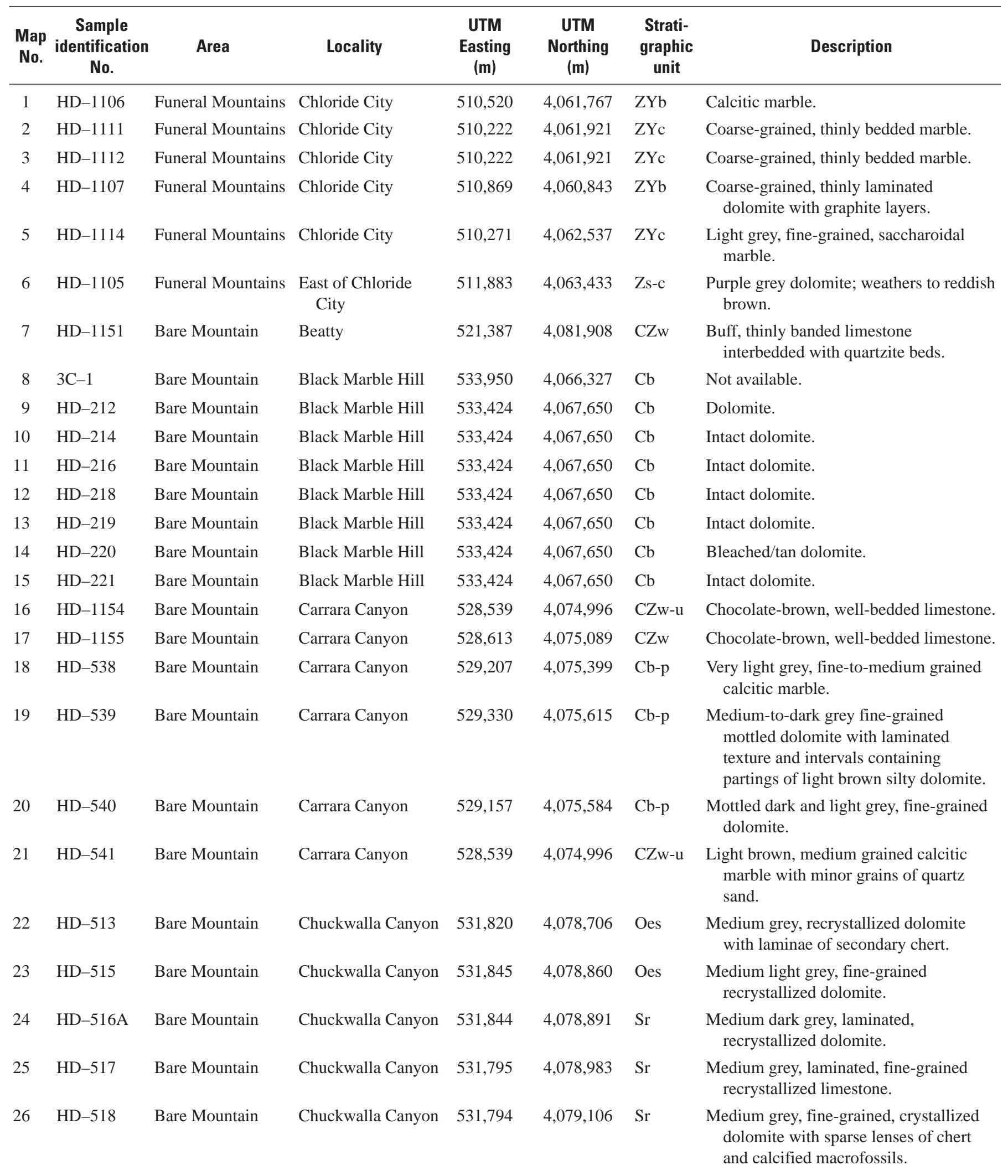


Table 4. Locations, stratigraphic unit designations, and descriptions of outcrop samples analyzed for strontium isotopic compositions from the Nevada Test Site vicinity, Clark, Lincoln, and Nye Counties, Nevada, and Inyo County, California.-Continued

[Map numbers are used to locate sites in figure 1. Stratigraphic units are from geologic maps listed in the text. Stratigraphic unit symbols are defined in table 1. Abbreviations: cm, centimeter; m, meter; UTM, Universal Transverse Mercator]

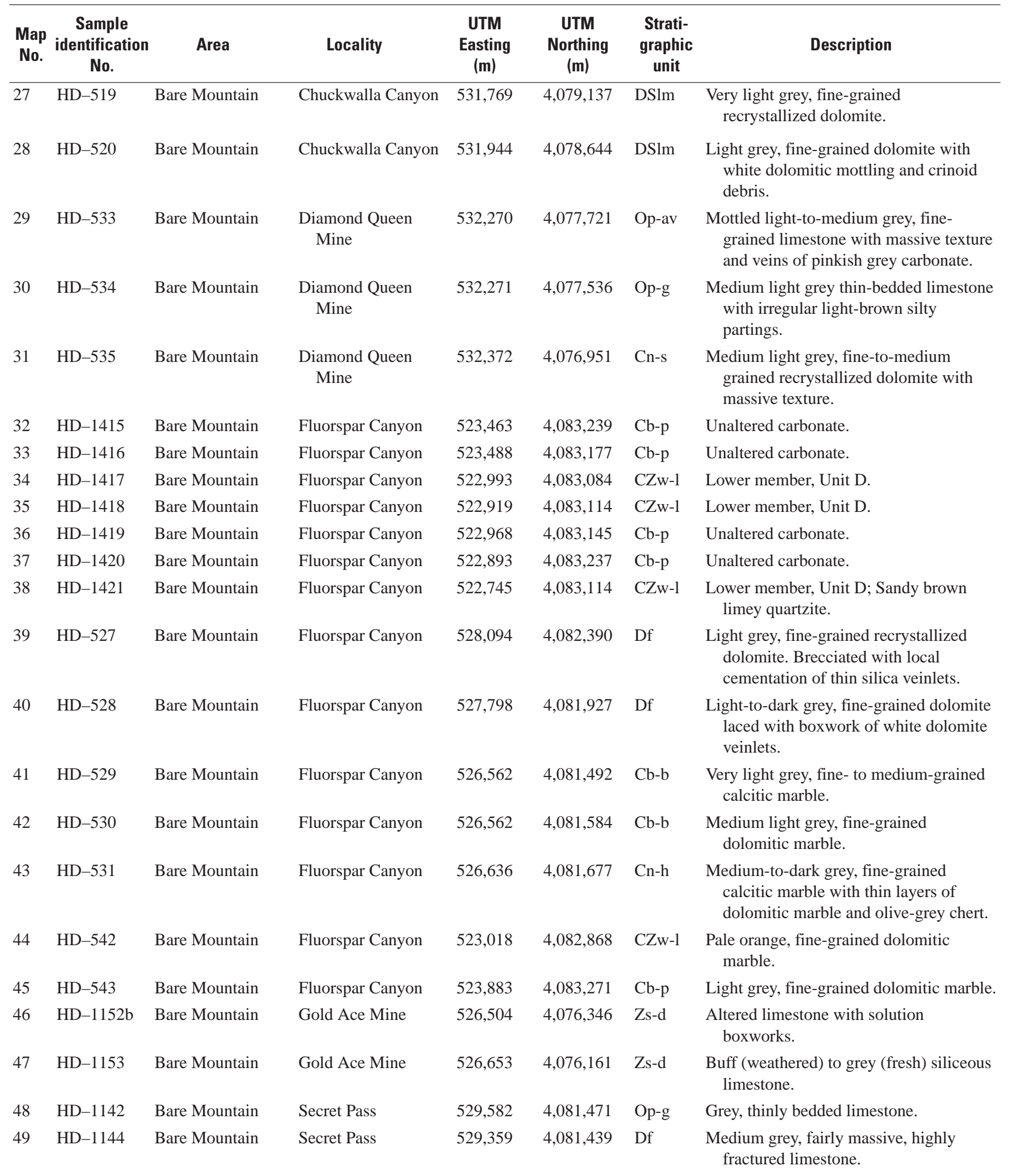


Table 4. Locations, stratigraphic unit designations, and descriptions of outcrop samples analyzed for strontium isotopic compositions from the Nevada Test Site vicinity, Clark, Lincoln, and Nye Counties, Nevada, and Inyo County, California.-Continued

[Map numbers are used to locate sites in figure 1. Stratigraphic units are from geologic maps listed in the text. Stratigraphic unit symbols are defined in table 1. Abbreviations: cm, centimeter; m, meter; UTM, Universal Transverse Mercator]

\begin{tabular}{|c|c|c|c|c|c|c|c|}
\hline $\begin{array}{l}\text { Map } \\
\text { No. }\end{array}$ & $\begin{array}{l}\text { Sample } \\
\text { identification } \\
\text { No. }\end{array}$ & Area & Locality & $\begin{array}{l}\text { UTM } \\
\text { Easting } \\
\text { (m) }\end{array}$ & $\begin{array}{l}\text { UTM } \\
\text { Northing } \\
\text { (m) }\end{array}$ & $\begin{array}{l}\text { Strati- } \\
\text { graphic } \\
\text { unit }\end{array}$ & Description \\
\hline 51 & HD-1401 & Bare Mountain & Sterling Mine & 532,006 & $4,075,440$ & $\mathrm{Cb}-\mathrm{b}$ & Unaltered carbonate. \\
\hline 52 & HD-1402 & Bare Mountain & Sterling Mine & 532,006 & $4,075,440$ & $\mathrm{Cb}-\mathrm{b}$ & Unaltered carbonate. \\
\hline 54 & HD-537 & Bare Mountain & Steves Pass & 533,101 & $4,067,802$ & Zs-d & $\begin{array}{l}\text { Light brown, fine-to-medium grained } \\
\text { recyrstallized dolomite. }\end{array}$ \\
\hline 55 & HD-1146 & Bare Mountain & Tarantula Canyon & 531,147 & $4,080,121$ & MDe & $\begin{array}{l}\text { Thin-bedded limestone consisting of } \\
\text { rusty brown layers that are more } \\
\text { resistant to weathering than medium } \\
\text { grey limestone. }\end{array}$ \\
\hline 57 & HD-1147b & Bare Mountain & Tarantula Canyon & 532,039 & $4,079,908$ & Dtc & $\begin{array}{l}\text { Massive medium grey limestone with } \\
\text { reddened zones, especially along } \\
\text { fractures and bedding planes. }\end{array}$ \\
\hline 58 & HD-522 & Bare Mountain & Tarantula Canyon & 532,806 & $4,080,034$ & Dtc & Very light-grey, fine-grained dolomite. \\
\hline 59 & HD-523 & Bare Mountain & Tarantula Canyon & 532,681 & $4,080,188$ & Dtc & $\begin{array}{l}\text { Medium-to-dark grey, fine-grained } \\
\text { limestone with sparse chert nodules } \\
\text { and minor calcite veins. }\end{array}$ \\
\hline 60 & HD-526 & Bare Mountain & Tarantula Canyon & 530,106 & $4,080,425$ & Cc-m & $\begin{array}{l}\text { Medium grey, fine-grained limestone } \\
\text { mottled with light-olive-grey silty } \\
\text { dolomite and cut by thin crystalline } \\
\text { calcite veins. }\end{array}$ \\
\hline 64 & HD-1150b & Bare Mountain & Tungsten Canyon & 530,850 & $4,073,217$ & $\mathrm{CZw}$ & Orange-weathering carbonate. \\
\hline 65 & HD-546 & Striped Hills & Outlier on west side & 556,896 & $4,057,913$ & Dn & $\begin{array}{l}\text { Light-to-medium grey, fine-grained } \\
\text { massive dolomite with mottling } \\
\text { and brecciation. Light red ion oxide } \\
\text { coatings on fracture surfaces. }\end{array}$ \\
\hline 66 & HD-548 & Striped Hills & West side & 559,200 & $4,058,576$ & Op-av & $\begin{array}{l}\text { Medium- to dark-grey, rusty-weathering, } \\
\text { silty limestone. }\end{array}$ \\
\hline 67 & HD-549 & Striped Hills & West side & 559,152 & $4,058,390$ & Op-g & $\begin{array}{l}\text { Medium- to dark-grey limestone } \\
\text { containing thin rusty-weathered lenses } \\
\text { and fractures. }\end{array}$ \\
\hline 68 & HD-550 & Striped Hills & West side & 559,177 & $4,058,298$ & Op-g & $\begin{array}{l}\text { Medium- to dark-grey, very fine-grained } \\
\text { limestone containing tan to pinkish } \\
\text { grey silty laminae. }\end{array}$ \\
\hline
\end{tabular}


Table 4. Locations, stratigraphic unit designations, and descriptions of outcrop samples analyzed for strontium isotopic compositions from the Nevada Test Site vicinity, Clark, Lincoln, and Nye Counties, Nevada, and Inyo County, California.-Continued

[Map numbers are used to locate sites in figure 1. Stratigraphic units are from geologic maps listed in the text. Stratigraphic unit symbols are defined in table 1. Abbreviations: cm, centimeter; m, meter; UTM, Universal Transverse Mercator]

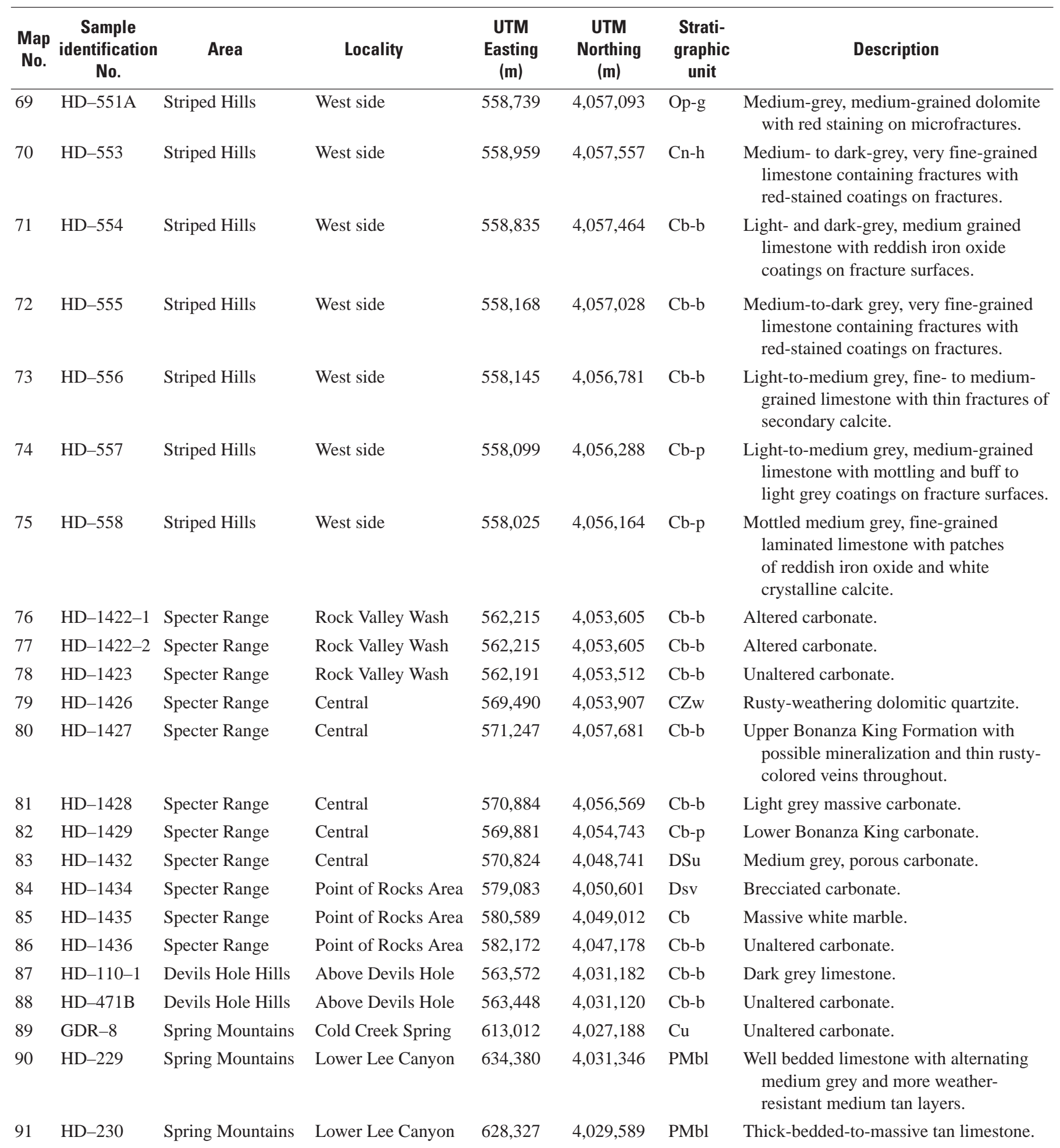


Table 4. Locations, stratigraphic unit designations, and descriptions of outcrop samples analyzed for strontium isotopic compositions from the Nevada Test Site vicinity, Clark, Lincoln, and Nye Counties, Nevada, and Inyo County, California.-Continued

[Map numbers are used to locate sites in figure 1. Stratigraphic units are from geologic maps listed in the text. Stratigraphic unit symbols are defined in table 1. Abbreviations: cm, centimeter; m, meter; UTM, Universal Transverse Mercator]

\begin{tabular}{|c|c|c|c|c|c|c|c|}
\hline $\begin{array}{l}\text { Map } \\
\text { No. }\end{array}$ & $\begin{array}{c}\text { Sample } \\
\text { identification } \\
\text { No. }\end{array}$ & Area & Locality & $\begin{array}{c}\text { UTM } \\
\text { Easting } \\
\text { (m) }\end{array}$ & $\begin{array}{c}\text { UTM } \\
\text { Northing } \\
\text { (m) }\end{array}$ & $\begin{array}{l}\text { Strati- } \\
\text { graphic } \\
\text { unit }\end{array}$ & Description \\
\hline 93 & HD-232 & Spring Mountains & Upper Lee Canyon & 620,905 & $4,022,271$ & $\mathrm{Cb}-\mathrm{b}$ & $\begin{array}{l}\text { Highly fractured, medium grey limestone } \\
\text { with some silty layers. }\end{array}$ \\
\hline 94 & HD-233 & Spring Mountains & Upper Lee Canyon & 619,928 & $4,020,839$ & $\mathrm{Cb}-\mathrm{b}$ & $\begin{array}{l}\text { White -to-light buff, coarse-grained } \\
\text { limestone. }\end{array}$ \\
\hline 95 & HD-235 & Spring Mountains & Upper Lee Canyon & 618,762 & $4,018,574$ & $\mathrm{Cn}$ & $\begin{array}{l}\text { White-to-light buff, coarse-grained, thinly } \\
\text { laminated limestone. }\end{array}$ \\
\hline 96 & HD-236 & Spring Mountains & Upper Lee Canyon & 622,300 & $4,022,414$ & Op & $\begin{array}{l}\text { Medium grey, poorly bedded limestone } \\
\text { with high degree of fracturing. }\end{array}$ \\
\hline 97 & HD-238 & Spring Mountains & Kyle Canyon & 637,123 & $4,015,392$ & $\mathrm{PMb}$ & $\begin{array}{l}\text { Light grey, thick bedded-to-massive } \\
\text { limestone that weathers to light buff. }\end{array}$ \\
\hline 99 & HD-999 & Sheep Range & Black Hills & 646,898 & $4,048,163$ & $\mathrm{Cn}-\mathrm{s}$ & Black, fine-grained laminated dolomite. \\
\hline 100 & HD-995 & Pintwater Range & Southern end & 625,873 & $4,049,217$ & Oes & $\begin{array}{l}\text { Dark-black, fine-grained dolomite with } \\
\text { local cherty layers. }\end{array}$ \\
\hline 101 & HD-996 & Pintwater Range & Southern end & 626,955 & $4,051,698$ & Op-av & $\begin{array}{l}\text { Dolomitized limestone with layers of } \\
\text { nodular chert. }\end{array}$ \\
\hline 102 & HD-997 & Pintwater Range & Southern end & 628,655 & $4,054,344$ & Oes & $\begin{array}{l}\text { Black, fine-grained laminated dolomite, } \\
\text { locally brecciated. }\end{array}$ \\
\hline 103 & HD-998 & Pintwater Range & Southern end & 627,652 & $4,054,945$ & Op-av & $\begin{array}{l}\text { Medium grey limestone with abundant } \\
\text { bioturbation and macrofossils. }\end{array}$ \\
\hline 104 & HD-1001 & Pintwater Range & Northeast side & 631,216 & $4,089,675$ & Op-av & Brownish, locally dolomitized limestone \\
\hline 109 & HD-993 & Spotted Range & Eastern side & 610,588 & $4,058,715$ & Dsi & Grey, medium-grained dolomite. \\
\hline 110 & HD-994 & Spotted Range & Central & 607,444 & $4,061,911$ & $\mathrm{Mj}$ & $\begin{array}{l}\text { Black, coarse-grained limestone with } \\
\text { abundant crinoid debris. }\end{array}$ \\
\hline 111 & HD-1004 & Spotted Range & Northeast side & 618,367 & $4,070,685$ & Op-av & $\begin{array}{l}\text { Grey limestone with local silty } \\
\text { laminations. }\end{array}$ \\
\hline 112 & HD-1003 & Spotted Range & Northeast side & 620,405 & $4,075,645$ & $\mathrm{Dg}$ & $\begin{array}{l}\text { Dark grey, fine-grained, massive } \\
\text { limestone. }\end{array}$ \\
\hline 113 & HD-1007 & Yucca Flat & $\begin{array}{l}\text { North end Eleana } \\
\text { Range }\end{array}$ & 574,337 & $4,115,797$ & Op-g & $\begin{array}{l}\text { Medium grey, fossiliferous, thin-bedded } \\
\text { limestone. }\end{array}$ \\
\hline 114 & HD-1008 & Yucca Flat & $\begin{array}{l}\text { North end Eleana } \\
\text { Range }\end{array}$ & 572,367 & $4,115,472$ & Dsv & $\begin{array}{l}\text { Dark grey, medium-grained, thick-bedded } \\
\text { dolomite. }\end{array}$ \\
\hline
\end{tabular}




\section{Major and Trace Element Chemistry}

Most of the borehole samples (34 of 48) were readily soluble losing 90.9 to 100 percent of their original sample weight during the 0.2 molar nitric acid treatment (table 5). The remaining 14 samples lost between 4.1 and 86.8 percent of the original sample weight. The greater amounts of residue in these samples are assumed to consist mostly of silicate material. Most samples were readily identifiable as limestone or dolomite, based on their $\mathrm{CaO}$ and $\mathrm{MgO}$ contents (diamonds on fig. 4). Assuming that all of the dissolved $\mathrm{CaO}$ and $\mathrm{MgO}$ is derived from the carbonate fraction, calcite $\left(\mathrm{CaCO}_{3}\right)$ mole percentages vary from 93.2 to 99.6 percent in limestone samples and 48.0 to 53.6 percent in most dolomite samples. A small number of samples have intermediate $\mathrm{MgO}$ contents, resulting in calcite mole percentages between 55.6 and 74.2 percent. These values exceed the amount of calcite that can substitute into the dolomite crystal structure (Gaines and others, 1997, p. 450). The resulting linear trend between calcite and dolomite stoichiometric end members indicates that these samples represent mixtures of the two phases. Samples with intermediate compositions include core, cuttings, and a discrete sample of sparry vein carbonate [Army\#1(982) B]. This observation indicates that excess $\mathrm{CaCO}_{3}$ contents are intrinsic to some dolomite samples and are not the result of down-hole mixing of cutting fragments.

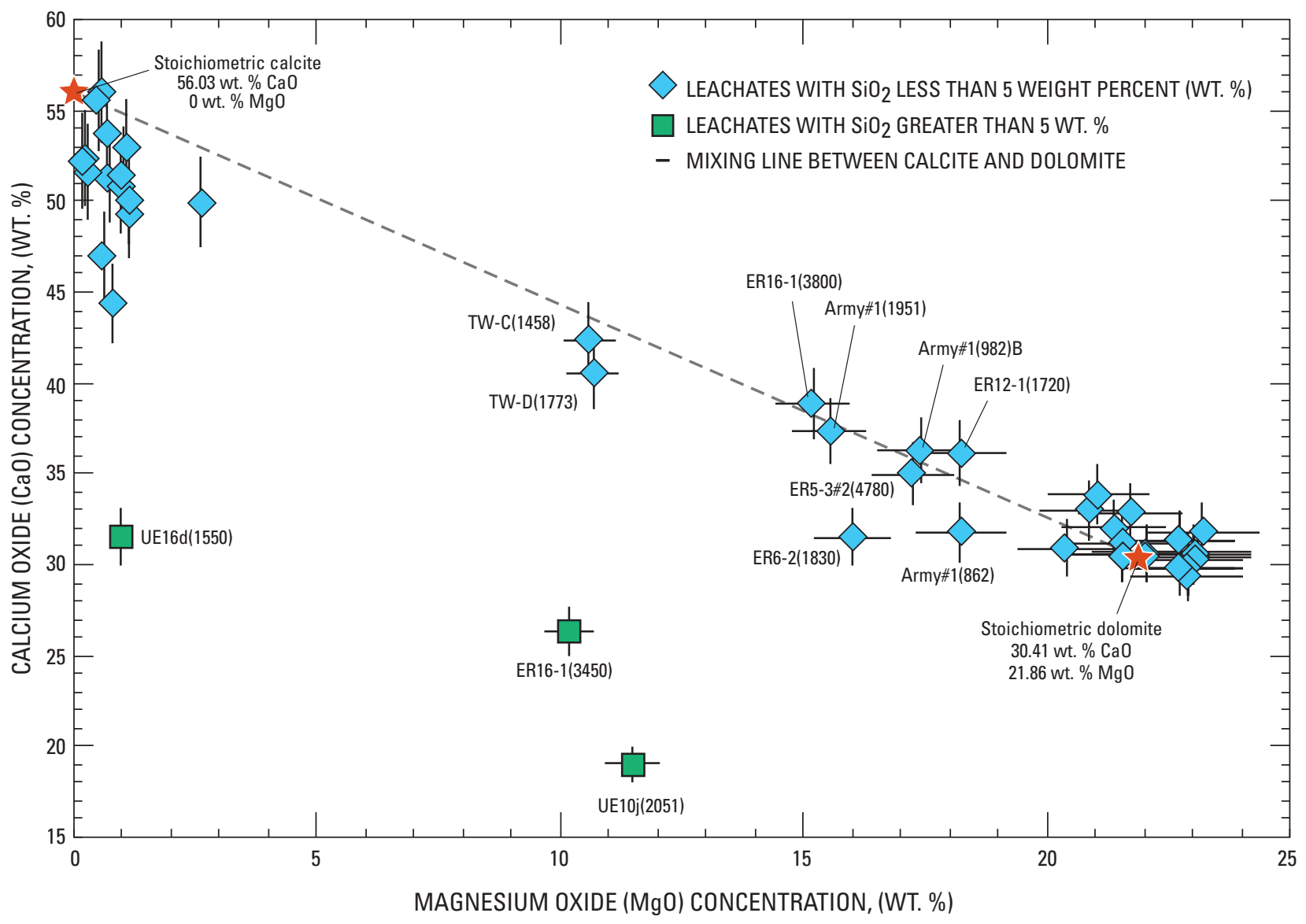

Figure 4. Relation between magnesium oxide $(\mathrm{MgO})$ and calcium oxide $(\mathrm{CaO})$ concentrations in acid leachates of borehole samples, Nevada Test Site, Nye County, Nevada. Sample descriptions and data are from tables 3 and $\underline{5}$. Error bars represent 2-sigma analytical uncertainty and are shown as 5 percent of the reported concentration value. 
Table 5. Oxide and elemental concentrations and strontium isotopic compositions $\left({ }^{87} \mathrm{Sr} /{ }^{86} \mathrm{Sr}\right)$ of nitric-acid leachates of core samples from boreholes at the Nevada Test Site, Nye County, Nevada.

[Results are for samples collected and analyzed in 2006. Oxide concentrations are given in weight percentages, and elemental concentrations are given in micrograms per gram. The less than $(<)$ symbol is used to indicate concentrations that are below minimum reporting limits and incorporate the measured dilution factors for each sample; the greater than (>) symbol is used to indicate concentrations that are above the range of standards used to define the calibration curve. Uncertainties for strontium isotopic compositions $\left({ }^{87} \mathrm{Sr} /{ }^{86} \mathrm{Sr}\right)$ are dominated by external errors for replicate analyses of the $\mathrm{Sr}$ isotope standard EN-1, therefore, a blanket ${ }^{87} \mathrm{Sr} /{ }^{86} \mathrm{Sr}$ uncertainty of 0.00005 is reported. Strontium isotopic compositions also are given in delta notation $\left(\delta^{87} \mathrm{Sr}=\left[{ }^{87} \mathrm{Sr} /{ }^{86} \mathrm{Sr} r_{\text {sample }}{ }^{187} \mathrm{Sr} /{ }^{86} \mathrm{Sr}\right.\right.$ msw $\left.)-1\right]$ $\times 1,000$ and $\delta^{87} \mathrm{Sr}_{\mathrm{t}}=\left[\left({ }^{87} \mathrm{Sr}{ }^{86} \mathrm{Sr}_{\text {sample }}{ }^{87} \mathrm{Sr}^{86}{ }^{86} \mathrm{Sr}_{\mathrm{psw}}\right)-1\right] \times 1,000$, where ${ }^{87} \mathrm{Sr}^{86}{ }^{86} \mathrm{Sr}_{\mathrm{msw}}$ is the value for modern seawater and ${ }^{87} \mathrm{Sr}^{86} \mathrm{Sr}_{\mathrm{psw}}$ is the value for paleoseawater at the time of deposition). Abbreviations: $\mathrm{MgO}$, magnesium oxide; $\mathrm{CaO}$, calcium oxide; $\mathrm{CaCO}_{3}$, calcium carbonate (calcite); $\mathrm{SiO}_{2}$, silicon dioxide; $\mathrm{Al}_{2} \mathrm{O}_{3}$, aluminum oxide; $\mathrm{MnO}$, manganese oxide; $\mathrm{Rb}$, rubidium; $\mathrm{Sr}$, strontium; $\mathrm{Th}$, thorium; $\mathrm{U}$, uranium; \%o, permil]

\begin{tabular}{|c|c|c|c|c|c|c|c|c|c|c|c|c|c|c|c|}
\hline $\begin{array}{c}\text { Sample } \\
\text { identification } \\
\text { No. }\end{array}$ & $\begin{array}{c}\text { Percent } \\
\text { sample } \\
\text { dissolved }\end{array}$ & MgO & $\mathrm{CaO}$ & $\begin{array}{c}\text { Mole } \\
\text { percent } \\
\mathrm{CaCO}_{3}\end{array}$ & $\mathrm{SiO}_{2}$ & $\mathrm{Al}_{2} \mathrm{O}_{3}$ & MnO & $\mathbf{R b}$ & $\mathrm{Sr}$ & Th & $\mathbf{U}$ & $\begin{array}{c}{ }^{87} \mathrm{Sr} /{ }^{86} \mathrm{Sr} \\
( \pm 0.00005 \\
2 \sigma)\end{array}$ & $\begin{array}{c}\delta^{87} \mathrm{Sr}, \% 0 \\
( \pm 0.072 \sigma)\end{array}$ & $\begin{array}{c}\boldsymbol{\delta}^{87} \mathbf{S r}_{\mathbf{t}^{\prime}} \\
\% 0\end{array}$ & $\begin{array}{c}\text { Seawater } \\
{ }^{87} \mathrm{Sr}^{86} \mathrm{Sr}_{\mathrm{psw}} \\
\text { used }\end{array}$ \\
\hline Army 1(862) & 69.2 & 18.2 & 31.8 & 55.6 & 1.69 & 1.10 & .017 & 6.73 & 69.6 & 4.02 & .55 & .71132 & 2.99 & 3.27 & .7090 \\
\hline Army 1(982)A & 97.9 & 22.9 & 30.2 & 48.7 & .22 & .01 & .026 & $<.87$ & 30.7 & $<.26$ & $<.26$ & .71027 & 1.51 & 1.65 & .7091 \\
\hline Army 1(982)B & 98.5 & 17.4 & 36.2 & 59.9 & .23 & .02 & .018 & $<.88$ & 37.9 & $<.26$ & $<.26$ & .71023 & 1.45 & 1.59 & .7091 \\
\hline ER3-1(2280) & 98.8 & 2.6 & 50.0 & 93.2 & $<.20$ & .02 & .027 & $<.94$ & 543 & $<.28$ & $<.28$ & .70958 & .54 & .54 & .7092 \\
\hline ER3-1(2580) & 99.7 & 1.1 & 49.3 & 96.9 & $<.22$ & .01 & .004 & $<1.04$ & 243 & $<.31$ & $<.31$ & .70935 & .20 & .20 & .7092 \\
\hline ER5-3 2(4780) & 99.4 & 17.2 & 35.0 & 59.3 & $<.20$ & .03 & .014 & $<.93$ & 79.4 & $<.27$ & $<.27$ & .71084 & 2.32 & 3.17 & .7086 \\
\hline ER6-1 2(2170) & 99.1 & 23.0 & 30.5 & 48.8 & $<.20$ & .02 & .011 & $<.95$ & 60.2 & $<.28$ & .75 & .70809 & -1.57 & -.02 & .7082 \\
\hline ER6-1 2(2630) & 100.0 & 23.0 & 30.6 & 48.9 & $<.17$ & .01 & .015 & $<.80$ & 53.2 & $<.24$ & .54 & .70816 & -1.47 & -.06 & .7082 \\
\hline ER6-2(2379) & 97.7 & 21.1 & 33.9 & 53.6 & .47 & $<.08$ & .014 & $<.84$ & 47.0 & $<.26$ & .59 & .71042 & 1.73 & 2.15 & .7089 \\
\hline ER6-2(2613) & 98.0 & .71 & 51.4 & 98.1 & .39 & .01 & .005 & $<1.02$ & 103 & $<.29$ & .66 & .70897 & -.33 & .94 & .7083 \\
\hline ER6-2(2721.5) & 98.5 & .95 & 50.8 & 97.5 & .36 & $<.08$ & .006 & $<.80$ & 97.6 & $<.25$ & .33 & .71103 & 2.58 & 3.86 & .7083 \\
\hline ER7-1(2150) & 90.9 & .59 & 56.0 & 98.5 & $<.24$ & .03 & .007 & $<1.12$ & 425 & $<.34$ & .39 & .70889 & -.44 & -.01 & .7089 \\
\hline ER7-1(2390) & 96.9 & .49 & 55.5 & 98.8 & $<.18$ & .02 & .004 & $<.86$ & 452 & .38 & .36 & .70884 & -.50 & -.08 & .7089 \\
\hline ER12-1(1720) & 51.2 & 18.2 & 36.1 & 58.7 & .68 & .45 & .053 & 4.78 & 297 & 1.94 & 2.14 & .71406 & 6.86 & 8.70 & .7079 \\
\hline ER12-1(3340) & 97.5 & 23.2 & 31.8 & 49.6 & $<.21$ & .01 & .016 & $<.96$ & 40.1 & $<.29$ & 1.12 & .71013 & 1.32 & 3.15 & .7079 \\
\hline ER12-3(3620) & 97.4 & 22.7 & 31.3 & 49.8 & $<.18$ & $<.08$ & .012 & $<.84$ & 105 & $<.25$ & .30 & .70908 & -.16 & .26 & .7089 \\
\hline ER12-3(4490) & 77.3 & .70 & 53.7 & 98.2 & 1.01 & .31 & .015 & 2.08 & 1,190 & .67 & 2.54 & .70937 & .24 & .24 & .7092 \\
\hline ER12-3(4840) & 72.1 & 1.10 & 53.0 & 97.2 & 1.29 & $>.45$ & .037 & 3.89 & 1,420 & .83 & 5.43 & .70928 & .11 & .11 & .7092 \\
\hline ER12-4(2580) & 97.9 & 22.1 & 30.6 & 50.0 & .66 & .18 & .036 & 3.91 & 146 & .30 & .29 & .71215 & 4.16 & 4.73 & .7088 \\
\hline UE1c(1790) & 97.0 & .27 & 51.6 & 99.3 & .23 & .03 & .005 & $<.95$ & 405 & .63 & .74 & .70879 & -.58 & -.02 & .7088 \\
\hline UE1c(1860) & 77.5 & 1.15 & 50.1 & 96.9 & 1.02 & .44 & .150 & 3.75 & 327 & 2.04 & .66 & .70945 & .35 & .63 & .7090 \\
\hline UE1h(2960) & 99.8 & 22.1 & 30.5 & 49.9 & .21 & .01 & .012 & $<1.00$ & 46.5 & $<.31$ & .76 & .70811 & -1.54 & -1.40 & .7091 \\
\hline UE2ce(1440) & 100.0 & 21.6 & 30.5 & 50.4 & .22 & .03 & .015 & $<.94$ & 24.3 & $<.29$ & $<.29$ & .70854 & -.94 & -.09 & .7086 \\
\hline UE7nS(2052.2) & 56.6 & .21 & 52.3 & 99.4 & .65 & .26 & .050 & 1.68 & 292 & 3.9 & .57 & .71111 & 2.70 & 3.12 & .7089 \\
\hline UE7nS(2190) & 80.3 & .17 & 52.2 & 99.6 & .39 & .10 & .036 & $<1.04$ & 276 & .93 & .4 & .71134 & 3.02 & 3.30 & .7090 \\
\hline UE10j(1290) & 98.3 & 22.9 & 29.8 & 48.4 & $<.18$ & .02 & .015 & $<.82$ & 39.2 & $<.24$ & $<.24$ & .70870 & -.71 & -.42 & .7090 \\
\hline UE10j(1863) & 94.1 & 22.9 & 29.4 & 48.0 & .21 & .04 & .023 & $<.89$ & 64.9 & $<.26$ & .83 & .70862 & -.82 & -.53 & .7090 \\
\hline UE10j(2051) & 24.5 & 11.5 & 19.0 & 54.4 & 9.28 & $>3.87$ & .170 & 58 & 299 & 27.2 & $<1.21$ & .72089 & 16.49 & 16.49 & .7092 \\
\hline UE10j(2154) & 98.9 & 22.7 & 29.8 & 48.5 & $<.18$ & .02 & .099 & $<.83$ & 35 & $<.24$ & $<.24$ & .70873 & -.66 & -.52 & .7091 \\
\hline UE15d(5960) & 97.3 & 21.6 & 31.2 & 51.0 & .32 & .10 & .015 & $<.80$ & 34.2 & $<.25$ & 1.19 & .71300 & 5.36 & 6.49 & .7084 \\
\hline UE15d(5994) & 96.1 & 20.4 & 30.9 & 52.1 & .59 & .17 & .010 & 1.96 & 37.4 & $<.25$ & $<.25$ & .71370 & 6.34 & 7.48 & .7084 \\
\hline UE16d(1020) & 98.9 & .60 & 47.0 & 98.3 & .26 & .04 & .001 & $<1.02$ & 1,680 & $<.30$ & 2.18 & .70828 & -1.30 & -.03 & .7083 \\
\hline UE16d(1550) & 4.1 & $<1.89$ & 31.5 & 96.0 & 6.23 & 1.68 & .234 & $<22.9$ & 660 & $<7.04$ & $<7.04$ & .70889 & -.43 & .84 & .7083 \\
\hline
\end{tabular}


In contrast, three leachate samples with 0.95 to 11.5 weight percent $\mathrm{MgO}$ concentrations plot off the calcitedolomite mixing trend and have elevated $\mathrm{SiO}_{2}$ concentrations compared to other carbonate leachates (solid squares, fig. 4). These leachates -ER16-1 (3540), UE10j (2051), and UE16d (1550) — also had the lowest percent-sample-dissolved values (4.1 to 24.5 percent) and contained noticeable clay or volcanic constituents. These observations indicate that chemical compositions of these leachates are not derived exclusively from carbonate components and likely include ions leached from silicate minerals.

Measurable amounts of $\mathrm{SiO}_{2}$ and $\mathrm{Al}_{2} \mathrm{O}_{3}$ in leachates indicates that small amounts of clay minerals may be present in many of the carbonate samples. The positive correlation between $\mathrm{SiO}_{2}$ and $\mathrm{Al}_{2} \mathrm{O}_{3}$ concentrations with a $\mathrm{SiO}_{2}: \mathrm{Al}_{2} \mathrm{O}_{3}$ weight ratio of $2: 1$ (fig. $5 \mathrm{~A}$ ) could be the result of variable amounts of clay minerals mixed in with the marine carbonate rocks. Systematic differences in $\mathrm{SiO}_{2}$ concentrations between dolomite and limestone samples are not apparent (fig. 5B).

Concentrations of Sr vary widely, but systematically, in the carbonate fractions of the 2006 borehole samples (fig. 6). Limestone samples have $\mathrm{Sr}$ concentrations ranging from 97.5 to 1,680 micrograms per gram $(\mu \mathrm{g} / \mathrm{g})$ with a median value of $384.5 \mu \mathrm{g} / \mathrm{g}(\mathrm{N}=16)$ whereas dolomite samples have Sr concentrations ranging from 16.9 to $146 \mu \mathrm{g} / \mathrm{g}$ with a median value of $46.5 \mu \mathrm{g} / \mathrm{g}(\mathrm{N}=21)$. Carbonate samples with $\mathrm{CaCO}_{3}$ mole percentages between 55 and 74 percent have intermediate $\mathrm{Sr}$ concentrations with a median value of $140 \mu \mathrm{g} /$ $\mathrm{g}(\mathrm{N}=11)$.

Concentrations of $\mathrm{Rb}$ in leachates of most samples are less than the minimum reporting limits of around $1 \mu \mathrm{g} / \mathrm{g}$ (table 5). Rb concentrations generally increase with increasing $\mathrm{SiO}_{2}$ (fig. 7A) indicating that silicate minerals (most likely clays) are a repository of $\mathrm{Rb}$. Dolomite and limestone samples have similar $\mathrm{Rb}$ concentrations, but because of their lower $\mathrm{Sr}$ concentrations, dolomite samples tend to have higher $\mathrm{Rb} / \mathrm{Sr}$ ratios (fig. 7B). Most samples have $\mathrm{Rb} / \mathrm{Sr}$ ratios less than about 0.05 . For a Cambrian marine carbonate sample with a $\mathrm{Rb} / \mathrm{Sr}$ ratio of 0.05 and an initial ${ }^{87} \mathrm{Sr} /{ }^{86} \mathrm{Sr}$ value of 0.70900 $\left(\delta^{87} \mathrm{Sr}=-0.28\right)$, the decay of ${ }^{87} \mathrm{Rb}$ during the last $500 \mathrm{~m} . \mathrm{y}$. will result in a present-day ${ }^{87} \mathrm{Sr} /{ }^{86} \mathrm{Sr}$ value of $0.71003\left(\delta^{87} \mathrm{Sr}=1.17\right)$, an increase of about one in the third decimal place. If the same rock had a $\mathrm{Rb} / \mathrm{Sr}$ ratio of 0.015 (the upper limit for most dolomite and limestone samples, fig. 7B), the present-day ${ }^{87} \mathrm{Sr} /{ }^{86} \mathrm{Sr}$ ratio would only evolve to $0.70931\left(\delta^{87} \mathrm{Sr}=0.15\right)$. Only four clay-rich samples have $\mathrm{Rb} / \mathrm{Sr}$ ratios higher than 0.056 (fig. 7B).

Additional elements reported in table 5 include $\mathrm{MnO}$, Th, and U. Concentrations of $\mathrm{MnO}$ are statistically uncorrelated with mole percent $\mathrm{CaCO}_{3}$ contents (linear correlation coefficient, $\mathrm{r}^{2}$, of 0.035 ) although the highest $\mathrm{MnO}$ concentrations are present in limestones. Samples with the lowest $\mathrm{SiO}_{2}$ concentrations also tend to have the lowest $\mathrm{MnO}$ and Th concentrations indicating the potential influence of clay minerals and the low solubility of these constituents in marine environments. In contrast, $\mathrm{U}$ concentrations are uncorrelated statistically with $\mathrm{SiO}_{2}$ and are present in similar concentration ranges in dolomite and limestone samples.

Because $\mathrm{CaO}$ and $\mathrm{MgO}$ concentrations are not available from XRF analyses, quantification of calcite mole percentages in outcrop samples was not possible. Bulk-rock Sr concentrations range from 16 to $2,537 \mu \mathrm{g} / \mathrm{g}$ with most samples having between about 30 and $500 \mu \mathrm{g} / \mathrm{g}$ (table 6). Samples with $\mathrm{Sr}$ concentrations greater than $500 \mu \mathrm{g} / \mathrm{g}$ typically increase along with $\mathrm{Zr}$ concentrations (fig. 8A). Because $\mathrm{Zr}$ is a highly insoluble element in marine environments (mean $\mathrm{Zr}$ concentration in North Pacific Ocean water is $0.000015 \mu \mathrm{g} / \mathrm{g}$; McKelvey and Orians, 1993) compared to $\mathrm{Sr}$ (mean seawater Sr concentration of $7.74 \mu \mathrm{g} / \mathrm{g}$; Faure and Mensing, 2005, p. 437), Sr concentrations greater than $500 \mu \mathrm{g} / \mathrm{g}$ in outcrop samples likely are attributable to silicate constituents included in the rock. Concentrations of Rb typically cluster at values less than $5 \mu \mathrm{g} / \mathrm{g}$ and are not correlated with $\mathrm{Sr}$ concentrations $\left(\mathrm{r}^{2}\right.$ value of 0.039 in fig. 8B). However, the crude correlation between $\mathrm{Rb}$ and $\mathrm{Zr}$ concentration ( $\mathrm{r}^{2}$ value of 0.43 in fig. $8 \mathrm{C}$ ) implies that both constituents are derived from terrigenous silicate components. Therefore, outcrop samples with the lowest $\mathrm{Zr}$ concentrations best represent the carbonate fraction of these bulk-rock analyses. A frequency distribution plot of $\mathrm{Sr}$ concentrations in samples having $\mathrm{Zr}$ concentrations less than $20 \mu \mathrm{g} / \mathrm{g}$ (fig. 8D) indicates a narrow frequency peak between 25 and $75 \mu \mathrm{g} / \mathrm{g}$ (mostly classified as dolomites in field descriptions) and a broader frequency peak between 100 and $400 \mu \mathrm{g} / \mathrm{g}$ (mostly classified as limestones). 

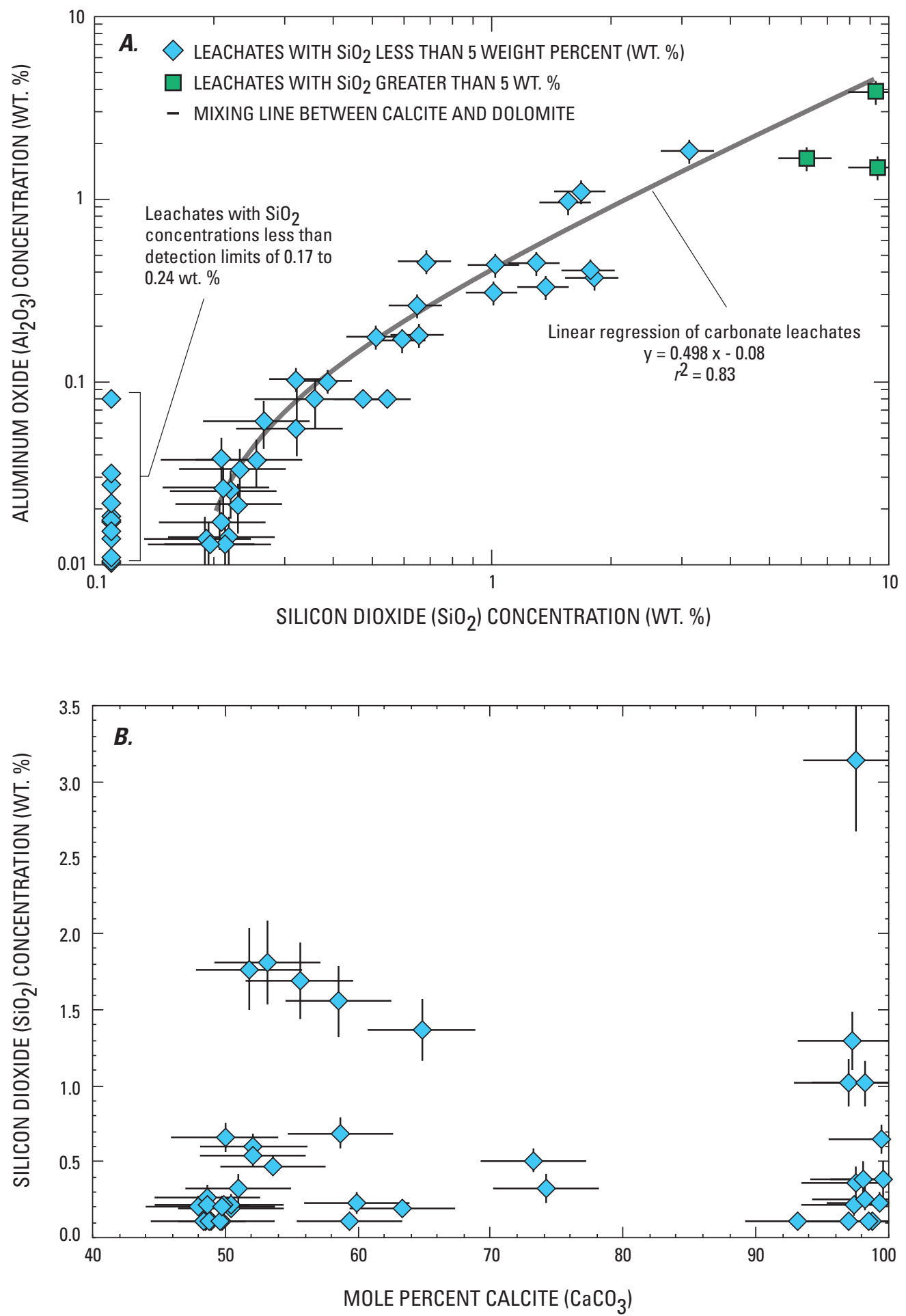

Figure 5. Relation between $(A)$ silicon dioxide $\left(\mathrm{SiO}_{2}\right)$ and aluminum oxide $\left(\mathrm{Al}_{2} \mathrm{O}_{3}\right)$ concentrations and between $(B)$ silicon dioxide and mole percent calcite $\left(\mathrm{CaCO}_{3}\right)$ in acid leachates of borehole samples, Nevada Test Site, Nye County, Nevada. Error bars represent 2-sigma analytical uncertainty and are shown as 30 percent of the reported concentration value for $\mathrm{Al}_{2} \mathrm{O}_{3}$ values less than $0.1 \mathrm{wt}$. $\%$ and $\mathrm{SiO}_{2}$ values less than $0.4 \mathrm{wt}$. $\%$, and 15 percent for higher concentration values. 

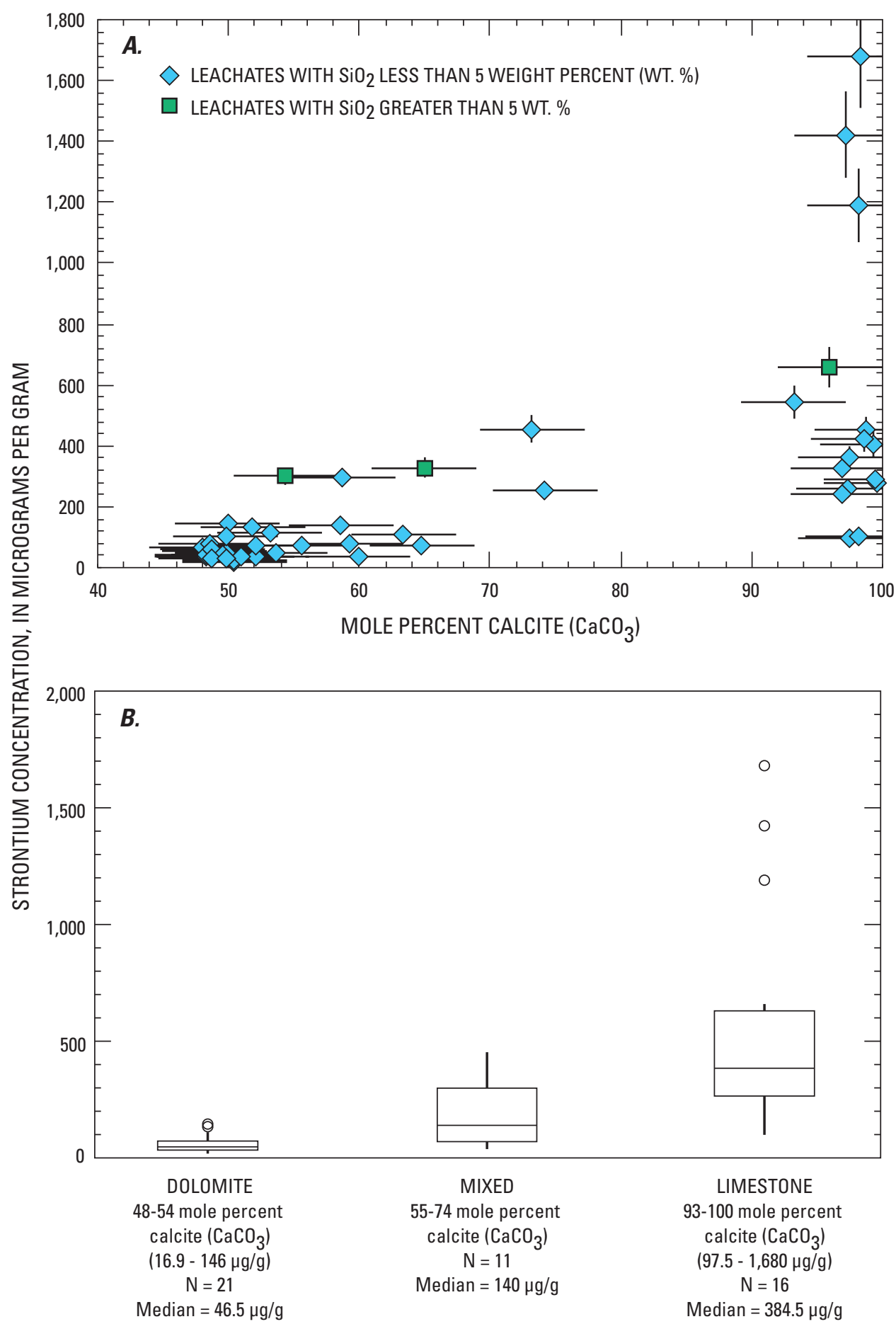

Figure 6. Relation between $(A)$ strontium $(\mathrm{Sr})$ concentration and mole percent calcite $\left(\mathrm{CaCO}_{3}\right)$ in acid leachates of borehole samples, and $(B)$ distribution of strontium concentrations for acid leachates, Nevada Test Site, Nye County, Nevada. Error bars represent 2-sigma analytical uncertainty and are shown as 10 percent of the reported concentration value for strontium and are fixed at 4 mole percent $\mathrm{CaCO}_{3}$. 

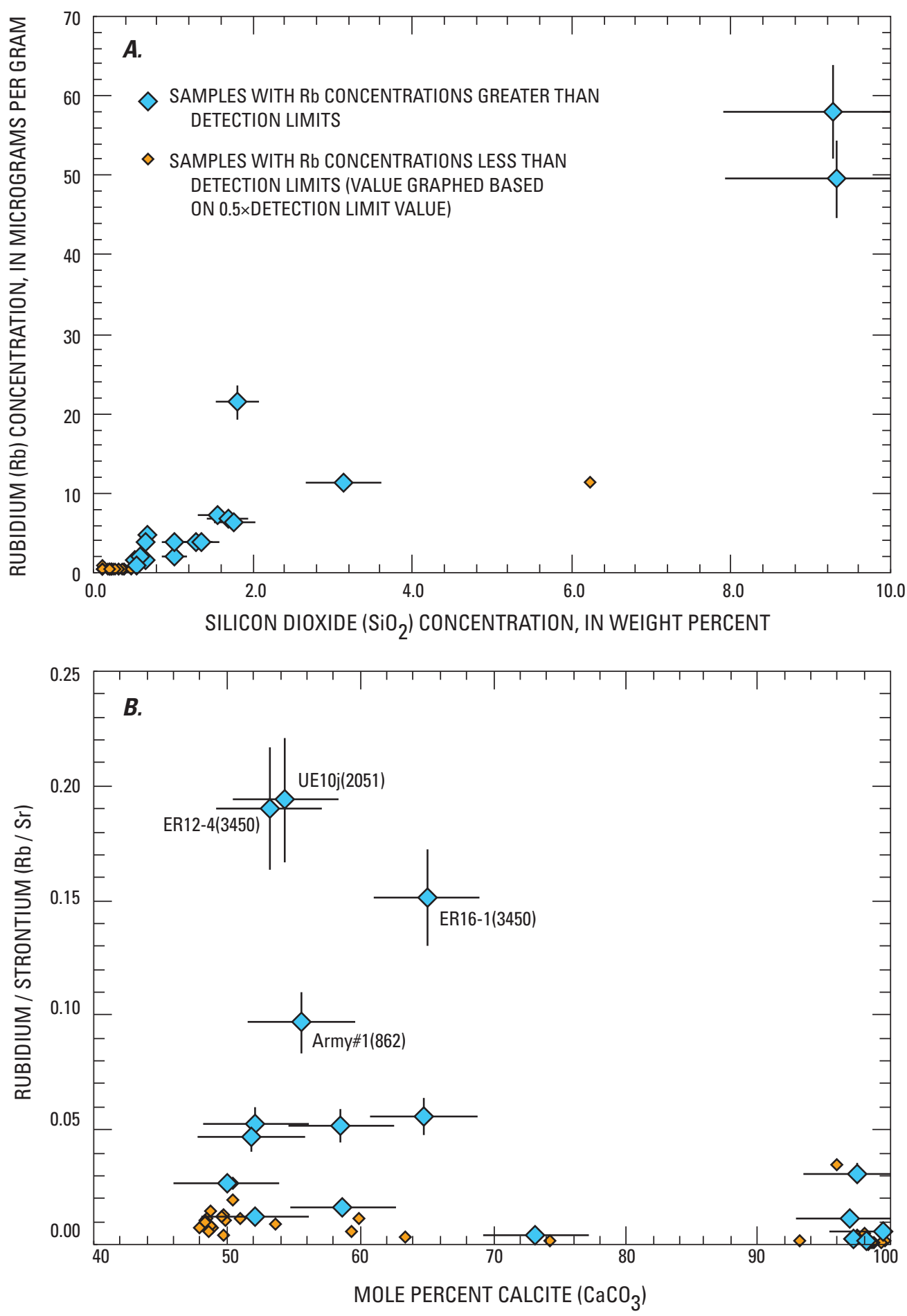

Figure 7. Relation between $(A)$ rubidium $(\mathrm{Rb})$ and silicon dioxide $\left(\mathrm{SiO}_{2}\right)$ concentrations in acid leachates of borehole samples and between $(B)$ rubidium/strontium $(\mathrm{Rb} / \mathrm{Sr})$ concentration ratios and mole percent calcite $\left(\mathrm{CaCO}_{3}\right)$ in acid leachates of borehole samples, Nevada Test Site, Nye County, Nevada. Error bars represent 2-sigma analytical uncertainty and are shown as 10 percent of the reported concentration value for rubidium values and 14 percent for rubidium/strontium values. Mole percentages of calcite are shown with fixed 2-sigma analytical uncertainties of 4 mole percent $\mathrm{CaCO}_{3}$. 
Table 6. Bulk-rock analyses of selected trace element concentrations and strontium isotopic compositions $\left({ }^{87} \mathrm{Sr} /{ }^{86} \mathrm{Sr}\right)$ in outcrop samples collected in the early 1990s from the Nevada Test Site vicinity, Clark, Lincoln, and Nye Counties, Nevada, and Inyo County, California.

[Trace element ( $\mathrm{Rb}, \mathrm{Sr}, \mathrm{Zr}, \mathrm{Ba}, \mathrm{La}$, and $\mathrm{Ce})$ concentrations were determined by $\mathrm{X}$-ray fluorescence on whole-rock samples and are given in micrograms per gram $(\mu \mathrm{g} / \mathrm{g})$. Concentrations below minimum reporting limits are indicated as "0". "ND" indicates that concentrations were not determined. All strontium isotopic compositions $\left({ }^{87} \mathrm{Sr} /{ }^{86} \mathrm{Sr}\right)$ were determined on dilute hydrochloric acid leachates of powdered rock samples with the exception of two samples (map numbers 4 and 5 marked with asterisks) which were determined on whole-rock digestions. ${ }^{87} \mathrm{Sr} /{ }^{86} \mathrm{Sr}$ uncertainties are typically, but not always, dominated by external error associated with reproducibility of the EN-1 standard $( \pm 0.00005)$. Strontium isotopic compositions are also given in delta notation $\left({ }^{87} \mathrm{Sr}\right)=\left[\left({ }^{87} \mathrm{Sr}{ }^{86} \mathrm{Sr} r_{\text {sample }}{ }^{87} \mathrm{Sr} /\right.\right.$ $\left.\left.{ }^{86} \mathrm{Sr}_{\mathrm{psw}}\right)-1\right] \times 1,000$, where ${ }^{87} \mathrm{Sr} /{ }^{86} \mathrm{Sr}_{\text {msw }}$ is the value for modern seawater and ${ }^{87} \mathrm{Sr}^{86} \mathrm{Sr}_{\mathrm{psw}}$ is the value for paleoseawater at the time of deposition. $\delta^{87} \mathrm{Sr}_{t}$ values for rocks underlying the Wood Canyon Formation were not calculated (NC) because of the very large uncertainties in assigning ages and initial seawater ${ }^{87} \mathrm{Sr} /{ }^{86} \mathrm{Sr}$ values, which are designated as "undefined" Abbreviations and symbols: Rb, rubidium; Sr, strontium; Zr, zirconium; La, lanthanum; Ce, cerium; \%o, per mil]

\begin{tabular}{|c|c|c|c|c|c|c|c|c|c|c|c|c|c|c|c|}
\hline $\begin{array}{l}\text { Map } \\
\text { No. }\end{array}$ & $\begin{array}{c}\text { Sample } \\
\text { No. }\end{array}$ & $\begin{array}{l}\text { Rock } \\
\text { type }\end{array}$ & $\mathbf{R b}$ & Sr & $\mathrm{Zr}$ & $\mathrm{Ba}$ & La & $\mathrm{Ce}$ & ${ }^{87} \mathrm{Sr} /{ }^{86} \mathrm{Sr}$ & $\pm 2 \sigma$ & $\begin{array}{c}\delta^{87} \mathrm{Sr} \\
\% 0\end{array}$ & $\pm 2 \sigma$ & Unit & $\begin{array}{c}\delta^{87} \mathbf{S r}_{t} \\
\% 0\end{array}$ & $\begin{array}{c}\text { Seawater } \\
{ }^{87} \mathrm{Sr} /{ }^{86} \mathrm{Sr}_{\text {psw }} \\
\text { used }\end{array}$ \\
\hline 2 & HD-1111 & Marble & 7 & 1,453 & 40 & 191 & 0 & 4 & .70727 & .00005 & -2.72 & .07 & $\mathrm{Yc}$ & $\mathrm{NC}$ & Undefined \\
\hline 3 & HD-1112 & Marble & 3.3 & 1,614 & 55 & 187 & 6 & 13 & .70735 & .00005 & -2.61 & .07 & Yc & $\mathrm{NC}$ & Undefined \\
\hline 6 & HD-1105 & Dolomite & 5 & 75 & 31 & 126 & 33 & 60 & .71343 & .00005 & 5.97 & .07 & Zs-c & $\mathrm{NC}$ & Undefined \\
\hline 7 & HD-1151 & Limestone & 8 & 1164 & 59 & 25 & 13 & 7 & .70945 & .00005 & .35 & .07 & $\mathrm{CZw}$ & 1.48 & 0.7084 \\
\hline 8 & $3 \mathrm{C}-1$ & Carbonate & 2.5 & 221 & 10 & 30 & 18 & 13 & .71106 & .00005 & 2.62 & .07 & $\mathrm{Cb}$ & 2.76 & .7091 \\
\hline 9 & HD-212 & Dolomite & 0 & 146 & 1 & ND & ND & ND & .71181 & .00005 & 3.68 & .07 & $\mathrm{Cb}-\mathrm{b}$ & 3.68 & .7092 \\
\hline 10 & HD-214 & Dolomite & 0 & 211 & 0 & ND & ND & ND & .71279 & .00008 & 5.06 & .11 & $\mathrm{Cb}-\mathrm{b}$ & 5.06 & .7092 \\
\hline 11 & HD-216 & Dolomite & 0 & 256 & 0 & ND & ND & ND & .71125 & .00005 & 2.89 & .07 & $\mathrm{Cb}-\mathrm{b}$ & 2.89 & .7092 \\
\hline 15 & HD-221 & Dolomite & 0 & 268 & 0 & ND & ND & ND & .71070 & .00005 & 2.12 & .07 & $\mathrm{Cb}-\mathrm{b}$ & 2.12 & .7092 \\
\hline 16 & HD-1154 & Limestone & 24 & 261 & 124 & 180 & 14 & 30 & .72543 & .00005 & 22.89 & .07 & $\mathrm{CZw}-\mathrm{u}$ & 24.0 & .7084 \\
\hline 17 & HD-1155 & Limestone & 7 & 445 & 93 & 47 & 19 & 49 & .71958 & .00005 & 14.64 & .07 & $\mathrm{CZw}$ & 15.8 & .7084 \\
\hline 18 & HD-538 & Marble & .6 & 245 & 4 & 45 & 8 & 7 & .70921 & .00005 & .01 & .07 & $\mathrm{Cb}-\mathrm{p}$ & .30 & .7090 \\
\hline 19 & HD-539 & Dolomite & .6 & 28 & 0 & 34 & 20 & 16 & .70999 & .00005 & 1.11 & .07 & $\mathrm{Cb}-\mathrm{p}$ & 1.39 & .7090 \\
\hline 20 & HD-540 & Dolomite & .6 & 23 & 0 & 31 & 8 & 12 & .70922 & .00005 & .03 & .07 & Cb-p & .31 & .7090 \\
\hline 21 & HD-541 & $\begin{array}{l}\text { Calcitic } \\
\text { marble }\end{array}$ & 2.8 & 636 & 27 & 149 & 15 & 37 & .72141 & .00005 & 17.21 & .07 & $\mathrm{CZw}-\mathrm{u}$ & 18.4 & .7084 \\
\hline 22 & HD-513 & Dolomite & 2.4 & 96 & 16 & 37 & 28 & 2 & .70946 & .00005 & .37 & .07 & Oes & 1.35 & .7085 \\
\hline 23 & HD-515 & Dolomite & 1.3 & 58 & 1 & 42 & 8 & 2 & .70875 & .00005 & -.64 & .07 & Oes & .35 & .7085 \\
\hline 24 & HD-516A & Dolomite & 2.4 & 71 & 9 & 42 & 28 & 2 & .70981 & .00008 & .86 & .11 & $\mathrm{Sr}$ & 1.42 & .7088 \\
\hline 25 & HD-517 & Limestone & 16 & 311 & 36 & 88 & 22 & 16 & .71319 & .00005 & 5.63 & .07 & $\mathrm{Sr}$ & 6.19 & .7088 \\
\hline 33 & HD-1416 & Carbonate & 0 & 177 & 5 & 0 & 13 & 0 & .71323 & .00005 & 5.68 & .07 & Cb-p & 5.97 & .7090 \\
\hline 34 & HD-1417 & Carbonate & 0 & 979 & 47 & 34 & 12 & 38 & .71829 & .00005 & 12.82 & .07 & $\mathrm{CZw}-1$ & 14.0 & .7084 \\
\hline 35 & HD-1418 & Carbonate & 0 & 151 & 2 & 0 & 0 & 0 & .72260 & .00005 & 18.9 & .07 & $\mathrm{CZw}-1$ & 20.0 & .7084 \\
\hline 36 & HD-1419 & Carbonate & 0 & 166 & 4 & 2 & 15 & 11 & .72327 & .00005 & 19.84 & .07 & Cb-p & 20.1 & .709 \\
\hline 37 & HD-1420 & Carbonate & 0 & 66 & 1 & 0 & 6 & 0 & .71905 & .00005 & 13.89 & .07 & Cb-p & 14.2 & .709 \\
\hline 38 & HD-1421 & Carbonate & 2.8 & 627 & 28 & 47 & 13 & 31 & .71374 & .00005 & 6.40 & .07 & CZw-1 & 7.54 & .7084 \\
\hline 39 & HD-527 & Dolomite & .6 & 47 & 0 & 25 & 18 & 10 & .70816 & .00007 & -1.47 & .10 & Df & .37 & .7079 \\
\hline 40 & HD-528 & Dolomite & 1.1 & 60 & 0 & 39 & 8 & 11 & .71152 & .00005 & 3.27 & .07 & Df & 5.11 & .7079 \\
\hline 41 & HD-529 & $\begin{array}{l}\text { Calcitic } \\
\text { marble }\end{array}$ & 3 & 166 & 0 & 41 & 8 & 2 & .71017 & .00005 & 1.36 & .07 & $\mathrm{Cb}-\mathrm{b}$ & 1.36 & .7092 \\
\hline 42 & HD-530 & $\begin{array}{c}\text { Dolomitic } \\
\text { marble }\end{array}$ & .6 & 27 & 0 & 33 & 16 & 2 & .70927 & .00005 & .10 & .07 & $\mathrm{Cb}-\mathrm{b}$ & .10 & .7092 \\
\hline
\end{tabular}


Table 6. Bulk-rock analyses of selected trace element concentrations and strontium isotopic compositions $\left({ }^{87} \mathrm{Sr} /{ }^{86} \mathrm{Sr}\right)$ in outcrop samples collected in the early 1990s from the Nevada Test Site vicinity, Clark, Lincoln, and Nye Counties, Nevada, and Inyo County, California.-Continued

[Trace element ( $\mathrm{Rb}, \mathrm{Sr}, \mathrm{Zr}, \mathrm{Ba}, \mathrm{La}$, and $\mathrm{Ce}$ ) concentrations were determined by X-ray fluorescence on whole-rock samples and are given in micrograms per gram $(\mu \mathrm{g} / \mathrm{g})$. Concentrations below minimum reporting limits are indicated as "0". "ND" indicates that concentrations were not determined. All strontium isotopic compositions ${ }^{87} \mathrm{Sr} /{ }^{86} \mathrm{Sr}$ ) were determined on dilute hydrochloric acid leachates of powdered rock samples with the exception of two samples (map numbers 4 and 5 marked with asterisks) which were determined on whole-rock digestions. ${ }^{87} \mathrm{Sr} /{ }^{86} \mathrm{Sr}$ uncertainties are typically, but not always, dominated by external error associated with reproducibility of the EN-1 standard $( \pm 0.00005)$. Strontium isotopic compositions are also given in delta notation $\left(\delta^{87} \mathrm{Sr}\right)=\left[\left({ }^{87} \mathrm{Sr}{ }^{86} \mathrm{Sr} r_{\text {sample }}{ }^{87} \mathrm{Sr} /\right.\right.$ ${ }^{86} \mathrm{Sr}_{\mathrm{psw}}$ ) -1$] \times 1,000$, where ${ }^{87} \mathrm{Sr}^{86}{ }^{86} \mathrm{Sr}_{\mathrm{msw}}$ is the value for modern seawater and ${ }^{87} \mathrm{Sr} /{ }^{86} \mathrm{Sr}_{\mathrm{psw}}$ is the value for paleoseawater at the time of deposition. $\delta^{87} \mathrm{Sr}_{\mathrm{t}}$ values for rocks underlying the Wood Canyon Formation were not calculated (NC) because of the very large uncertainties in assigning ages and initial seawater ${ }^{87} \mathrm{Sr} /{ }^{86} \mathrm{Sr}$ values, which are designated as "undefined" Abbreviations and symbols: Rb, rubidium; Sr, strontium; Zr, zirconium; La, lanthanum; Ce, cerium; \%o, per mil]

\begin{tabular}{|c|c|c|c|c|c|c|c|c|c|c|c|c|c|c|c|}
\hline $\begin{array}{l}\text { Map } \\
\text { No. }\end{array}$ & $\begin{array}{c}\text { Sample } \\
\text { No. }\end{array}$ & $\begin{array}{l}\text { Rock } \\
\text { type }\end{array}$ & $\mathbf{R b}$ & Sr & $\mathrm{Zr}$ & $\mathrm{Ba}$ & La & $\mathrm{Ce}$ & ${ }^{87} \mathrm{Sr} /{ }^{86} \mathrm{Sr}$ & $\pm 2 \sigma$ & $\begin{array}{c}\boldsymbol{\delta}^{87} \mathbf{S r} \\
\% 0\end{array}$ & $\pm 2 \sigma$ & Unit & $\begin{array}{c}\delta^{87} \mathbf{S r}_{t} \\
\% 0\end{array}$ & $\begin{array}{c}\text { Seawater } \\
{ }^{87} \mathrm{Sr} /{ }^{86} \mathrm{Sr}_{\mathrm{psw}} \\
\text { used }\end{array}$ \\
\hline 44 & HD-542 & $\begin{array}{c}\text { Dolomitic } \\
\text { marble }\end{array}$ & 4.5 & 371 & 8 & 39 & 20 & 28 & .71010 & .00005 & 1.27 & .07 & $\mathrm{CZw}-1$ & 2.40 & .7084 \\
\hline 47 & HD-1153 & Limestone & 3 & 306 & 12 & 13 & 14 & 25 & .71125 & .00005 & 2.89 & .07 & Zs-d & $\mathrm{NC}$ & Undefined \\
\hline 48 & HD-1142 & Limestone & 6 & 390 & 18 & 29 & 0 & 0 & .70876 & .00005 & -.62 & .07 & Op-g & -.20 & .7089 \\
\hline 49 & HD-1144 & Limestone & 2 & 35 & 14 & 58 & 14 & 0 & .70935 & .00005 & .21 & .07 & Df & 2.04 & .7079 \\
\hline 50 & HD-1400 & Carbonate & 0 & 56 & 0 & 0 & 12 & 8 & .71265 & .00005 & 4.87 & .07 & $\mathrm{Cb}-\mathrm{b}$ & 4.87 & .7092 \\
\hline 55 & HD-1146 & Limestone & 0 & 283 & 8 & 147 & 4 & 0 & .71292 & .00005 & 5.25 & .07 & MDe & 6.95 & .7080 \\
\hline 56 & HD-1147a & Limestone & 14 & 197 & 20 & 140 & 8 & 12 & .70926 & .00005 & .09 & .07 & Dtc & .66 & .7088 \\
\hline 57 & HD-1147b & Limestone & 2 & 120 & 5 & 23 & 6 & 7 & .71088 & .00005 & 2.37 & .07 & Dtc & 2.93 & .7088 \\
\hline 58 & HD-522 & Dolomite & 1.3 & 63 & 0 & 101 & 29 & 27 & .70976 & .00008 & .79 & .11 & Dtc & 1.35 & .7088 \\
\hline 59 & HD-523 & Limestone & 6.7 & 172 & 7 & 141 & 8 & 13 & .71029 & .00005 & 1.53 & .07 & Dtc & 2.10 & .7088 \\
\hline 60 & HD-526 & Limestone & 2.5 & 668 & 20 & 55 & 13 & 6 & .71018 & .00007 & 1.38 & .10 & Cc-m & 2.37 & .7085 \\
\hline 61 & HD-1138 & Limestone & 9 & 777 & 40 & 37 & 12 & 0 & .70884 & .00005 & -.51 & .07 & Op-av & -.09 & .7089 \\
\hline 62 & HD-1139 & $\begin{array}{l}\text { Dolomite/ } \\
\text { limestone }\end{array}$ & 2 & 65 & 20 & 0 & 16 & 0 & .70935 & .00005 & .22 & .07 & DSlm & .78 & .7088 \\
\hline 63 & HD-1141 & Limestone & 10 & 1,140 & 54 & 57 & 14 & 0 & .70906 & .00005 & -.2 & .07 & Op-av & .22 & .7089 \\
\hline 64 & HD-1150b & Carbonate & 7 & 507 & 25 & 38 & 7 & 22 & .71722 & .00005 & 11.31 & .07 & $\mathrm{CZw}$ & 12.5 & .7084 \\
\hline 65 & HD-546 & Dolomite & .6 & 45 & 0 & 36 & 25 & 24 & .70886 & .00006 & -.48 & .08 & Dsi & 1.36 & .7079 \\
\hline 73 & HD-556 & Limestone & 3.2 & 362 & 9 & 50 & 8 & 7 & .70938 & .00005 & .25 & .07 & $\mathrm{Cb}-\mathrm{b}$ & .25 & .7092 \\
\hline 74 & HD-557 & Limestone & 1.9 & 207 & 3 & 36 & 15 & 2 & .70912 & .00005 & -.11 & .07 & $\mathrm{Cb}-\mathrm{p}$ & .03 & .7091 \\
\hline 75 & HD-558 & Limestone & 5.2 & 442 & 5 & 32 & 8 & 2 & .70918 & .00007 & -.03 & .10 & Cb-p & .11 & .7091 \\
\hline 76 & HD-1422-1 & Carbonate & 30.2 & 528 & 74 & 118 & 11 & 14 & .71255 & .00005 & 4.72 & .07 & $\mathrm{Cb}-\mathrm{b}$ & 4.72 & .7092 \\
\hline 77 & HD-1422-2 & Carbonate & 3 & 247 & 14 & 17 & 4 & 17 & .71103 & .00005 & 2.58 & .07 & $\mathrm{Cb}-\mathrm{b}$ & 2.58 & .7092 \\
\hline 78 & HD-1423 & Carbonate & 19.6 & 204 & 51 & 82 & 16 & 0 & .71003 & .00005 & 1.17 & .07 & $\mathrm{Cb}-\mathrm{b}$ & 1.17 & .7092 \\
\hline 79 & HD-1426 & Carbonate & 1.4 & 145 & 18 & 8 & 19 & 38 & .71243 & .00005 & 4.56 & .07 & $\mathrm{CZw}$ & 5.55 & .7085 \\
\hline 80 & HD-1427 & Carbonate & 3.8 & 334 & 20 & 10 & 0 & 0 & .70937 & .00005 & .24 & .07 & $\mathrm{Cb}-\mathrm{b}$ & .24 & .7092 \\
\hline 81 & HD-1428 & Carbonate & 0 & 175 & 5 & 0 & 6 & 5 & .70899 & .00005 & -.30 & .07 & $\mathrm{Cb}-\mathrm{b}$ & -.16 & .7091 \\
\hline 82 & HD-1429 & Carbonate & 3.3 & 292 & 14 & 10 & 9 & 4 & .70911 & .00005 & -.13 & .07 & $\mathrm{Cb}-\mathrm{b}$ & .01 & .7091 \\
\hline 83 & HD-1432 & Carbonate & 1.9 & 555 & 21 & 9 & 12 & 11 & .70931 & .00005 & .16 & .07 & $\mathrm{Cn}$ & .30 & .7091 \\
\hline
\end{tabular}


Table 6. Bulk-rock analyses of selected trace element concentrations and strontium isotopic compositions $\left({ }^{87} \mathrm{Sr} /{ }^{86} \mathrm{Sr}\right)$ in outcrop samples collected in the early 1990s from the Nevada Test Site vicinity, Clark, Lincoln, and Nye Counties, Nevada, and Inyo County, California.-Continued

[Trace element ( $\mathrm{Rb}, \mathrm{Sr}, \mathrm{Zr}, \mathrm{Ba}, \mathrm{La}$, and $\mathrm{Ce})$ concentrations were determined by $\mathrm{X}$-ray fluorescence on whole-rock samples and are given in micrograms per gram $(\mu \mathrm{g} / \mathrm{g})$. Concentrations below minimum reporting limits are indicated as "0". "ND" indicates that concentrations were not determined. All strontium isotopic compositions $\left({ }^{87} \mathrm{Sr} /{ }^{86} \mathrm{Sr}\right)$ were determined on dilute hydrochloric acid leachates of powdered rock samples with the exception of two samples (map numbers 4 and 5 marked with asterisks) which were determined on whole-rock digestions. ${ }^{87} \mathrm{Sr} /{ }^{86} \mathrm{Sr}$ uncertainties are typically, but not always, dominated by external error associated with reproducibility of the EN-1 standard $( \pm 0.00005)$. Strontium isotopic compositions are also given in delta notation $\left({ }^{87} \mathrm{Sr}\right)=\left[\left({ }^{87} \mathrm{Sr}{ }^{86} \mathrm{Sr} r_{\text {sample }}{ }^{87} \mathrm{Sr} /\right.\right.$ $\left.\left.{ }^{86} \mathrm{Sr}_{\mathrm{psw}}\right)-1\right] \times 1,000$, where ${ }^{87} \mathrm{Sr} /{ }^{86} \mathrm{Sr}_{\text {msw }}$ is the value for modern seawater and ${ }^{87} \mathrm{Sr}^{86} \mathrm{Sr}_{\mathrm{psw}}$ is the value for paleoseawater at the time of deposition. $\delta^{87} \mathrm{Sr}_{t}$ values for rocks underlying the Wood Canyon Formation were not calculated (NC) because of the very large uncertainties in assigning ages and initial seawater ${ }^{87} \mathrm{Sr} /{ }^{86} \mathrm{Sr}$ values, which are designated as "undefined" Abbreviations and symbols: Rb, rubidium; Sr, strontium; Zr, zirconium; La, lanthanum; Ce, cerium; \%o, per mil]

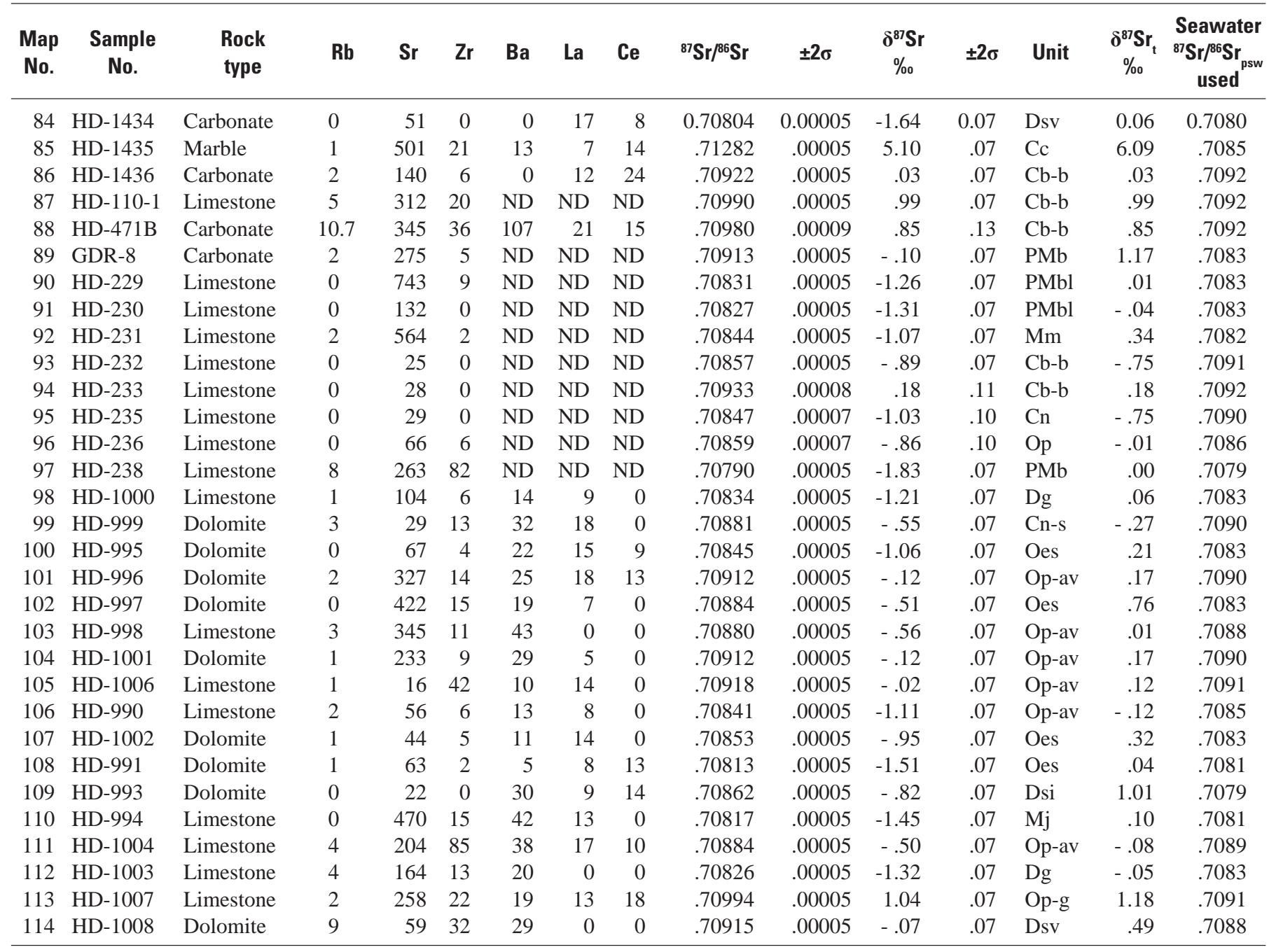



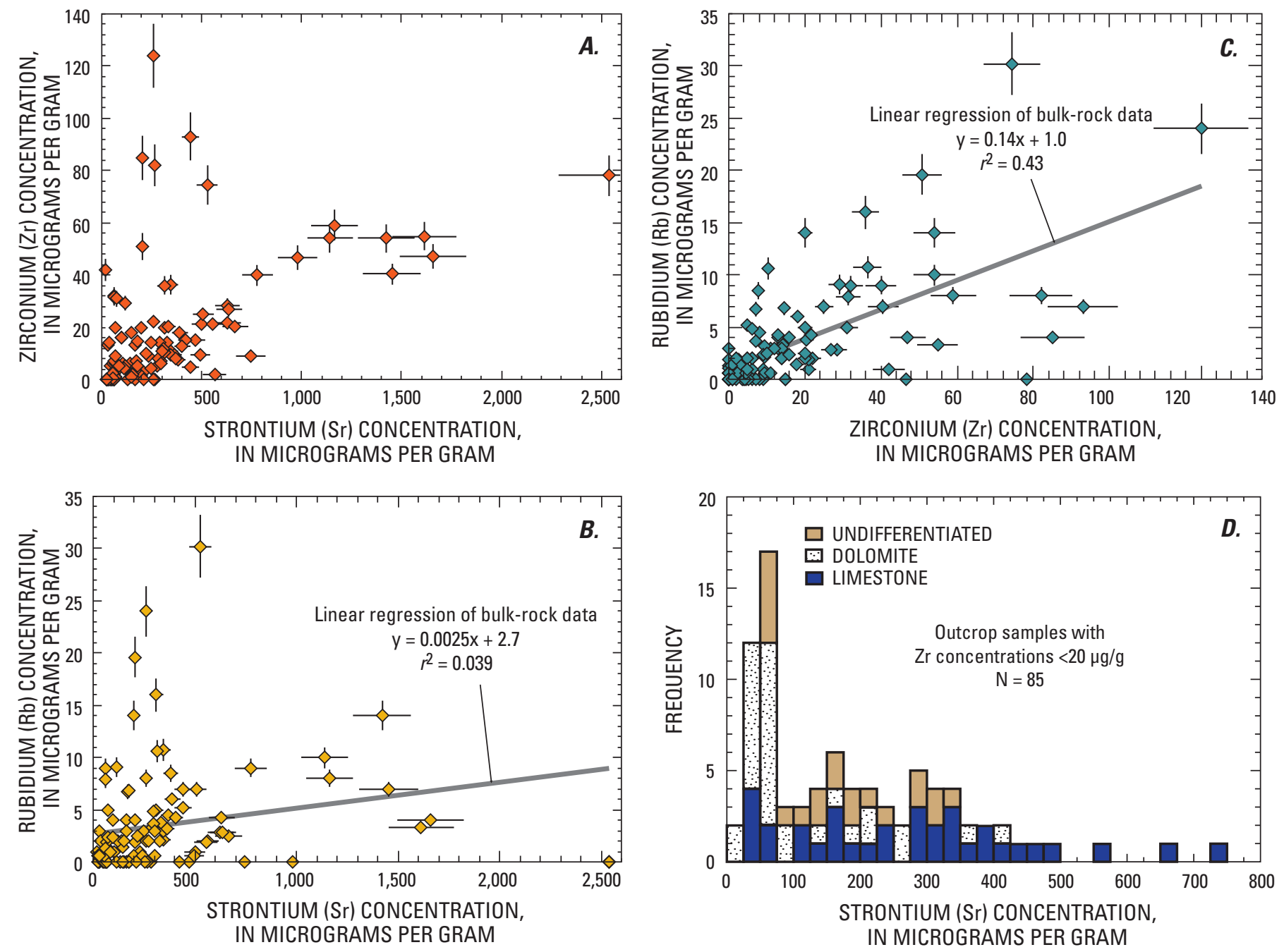

Figure 8. Relation between $(A)$ strontium $(\mathrm{Sr})$ and zirconium $(\mathrm{Zr})$ concentrations, $(B)$ strontium and rubidium $(\mathrm{Rb})$ concentrations, $(C)$ zirconium and rubidium concentrations for bulk-rock outcrop samples, and $(D)$ the frequency distribution of strontium concentrations for bulk-rock outcrop samples with zirconium concentrations less than or equal to 20 micrograms per gram, Nevada Test Site and adjacent areas, Clark, Lincoln, and Nye Counties, Nevada, and Inyo County, California. Error bars represent 2-sigma analytical uncertainty and are shown as 10 percent of the reported concentration value.

\section{Strontium Isotopic Compositions}

Values of ${ }^{87} \mathrm{Sr} /{ }^{86} \mathrm{Sr}$ for the carbonate fractions of borehole (tables 5 and 7 ), and outcrop (table 6) samples range from 0.70720 to 0.72543 and have distributions that are skewed toward radiogenic values (fig. 9). For both sets of samples, approximately 54 percent of the ${ }^{87} \mathrm{Sr} /{ }^{86} \mathrm{Sr}$ analyses are within the range of Paleozoic seawater values between 0.7070 and 0.7092. The remaining analyses have larger ${ }^{87} \mathrm{Sr} /{ }^{86} \mathrm{Sr}$ values, typically between 0.7093 and 0.7150 . Data from Yucca Flat core and cutting samples do not form linear trends on plots comparing ${ }^{87} \mathrm{Sr} /{ }^{86} \mathrm{Sr}$ to reciprocal $\mathrm{Sr}$ concentration (fig. 10A) where binary mixing trends would plot as straight lines.

Therefore, there is no indication that low Sr carbonates were more susceptible to addition of radiogenic $\mathrm{Sr}$ from secondary fluids than high $\mathrm{Sr}$ samples. Furthermore, there are no clear indications that elevated ${ }^{87} \mathrm{Sr} /{ }^{86} \mathrm{Sr}$ values in carbonate fractions are related to the presence of $\mathrm{Rb}$-rich silicate components leached from the samples (fig. 10B). Although the two clayrich samples with the highest $\mathrm{SiO}_{2}$ concentrations also have the highest ${ }^{87} \mathrm{Sr} /{ }^{86} \mathrm{Sr}$ values, similar trends are not present in samples with lower $\mathrm{SiO}_{2}$ concentrations. 
Table 7. Selected trace element concentrations and strontium isotopic compositions $\left({ }^{87} \mathrm{Sr} /{ }^{86} \mathrm{Sr}\right)$ in core samples from boreholes UE-25 a \#3 and UE-25 p \#1, Nevada Test Site, Nye County, Nevada.

[Siliciclastic lithologies for samples from surface to 697.2-m depth in borehole UE-25 a \#3 consist of Mississippian (middle Chester to early Osage stages) Chainman Shale and Gap Wash Formation (Maldonado and others, 1979; Cole and Cashman, 1998). Underlying core is undifferentiated Devonian carbonate (Du). Stratigraphic units for borehole UE-25 p \#1 are from Carr and others (1986). Stratigraphic unit symbols are defined in table 1. Analysis type: WR indicates that strontium isotopic compositions $\left({ }^{87} \mathrm{Sr} r{ }^{86} \mathrm{Sr}\right)$ were determined on whole-rock digestions using concentrated hydrofluoric, nitric, hydrochloric, and sulfuric acids; $\mathrm{HCl}-\mathrm{L}$ indicates that ${ }^{87} \mathrm{Sr} /{ }^{86} \mathrm{Sr}$ values were determined on dilute hydrochloric acid leachates of powdered rock samples. Strontium isotopic compositions also are given in delta notation $\left(\delta^{87} \mathrm{Sr}=\left[{ }^{87} \mathrm{Sr}^{86} \mathrm{Sr}_{\text {sample }}{ }^{187} \mathrm{Sr}^{86} \mathrm{Sr}_{\mathrm{msw}}\right)-1\right] \times 1,000$ and $\delta^{87} \mathrm{Sr}_{\mathrm{t}}=\left[\left({ }^{87} \mathrm{Sr}^{86} \mathrm{Sr}_{\mathrm{sample}}{ }^{87} \mathrm{Sr} /{ }^{86} \mathrm{Sr}_{\mathrm{psw}}\right)-1\right] \times 1,000$, where ${ }^{87} \mathrm{Sr} /{ }^{86} \mathrm{Sr} r_{\mathrm{msw}}$ is the value for modern seawater and ${ }^{87} \mathrm{Sr} r{ }^{86} \mathrm{Sr}_{\mathrm{psw}}$ is the value for paleoseawater at the time of deposition). Abbreviations and symbols: Rb, rubidium; $\mathrm{Sr}$, strontium; Y, yittrium; Zr, zirconium; Nb, Niobium; Ba, barium; La, lanthanum; Ce, cerium; m, meter; \%o, per mil; ND, not determined]

\begin{tabular}{|c|c|c|c|c|c|c|c|c|c|c|c|c|c|c|c|c|}
\hline $\begin{array}{c}\text { Sample } \\
\text { identification } \\
\text { No. }\end{array}$ & Borehole & $\begin{array}{c}\text { Borehole } \\
\text { depth } \\
\text { (m) }\end{array}$ & $\begin{array}{l}\text { Strati- } \\
\text { graphic } \\
\text { unit }\end{array}$ & $\mathbf{R b}$ & $\mathrm{Sr}$ & $\mathbf{Y}$ & $\mathrm{Zr}$ & $\mathrm{Nb}$ & $\mathrm{Ba}$ & La & $\mathrm{Ce}$ & $\begin{array}{c}\text { Analysis } \\
\text { type }\end{array}$ & $\begin{array}{c}{ }^{87} \mathrm{Sr} /{ }^{86} \mathrm{Sr} \\
( \pm 0.000052 \sigma)\end{array}$ & $\begin{array}{c}\delta^{87} \mathbf{S r}, \% 0 \\
( \pm 0.072 \sigma)\end{array}$ & $\begin{array}{c}\delta^{87} \mathbf{S r}_{\mathbf{r}^{\prime}} \\
\% 0\end{array}$ & $\begin{array}{c}\text { Seawater } \\
{ }^{87} \mathrm{Sr}^{866} \mathrm{Sr}_{\mathrm{psw}} \\
\text { used }\end{array}$ \\
\hline UE25a3-324 & UE-25 a \#3 & 98.8 & $\mathrm{Mc} / \mathrm{MDg}$ & 90 & 176 & 41 & 173 & 20 & 182 & ND & ND & WR & .71616 & .81 & 11.4 & .7081 \\
\hline UE25a3-493 & UE-25 a \#3 & 150.4 & $\mathrm{Mc} / \mathrm{MDg}$ & 54 & 91 & 42 & 282 & 20 & & ND & ND & WR & .71795 & 12.34 & 14.0 & .7080 \\
\hline UE25a3-684 & UE-25 a \#3 & 208.4 & $\mathrm{Mc} / \mathrm{MDg}$ & 84 & 177 & 44 & 212 & 21 & 210 & ND & ND & WR & .71539 & 8.73 & 10.5 & .7079 \\
\hline UE25a3-1430 & $\mathrm{UE}-25$ a \#3 & 435.9 & $\mathrm{Mc} / \mathrm{MDg}$ & 78 & 74 & 27 & 117 & 9 & 1,247 & ND & ND & WR & .71633 & 10.05 & 12.2 & .7077 \\
\hline UE25a3-1722 & UE-25 a \#3 & 525.0 & $\mathrm{Mc} / \mathrm{MDg}$ & 146 & 65 & 32 & 151 & 14 & 1,575 & ND & ND & WR & .72022 & 15.54 & 17.4 & .7079 \\
\hline UE25a3-1846 & UE-25 a \#3 & 562.5 & $\mathrm{Mc} / \mathrm{MDg}$ & 61 & 86 & 26 & 137 & 15 & 889 & ND & ND & WR & .72087 & 16.46 & 18.3 & .7080 \\
\hline UE25a3-2093 & UE-25 a \#3 & 637.9 & $\mathrm{Mc} / \mathrm{MDg}$ & 39 & 51 & 15 & 96 & 6 & 394 & ND & ND & WR & .72369 & 20.43 & 22.1 & .7081 \\
\hline UE25a3-2287 & UE-25 a \#3 & 697.2 & $\mathrm{Mc} / \mathrm{MDg}$ & 71 & 131 & 31 & 176 & 7 & 299 & ND & ND & WR & .71700 & 11.00 & 12.5 & .7082 \\
\hline UE25a3-2432 & UE-25 a \#3 & 741.1 & $\mathrm{Du}$ & 2 & 87 & 33 & 6 & 2 & & ND & ND & WR & .71323 & 5.68 & 7.10 & .7082 \\
\hline UE25p 1-5900 & UE-25 p \#1 & $1,798.3$ & $\mathrm{Sr}$ & 3 & 70 & 5 & 15 & 0 & 0 & 23 & 14 & $\mathrm{HCl}-\mathrm{L}$ & .70835 & -1.20 & -.07 & .7084 \\
\hline
\end{tabular}

Values of $\delta^{87} \mathrm{Sr}_{\mathrm{t}}$ calculated with respect to the estimates for Paleozoic seawater ${ }^{87} \mathrm{Sr} /{ }^{86} \mathrm{Sr}$ at the time of deposition range widely from - 1.40 to 24.0 (tables 5-7; fig. 11). Estimates for the original seawater ${ }^{87} \mathrm{Sr} /{ }^{86} \mathrm{Sr}$ were made using the lithostratigraphic age assignments (table 1) and the Paleozoic seawater ${ }^{87} \mathrm{Sr} /{ }^{86} \mathrm{Sr}$ curve of McArthur and others (2001; fig. 3). In many cases, specific age and Paleozoic seawater ${ }^{87} \mathrm{Sr} /{ }^{86} \mathrm{Sr}$ values for individual samples were chosen from the ranges permissible in table 1 to obtain a $\delta^{87} \mathrm{Sr}_{t}$ value closer to 0.0 . Although the Paleozoic seawater ${ }^{87} \mathrm{Sr} /{ }^{86} \mathrm{Sr}$ evolution curve is well established, error bars are not shown on figure 11 because of the difficulty in defining uncertainties for rock ages based on stratigraphic intervals that can span ranges of $10-50 \mathrm{~m} . \mathrm{y}$. or more. Values of $\delta^{87} \mathrm{Sr}_{t}$ close to 0.0 indicate that the carbonate rocks likely have retained their original Paleozoic marine Sr isotopic signatures. In some cases, these data may help corroborate age assignments based on biostratigraphic information (Banner, 2004, p. 167). However, it is preferable to obtain ${ }^{87} \mathrm{Sr} /{ }^{86} \mathrm{Sr}$ data from low-magnesium calcite constituting marine skeletons instead of from bulk rock to avoid post-depositional alteration (Veizer and others, 1999, p. 62). Because all analyses reported here were done on bulk-rock samples, no attempts are made to refine depositional ages. 


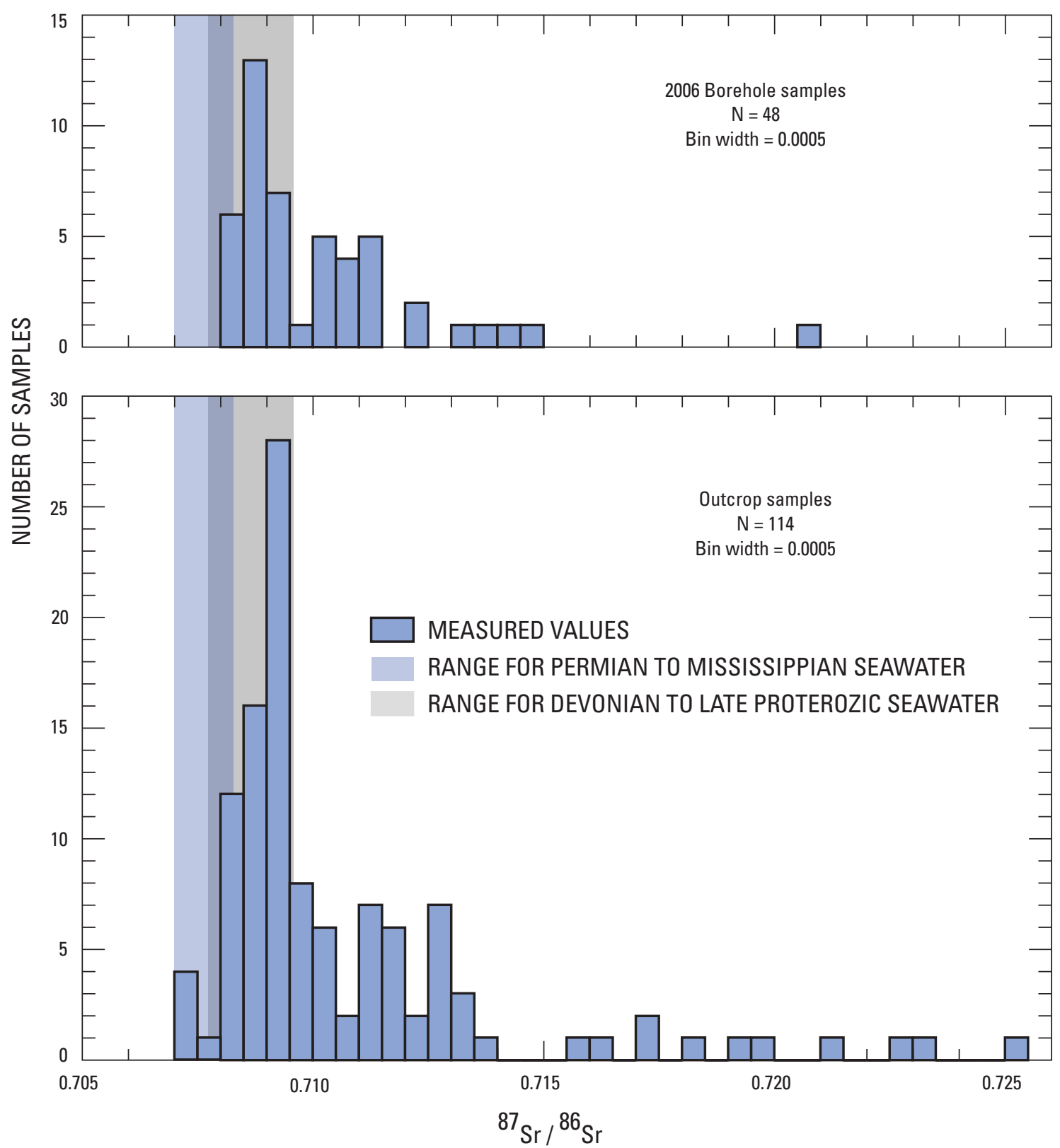

Figure 9. Distribution of strontium isotopic compositions $\left({ }^{87} \mathrm{Sr} r{ }^{86} \mathrm{Sr}\right)$ measured in borehole and outcrop samples, Nevada Test Site and adjacent areas, Clark, Lincoln, and Nye Counties, Nevada, and Inyo County, California. Permian and Pennsylvanian carbonates constituting the upper carbonate aquifer at the Nevada Test Site (fig. 2) typically have lower ${ }^{87} \mathrm{Sr} /{ }^{86} \mathrm{Sr}$ values than the older Paleozoic carbonates constituting the lower carbonate aquifer $\left({ }^{87} \mathrm{Sr} /{ }^{86} \mathrm{Sr}\right.$ ranges from figure 3$)$. 

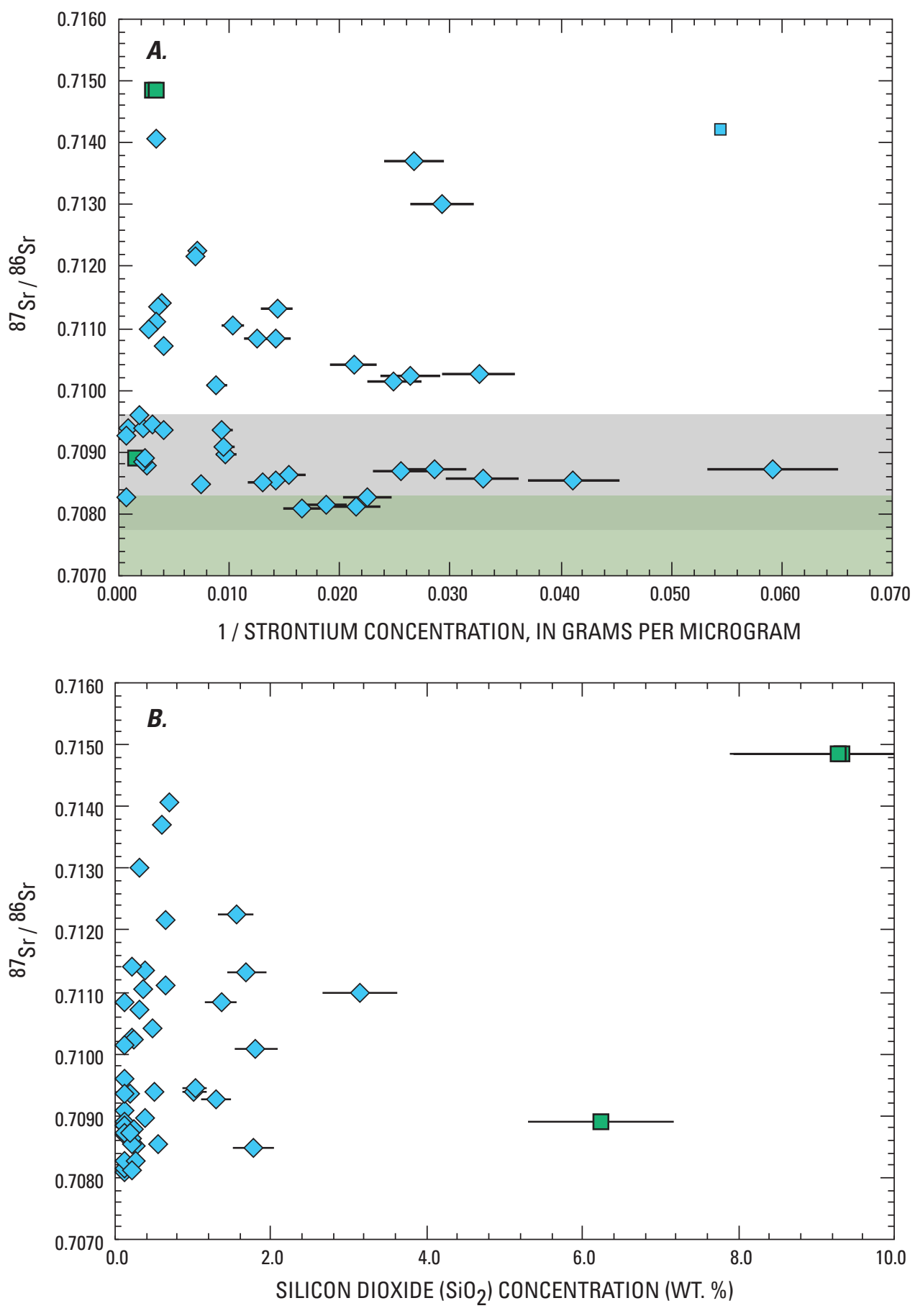

EXPLANATION

$\begin{array}{cl}\diamond \begin{array}{c}\Delta \text { LEACHATES WITH } \mathrm{SiO}_{2}<5 \text { WEIGHT } \\ \text { PERCENT (WT. } \% \text { ) }\end{array} & \text { PERMIAN TO MISSISSIPPIAN SEAWATER }{ }^{87} \mathrm{Sr} /{ }^{86} \mathrm{Sr} \\ \square \text { LEACHATES WITH } \mathrm{SiO}_{2}>5 \text { WT. } \% & \text { DEVONIAN TO NEOPROTEROZOIC SEAWATER }{ }^{87} \mathrm{Sr} /{ }^{86} \mathrm{Sr}\end{array}$

Figure 10. Relation between $(A)$ strontium isotopic compositions $\left({ }^{87} \mathrm{Sr} /{ }^{86} \mathrm{Sr}\right)$ and reciprocal strontium concentrations for acid leachates of borehole samples and $(B){ }^{87} \mathrm{Sr} /{ }^{86} \mathrm{Sr}$ and silicon dioxide $\left(\mathrm{SiO}_{2}\right)$ concentrations for acid leachates of borehole samples, Nevada Test Site, Nye County, Nevada. Error bars represent 2-sigma analytical uncertainty and are shown as 10 percent of the reported concentration value for strontium and 15 percent for $\mathrm{SiO}_{2}$. 

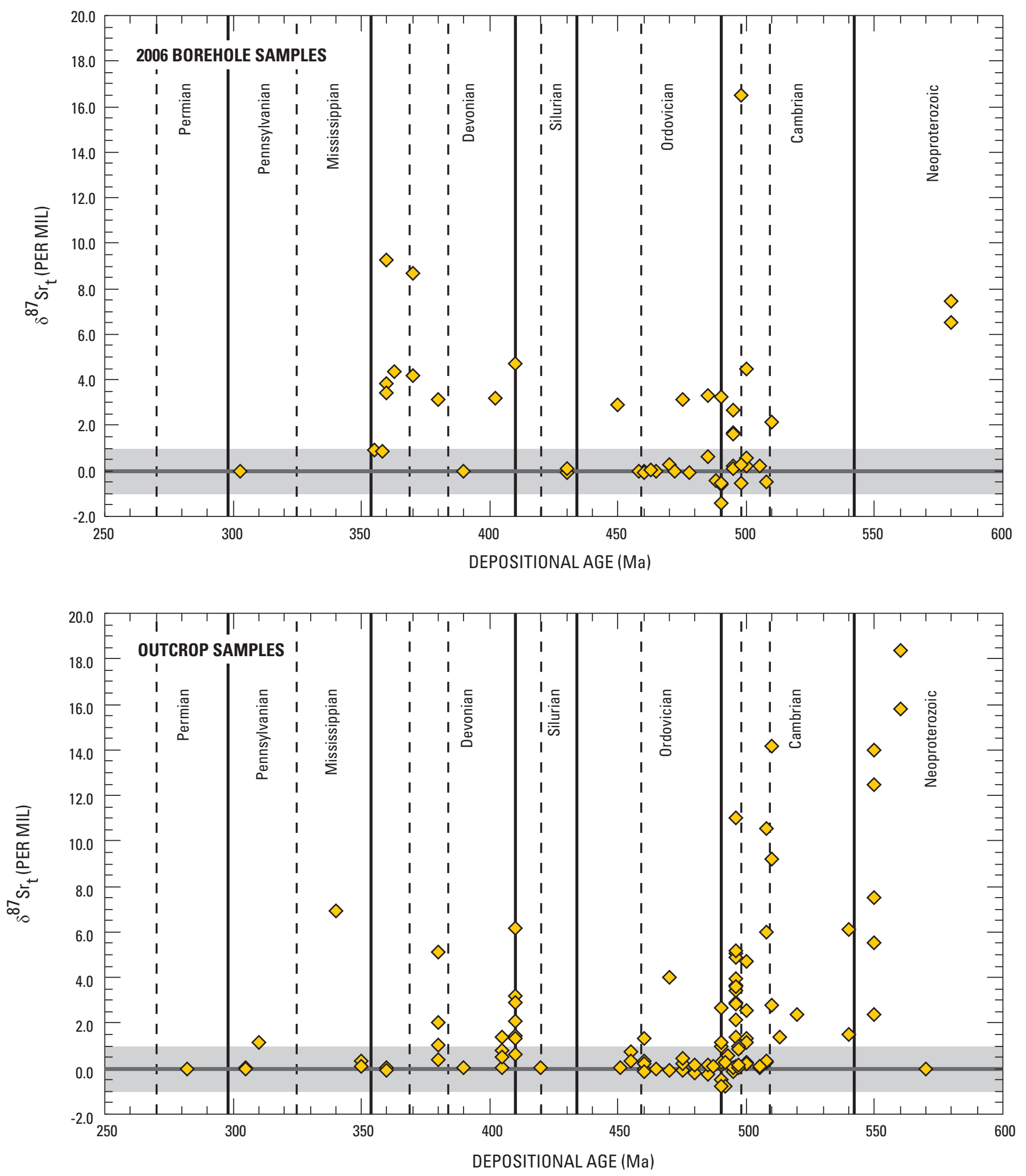

Figure 11. Relation between $\delta^{87} \mathrm{Sr}_{\mathrm{t}^{\prime}}$ and depositional age for acid leachates of borehole and outcrop samples, Nevada Test Site and adjacent areas, Clark, Lincoln, and Nye Counties, Nevada, and Inyo County, California. Data are from tables 5 and 6 . Four analyses with $\delta^{87} \mathrm{Sr}_{\mathrm{t}}$, values between 20.0 and 24.0 are not shown. Shaded band depicts \pm 1 per mil deviation from the assumed paleoseawater value and is shown for reference. 
Samples with measured ${ }^{87} \mathrm{Sr} /{ }^{86} \mathrm{Sr}$ values greater than 0.7093 in tables $5-7$ have undergone obvious postdepositional addition of radiogenic Sr (Peterman and others, 1994). Samples with elevated $\delta^{87} \mathrm{Sr}_{t}$ are present throughout the Paleozoic stratigraphic section in borehole and outcrop samples (fig. 11), indicating that ${ }^{87} \mathrm{Sr} /{ }^{86} \mathrm{Sr}$ alteration was not restricted to rocks formed during a narrow interval of Paleozoic time. Peterman and others (1994) documented that Paleozoic carbonates at Bare Mountain have elevated $\delta^{87} \mathrm{Sr}_{\mathrm{t}}$ values compared to samples from the Striped Hills, Specter Range, Spring Mountains, and mountain ranges east of the NTS (fig. 12). These anomalous $\delta^{87} \mathrm{Sr}_{\mathrm{t}}$ values were obtained on samples from mineralized areas including the Stirling Gold Mine on the eastern flank of Bare Mountain. Peterman and others $(1994$, p. 1,321) postulated that hydrothermal mineralization was associated with Tertiary volcanic activity and involved localized plumes of thermal solutions which introduced radiogenic Sr derived from the Precambrian basement into carbonate rocks present at shallower crustal levels. Therefore, the spatial distribution of Paleozoic carbonate rocks with nonmarine ${ }^{87} \mathrm{Sr} /{ }^{86} \mathrm{Sr}$ compositions at and around the NTS (fig. 12) could be related to major crustal structures that provide fluid pathways and magmatic activity that provided thermal sources.

Paleozoic carbonates present in the northeastern part of the NTS have the potential to be affected by Tertiary magmatic activity constituting the southwestern Nevada volcanic field centered at Timber Mountain and Pahute Mesa (Byers and others, 1989; Sawyer and others, 1994). Results from this study indicate that Paleozoic limestone and dolomite beneath Rainier Mesa, Yucca Flat, and Frenchman Flat tend to have $\delta^{87} \mathrm{Sr}_{\mathrm{t}}$ values intermediately between those measured at Bare Mountain and ranges southeast of the NTS (fig. 1; fig. 12A). Carbonate rocks with elevated $\delta^{87} \mathrm{Sr}_{\mathrm{t}}$ are present near the bottom of borehole UE-15d (Rainstorm Member of the Johnnie Formation or Noonday Dolomite) underlying a thick section of Neoproterozoic siliciclastic rocks constituting the Lower Clastic Confining Unit in northern Yucca Flat. In western Yucca Flat and the Calico Hills, boreholes ER-16-1, ER-12-1, ER-6-2, UE-16d, and UE-25 a\#3 penetrate thick sections of Eleana Formation, Gap Wash Formation, and Chainman Shale consisting of abundant litharenite, siltstone, and shale (fig. 1; fig. 12B). Clay minerals with elevated
$\mathrm{Rb} / \mathrm{Sr}$ in these siliciclastic rocks constituting the upper clastic confining unit are a possible source for radiogenic $\mathrm{Sr}$ in carbonate rocks present in these boreholes. Rocks constituting the upper clastic confining unit are not present in eastern Yucca Flat or Frenchman Flat, and carbonates from ER-3-1, ER-7-1, ER-6-1\#2, and HTH \#3 have retained their Paleozoic seawater signatures (fig. 12B). Other boreholes having LCA rocks directly underlying Tertiary volcanic or alluvial rocks may or may not have Paleozoic carbonate with elevated $\delta^{87} \mathrm{Sr}_{\mathrm{t}}$ values.

In several cases, $\mathrm{Sr}$ isotopic compositions were obtained from macroscopically unaltered and altered core samples [Army 1(859) and Army 1(862), TW-C(1458) and TW-C(1463.5)]. For both pairs, samples with brecciated textures, iron staining, and clay mineralization (table 3) had higher ${ }^{87} \mathrm{Sr} /{ }^{86} \mathrm{Sr}$ values than the sample lacking obvious alteration (table 5). The difference is most dramatic for leachates of samples Army 1(859) and Army 1(862) where the highly altered dolomite has $\mathrm{Sr}$ concentrations more than twice the value present in the unaltered dolomite and a $\delta^{87} \mathrm{Sr}_{t}$ value of 3.84 compared to the near seawater value of -0.06 in the unaltered dolomite. Differences are not as large between samples TW-C(1458) and TW-C(1463.5) with negligibly higher $\mathrm{Sr}$ concentrations in the altered limestone (261 compared to $251 \mu \mathrm{g} / \mathrm{g}$ ) and $\delta^{87} \mathrm{Sr}_{\mathrm{t}}$ values of 2.82 compared to 1.87 . However, addition of radiogenic ${ }^{87} \mathrm{Sr}$ is not always accompanied by obvious evidence for secondary alteration. Samples UE15d(5994), ER12-4(2580), ER6-2(1830), and ER5-3\#2(4780) have $\delta^{87} \mathrm{Sr}_{\mathrm{t}}$ values between 3.45 and 5.78, but do not show obvious macroscopic evidence of alteration.

Finally, one pair of samples representing unaltered host dolomite [Army 1(982)A] and coarse secondary dolomite spar [Army 1(982)B] filling a cross-cutting vein were analyzed to investigate the degree of isotopic disequilibrium between the two materials. Leachates of both samples have similar Sr concentrations (30.7 compared to $37.9 \mu \mathrm{g} / \mathrm{g}$; table 5) and analytically indistinguishable ${ }^{87} \mathrm{Sr} /{ }^{86} \mathrm{Sr}$ values $(0.71027$ compared to 0.71023). These data are consistent with a local source of Sr for the younger dolomite spar. Although the age and petrogenesis of the secondary dolomite vein are not known, the thick filling of dense, coarsely crystalline dolomite is not likely to have formed under modern ground-water flow conditions. 


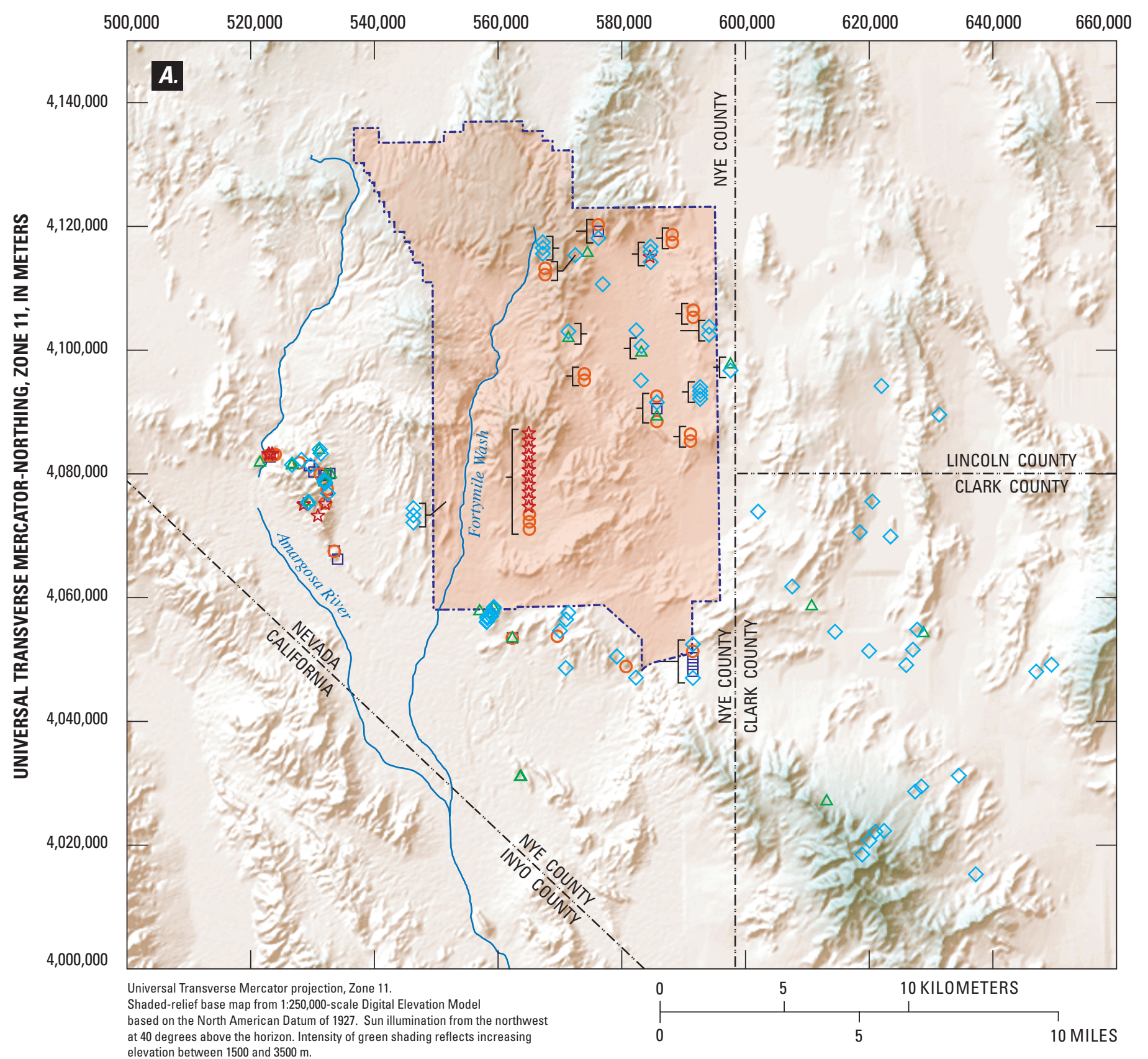

UNIVERSAL TRANSVERSE MERCATOR-EASTING, ZONE 11, IN METERS

\section{EXPLANATION}

- - - Nevada Test Site boundary

$\begin{array}{cc}\delta^{87} \mathrm{Sr}_{\mathrm{t}} \text { values (in per } \\ \text { from seawater at } \\ \diamond \quad-0.5 \text { to } 0.5 \\ \Delta \quad 0.5 \text { to } 1.5 \\ \square & 1.5 \text { to } 3.0 \\ \bigcirc & 3.0 \text { to } 10.0 \\ \star & 10.0 \text { to } 25.0\end{array}$

Figure 12. Spatial distribution of $\delta^{87} \mathrm{Sr}_{\mathrm{t}^{\prime}}$ values for borehole and outcrop samples $(A)$ from the Nevada Test Site vicinity, and $(B)$ in and adjacent to the eastern part of the Nevada Test Site, Clark, Lincoln, and Nye Counties, Nevada, and Inyo County, California. Multiple samples from boreholes are shown as vertical arrays in order of depth within borehole (not to scale) with a leader indicating borehole location. 


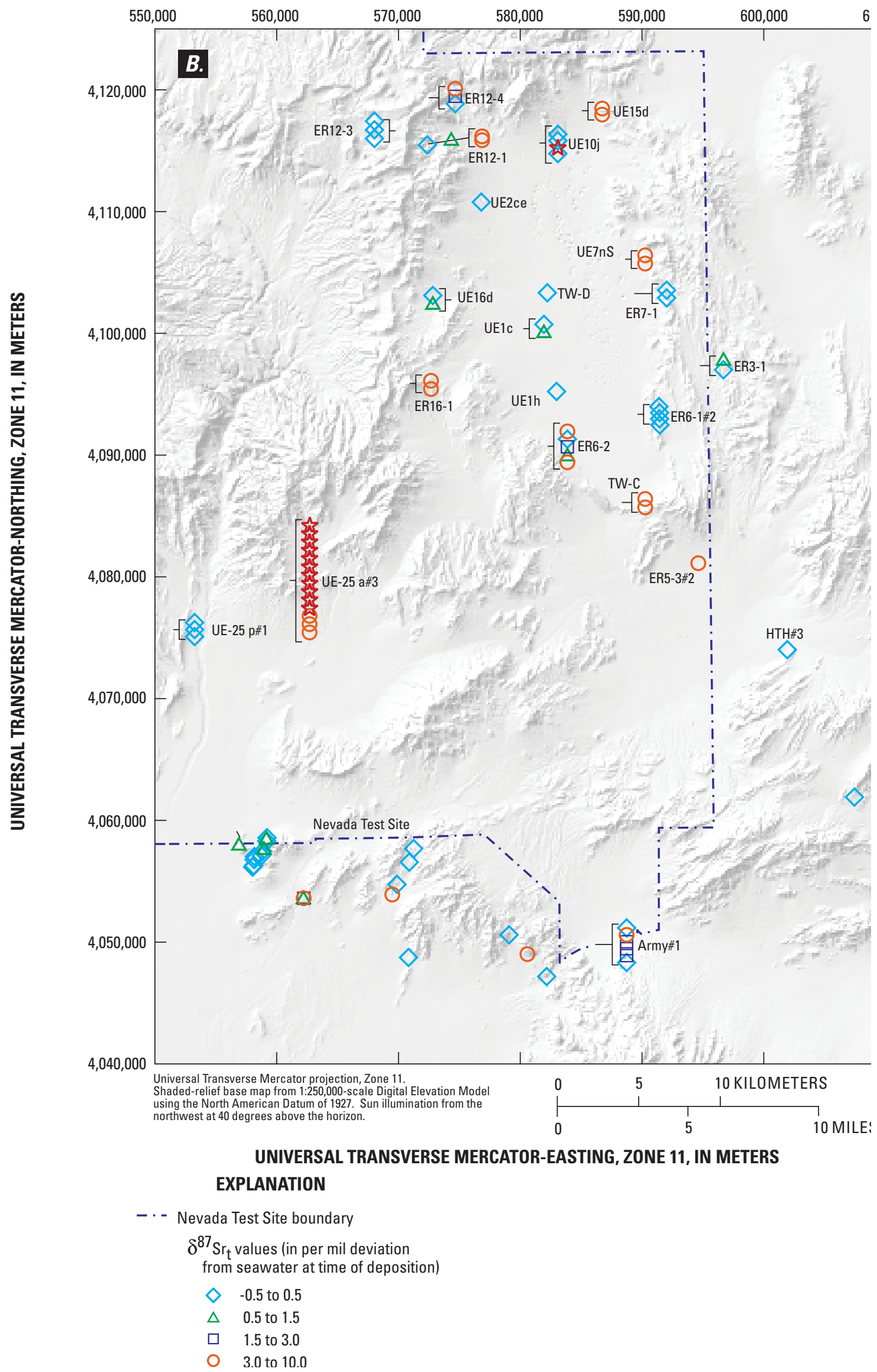

Figure 12. Continued. 


\section{Summary and Conclusions}

To contribute to a more accurate understanding of regional ground-water flow beneath the Nevada Test Site vicinity in southern Nevada using ${ }^{87} \mathrm{Sr} r{ }^{86} \mathrm{Sr}$ values, chemical and strontium isotope data are reported for rock samples representing water-producing horizons in the lower carbonate aquifer, as well as in the upper carbonate aquifer and lower clastic confining unit. Samples obtained in 2006 include core and cutting fragments from 20 boreholes located around Yucca Flat, Frenchman Flat, Rainier Mesa, and Mercury Valley. Partial digestions using dilute nitric acid were used to quantify $\mathrm{MgO}, \mathrm{CaO}, \mathrm{SiO}_{2}, \mathrm{Al}_{2} \mathrm{O}_{3}, \mathrm{MnO}, \mathrm{Rb}, \mathrm{Sr}$, Th, and $\mathrm{U}$ concentrations in carbonate fractions, which constituted more than 90 percent of most rocks. Small amounts of $\mathrm{SiO}_{2}$ and $\mathrm{Al}_{2} \mathrm{O}_{3}$ in leachates are evidence that clay minerals may be present in many carbonate samples. Three samples containing visible shale or volcanic components have $\mathrm{SiO}_{2}$ concentrations as high as 5-10 weight percent. Dolomites have median $\mathrm{Sr}$ concentrations of 46.5 micrograms per gram $(\mu \mathrm{g} / \mathrm{g})$, substantially lower than the median value of 384.5 $\mu \mathrm{g} / \mathrm{g}$ for limestones. Because both rock types have similar $\mathrm{Rb}$ concentrations, dolomites tend to have higher $\mathrm{Rb} / \mathrm{Sr}$ ratios. However, these values are low enough in most samples so that increases in ${ }^{87} \mathrm{Sr} /{ }^{86} \mathrm{Sr}$ caused by decay of ${ }^{87} \mathrm{Rb}$ are not substantial. Values of ${ }^{87} \mathrm{Sr} /{ }^{86} \mathrm{Sr}$ analyzed from the same leachates of dolomites and limestones range from 0.70809 to 0.72089 and show no dependency on Sr concentrations.

In addition to subsurface samples from NTS boreholes, 114 samples from outcrop, road cut, and underground exposures of Paleozoic carbonates were collected and analyzed in the early-to-mid 1990s. These samples are from locations to the west, south, and east of the NTS including sites in the Funeral Mountains, Bare Mountain, Striped Hills, Specter Range, Spring Mountains, and ranges east of the NTS. Although results for these samples were discussed earlier (Peterman and others, 1994), the data have not been published. Like the borehole samples, dolomite tends to have lower bulk-rock Sr concentrations (typically $22-96 \mu \mathrm{g} / \mathrm{g}$ ), whereas limestone tends to have higher $\mathrm{Sr}$ concentrations that commonly range up to about $500 \mu \mathrm{g} / \mathrm{g}$.

The distribution of $\mathrm{Sr}$ isotopic compositions from carbonate fractions of borehole and outcrop samples are skewed toward higher ${ }^{87} \mathrm{Sr} /{ }^{86} \mathrm{Sr}$ values. Many samples have ${ }^{87} \mathrm{Sr} /{ }^{86} \mathrm{Sr}$ values consistent with Paleozoic seawater ${ }^{87} \mathrm{Sr} /{ }^{86} \mathrm{Sr}$ values ranging from about 0.7070 to 0.7092 . Samples with ${ }^{87} \mathrm{Sr} /{ }^{86} \mathrm{Sr}$ values greater than 0.7093 have experienced postdepositional modification, which was caused by interaction with fluids containing radiogenic Sr. Carbonate rocks with modified ${ }^{87} \mathrm{Sr} /{ }^{86} \mathrm{Sr}$ values are present throughout the stratigraphic section. However, rocks with elevated ${ }^{87} \mathrm{Sr} /{ }^{86} \mathrm{Sr}$ are most common around areas of known mineralization at Bare Mountain, and in western Yucca Flat where the upper clastic confining unit may contribute radiogenic Sr from clay minerals with elevated $\mathrm{Rb} / \mathrm{Sr}$. Paleozoic carbonate rocks with non-marine ${ }^{87} \mathrm{Sr} /{ }^{86} \mathrm{Sr}$ signatures may show mineralogical or textural evidence of alteration; however, some samples with elevated ${ }^{87} \mathrm{Sr} /{ }^{86} \mathrm{Sr}$ show no obvious signs of post-depositional modification. The ranges of $\mathrm{Sr}$ concentrations and ${ }^{87} \mathrm{Sr} /{ }^{86} \mathrm{Sr}$ values presented in this report can be used in hydrochemical modeling efforts to represent the composition of carbonate rock dissolved during regional ground-water flow.

\section{Acknowledgments}

Leigh Justet and Gerald E. Magner helped collect core and cutting samples archived at the U.S. Geological Survey Core Library and Data Center in Mercury, Nevada. Richard W. Spengler, Michael D. Carr, Susan A. Monsen, John N. Aleinikoff, Fran Singer, and Beth Widman helped collect and describe outcrop samples. Shannon Mahan helped make strontium isotope measurements on outcrop samples analyzed in the early 1990's. James C. Cole provided outcrop samples from parts of the Nevada Test Site and Nellis Air Force Base that were off limits to the authors. Technical reviews by Leigh Justet and James C. Cole improved the quality of the manuscript and stratigraphic unit assignments.

\section{References Cited}

Banner, J.L., 2004, Radiogenic isotopes: systematics and applications to earth surface processes and chemical stratigraphy: Earth-Science Reviews, v. 65, p. 141-194.

Banner, J.L., Wasserburg, G.J., Dobson, P.F., Carpenter, A.B., and Moore, C.H., 1989, Isotopic and trace element constraints on the origin and evolution of saline ground waters from central Missouri: Geochimica et Cosmochimica Acta, v. 53, p. 383-398.

Barnes, Harley, and Christiansen, R.L., 1967, Cambrian and Precambrian rocks of the Groom District, Nevada, southern Great Basin: U.S. Geological Survey Bulletin 1244-G, 34 p.

Burchfiel, B.C., 1964, Precambrian and Paleozoic stratigraphy of Specter Range quadrangle, Nye County, Nevada: American Association of Petroleum Geologists Bulletin, v. 48, p. 43-67.

Burke, W.H., Denison, R.E., Hetherington, E.A., Koepnick, R.B., Nelson, N.F., and Otto, J.B., 1982, Variation of seawater ${ }^{87} \mathrm{Sr} /{ }^{86} \mathrm{Sr}$ throughout Phanerozoic time: Geology, v. 10, p. 516-519.

Byers, F.M., Jr., Carr, W.J., and Orkild, P.P., 1989, Volcanic centers of southwestern Nevada - Evolution of understanding, 1960-1988: Journal of Geophysical Research, v. 94, p. 5,908-5,924. 
Carr, M.D., Waddel, S.J., Vick, G.S., Stock, J.M., Monsen, S.A., Harris, A.G., Cork, B.W., and Byers Jr., F.M., 1986, Geology of drill hole UE25p\#1: A test hole into preTertiary rocks near Yucca Mountain, southern Nevada: U.S. Geological Survey Open-File Report 86-175, 87 p.

Chaudhuri, S., Broedel, V., and Clauer, N., 1987, Strontium isotopic evolution of oil-field waters from carbonate reservoir rocks in Brindley field, central Kansas, U.S.A.: Geochimica et Cosmochimica Acta, v. 51, p. 45-53.

Cole, J.C., and Cashman, P.H., 1998, Geologic map of Paleozoic rocks in the Calico Hills, Nevada Test Site, southern Nevada: U.S. Geological Survey Open-File Report 98-101, 19 p.

Cole, J.C., and Cashman, P.H., 1999, Structural relationships of pre-Tertiary rocks in the Nevada Test Site region, southern Nevada: U.S. Geological Survey Professional Paper 1607, 39 p.

Cole, J.C., Harris, A.G., and Wahl, R.R., 1997, Sub-crop geologic map of pre-Tertiary rocks in the Yucca Flat and northern Frenchman Flat areas, Nevada Test Site, southern Nevada: U.S. Geological Survey Open-File Report 97-678, $24 \mathrm{p}$.

Elderfield, H., 1986, Strontium isotope stratigraphy: Palaeogeography, Palaeoclimatology, Palaeoecology, v. 57, p. 71-90.

Farnham, I.M., Rose, T.P., Kwicklis, E.M., Hershey, R.L., and Paces, J.B., 2006, Geochemical and isotopic evaluation of groundwater movement in corrective action unit 97: Yucca Flat/Climax Mine, Nevada Test Site, Nevada: Stoller-Navarro Joint Venture, Report S-N/99205-070 to DOE, Stoller-Navarro Joint Venture, Las Vegas, Nevada, 283 p. Accessed at http://www.osti.gov/bridge/servlets/ purl/877252-NKdprN/877252.PDF on March 14, 2007.

Faure, Gunter, 1986, Principles of isotope geology, (2nd. ed.): John Wiley \& Sons, New York, 589 p.

Faure, Gunter, and Mensing, T.M., 2005, Isotopes: Principles and applications (3rd ed.): Hoboken, New Jersey, John Wiley \& Sons, Inc., 897 p.

Frost, C.D., and Toner, R.N., 2004, Strontium isotopic identification of water-rock interaction and ground-water mixing: Groundwater, v. 42, p. 418-432.

Gaines, R.V., Skinner, H.C.W., Foord, E.E., Mason, B., and Rosenzweig, A., 1997, Dana's new mineralogy: New York, John Wiley \& Sons, Inc., 1,819 p.
Hershey, R.L., Thomas, J.M., Rose, T.P., Paces, J.B., Farnham, I.M., and Benedict Jr., F.C., 2005, Evaluation groundwater movement in the Frenchman Flat CAU using geochemical and isotopic analysis: Desert Research Institute Publication No. 45207, DOE/NV/13609-36: Prepared for the U.S. Department of Energy, National Nuclear Security Administration, Nevada Site Office, Las Vegas, Nevada: Desert Research Institute, 75 p., accessed March 14, 2007, at http://www.osti.gov/bridge/servlets/purl/839138F6w01Y/native/839138.pdf.

Johnson, T.M., and DePaolo, D.J., 1994, Interpretation of isotopic data in groundwater-rock systems: Model development and application to $\mathrm{Sr}$ isotope data from Yucca Mountain: Water Resources Research, v. 30, p. 1,571-1,587.

Johnson, T.M., and DePaolo, D.J., 1997, Rapid exchange effects on isotope ratios in groundwater systems 1 . Development of a transport-dissolution-exchange model: Water Resources Research, v. 33, p. 187-195.

Johnson, T.M., Roback, R.C., McLing, T.L., Bullen, T.D., DePaolo D.J., Doughty, C., Hunt, R.J., Smith, R.W., Cecil, L.D., and Murrell, M.T., 2000, Groundwater "fast paths" in the Snake River Plain aquifer: Radiogenic isotope ratios as natural groundwater tracers: Geology, v. 28, p. 871-874.

Laczniak, R.J., Cole, J.C., Sawyer, D.A., and Trudeau, D.A., 1996, Summary of hydrogeologic controls on ground-water flow at the Nevada Test Site, Nye County, Nevada: U.S. Geological Survey Water-Resources Investigations Report 96-4109, 59 p.

Ludwig, K.R., Halley, R.B., Simmons, K.R., and Peterman, Z.E., 1988, Strontium-isotope stratigraphy of Enewetak Atoll: Geology, v. 16, p. 173-177.

Maldonado, Florian, Muller, D.C., and Morrison, J.N., 1979, Preliminary geologic and geophysical data of the UE25a3 exploratory drill hole, Nevada Test Site, Nevada: U.S. Geological Survey-1543-6, 43 p.

McArthur, J.M., Howarth, R.J., and Bailey, T.R., 2001, Strontium isotope stratigraphy: LOWESS Version 3: Best fit to the marine Sr-isotope curve for 0-509 Ma and accompanying look-up table for deriving numerical age: Journal of Geology, v. 109, p. 155-170.

McKelvey, B.A., and Orians, K.J., 1993, Dissolved zirconium in the North Pacific Ocean: Geochimica et Cosmochimica Acta, v. 57, p. 3,801-3,805. 
McKenna, C.M., McNutt, R.H., and Frape, S.K., 1992, Lead and strontium isotopic data on brines from the Michigan basin, Ontario and Michigan in, Karaka, Y.K., and Maest, A.S., (eds.), Water-Rock Interaction: Proceedings of the 7th International Symposium on Water-Rock Interaction, Park City, Utah, July 13-18, 1992, p. 971-974.

McNutt, R.H., 2000, Strontium isotopes in Cook, P.G., and Herczeg, A.L., (eds.), Environmental tracers in subsurface hydrology: Boston, Kluwer Academic Publishers, p. 233-260.

Monsen, S.A., Carr, M.D., Reheis, M.C., and Orkild, P.P., 1992, Geologic map of Bare Mountain, Nye County, Nevada: U.S. Geological Survey MiscellaneousInvestigations Series Map I-2201, 6 p., 1 sheet.

Page, W.R., Lundstrom, S.C., Harris, A.G., Langenheim, V.E., Workman, J.B., Mahan, S.A., Paces, J.B., Dixon, G.L., Rowley, P.D., Burchfiel, B.C., Bell, J.W., and Smith, E.I., 2005, Geologic and geophysical maps of the Las Vegas 30' x 60' quadrangle, Clark and Nye Counties, Nevada, and Inyo County, California: U.S. Geological Survey ScientificInvestigations Map 2814, 58 p., 2 sheets.

Peterman, Z.E., Hedge, C.E., and Tourtelot, H.A., 1970, Isotopic composition of strontium in seawater throughout Phanerozoic time: Geochimica et Cosmochimica Acta, v. 34, p. 105-120.

Peterman, Z.E., and Stuckless, J.S., 1992, Application of strontium and other radiogenic tracer isotopes to paleohydrologic studies in Paleohydrological methods and their applications: Proceedings of an NEA Workshop, Paris, France, November 9-10, 1992, Nuclear Energy Agency, Organization for Economic Co-Operation and Development, p. 59-84.

Peterman, Z.E., Stuckless, J.S., Mahan, S.A., Marshall, B.D., Gutentag, E.D., and Downey, J.S., 1992, Strontium isotope characterization of the Ash Meadows ground-water system, southern Nevada, USA in Karaka, Y.K., and Maest, A.S., (eds.), Water-Rock Interaction: Proceedings of the 7th International Symposium on Water-Rock Interaction, Park City, Utah, July 13-18, 1992, p. 825-829.

Peterman, Z.E., Widmann, B.L., Marshall, B.D., Aleinikoff, J.N., Futa, K., and Mahan, S.A., 1994, Isotopic tracers of gold deposition in Paleozoic limestones, southern Nevada: Proceedings of the Fifth Annual International Conference, High-Level Radioactive Waste Management, Las Vegas, Nevada, May 22-26, 1994, American Nuclear Society, LaGrange Park, Illinois, p. 1316-1323.
Poole, F.G., 1974, Flysch deposits of the Antler Foreland Basin, western United States in Dickinson, W.R., (ed.), Tectonics and Sedimentation: Society of Economic Paleontologists and Mineralogists Special Publication 22, p. 58-82.

Rose, T.P., Benedict Jr., F.C., Thomas, J.M., Sicke, W.S., Hershey, R.L., Paces, J.B., Farnham, I.M., and Peterman, Z.E., 2006, Geochemical data analysis and interpretation of the Pahute Mesa-Oasis Valley Groundwater Flow System, Nye County, Nevada, August 2002: U.S. Department of Energy, Lawrence Livermore National Laboratory Report UCRL-TR-224559, 137 p..

Sawyer, D.A., Fleck R.J., Lanphere, M.A., Warren, R.G., and Broxton, D.E., 1994, Episodic volcanism in the Miocene southwest Nevada volcanic field-Revised stratigraphic framework, ${ }^{40} \mathrm{Ar} /{ }^{39} \mathrm{Ar}$ geochronology, and implications for magmatism and extension. Geological Society of America Bulletin, v. 106, p. 1,304-1,318.

Slate, J.L., Berry, M.E., Rowley, P.D., Fridrich, C.J., Morgan, K.S., Workman, J.B., Young, O.D., Dixon, G.L., Williams, V.S., McKee, E.H., Ponce, D.A., Hildenbrand, T.G., Swadley, W.C., Lundstrom, S.C., Ekren, E.B., Warren, R.G., Cole, J.C., Fleck, R.J., Lanphere, M.A., Sawyer, D.A., Minor, S.A., Grunwald, D.J., Laczniak, R.J., Menges, C.M., Yount, J.C., and Jayko, A.S., 1999, Digital geologic map of the Nevada Test Site and vicinity, Nye, Lincoln, and Clark Counties, Nevada, and Inyo County, California: U.S. Geological Survey Open-File Report 99-554-A, 56 p.

Stewart, J.H., and Poole, F.G., 1974, Lower Paleozoic and uppermost Precambrian Cordilleran miogeosyncline, Great Basin, western United States in Dickinson, W.R., (ed.), Tectonics and Sedimentation: Society of Economic Paleontologists and Mineralogists Special Publication 22, p. 28-57.

Thomas, J.M., Benedict Jr., F.C., Rose, T.P., Hershey, R.L., Paces, J.B., Peterman, Z.E., Farnham, I.M., Johannesson, K.H., Singh, A.K., Stetzenbach, K.J., Hudson, G.B., Kenneally, J.M., Eaton, G.F., and Smith, D.K., 2002, Geochemical and isotopic interpretations of groundwater flow in the Oasis Valley Flow System, Southern Nevada: Desert Research Institute Publication No. 45, 190 p.

Trexler Jr. J.H., Cashman, P.H., Cole, J.C., Snyder, W.S., Tosdal, R.M., and Davydov, V.I., 2003, Widespread effects of middle Mississippian deformation in the Great Basin of western North America: Geological Society of America Bulletin, v. 115, p. 1,278-1,288. 


\section{Strontium Isotopic Composition of Paleozoic Carbonate Rocks, Nevada Test Site Vicinity, Nevada and California}

Trexler Jr., J.H., Cole, J.C., and Cashman, P.H., 1996, Middle Devonian-Mississippian stratigraphy on and near the Nevada Test Site-Implications for hydrocarbon potential: American Association of Petroleum Geologists Bulletin, v. 80 , p. $1,736-1,762$.

U.S. Department of Energy, 1991, Environmental restoration and waste management-Site-specific plan for fiscal years 1992-1996: U.S. Department of Energy, Nevada Operations Office, unnumbered report, $274 \mathrm{p}$.

U.S. Geological Survey, 2006, Lithologic-description database (webpage and spreadsheet nts_lth_dsc_061127.xls), accessed January 18, 2007, at http://nevada.usgs.gov/ mercury/core.html
Veizer, J., Ala, D., Azmy, K., Bruckschen, P., Buhl, D., Bruhn, F., Carden, G.A.F., Diener, A., Ebneth, S., Godderis, Y., Jasper, T., Korte, C., Pawellek, F., Podlaha, O., and Strauss, H., $1999,{ }^{87} \mathrm{Sr} /{ }^{86} \mathrm{Sr}, \delta^{13} \mathrm{C}$ and $\delta^{18} \mathrm{O}$ evolution of Phanerozoic seawater: Chemical Geology, v. 161, p. 59-88.

Winograd, I.J., and Thordarson, W., 1975, Hydrogeologic hydrochemical framework, southcentral Great Basin, Nevada-California, with special reference to the Nevada Test Site: U.S. Geological Survey Professional Paper 712-C, 126 p.

Young, G.C., and Laurie, J.R., 1996, An Australian Phanerozic timescale: Oxford University Press, England, 292 p. 
For more information contact:

Director, Nevada Water Science Center

U.S. Geological Survey

2730 N. Deer Run Road

Carson City, Nevada 89701

http://nevada.usgs.gov 


\section{d क}

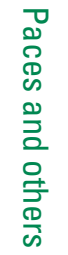

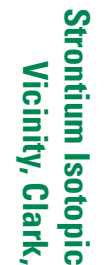

동응 을

흘

청ㅇ

ㅇํㅇ

촐.

क्ष.

공 웧

을 을

)

를

총

을

言

ช

을. 홍

क)

隶

응 